\title{
PHOTON DOSE RATES FROM SPENT FUEL ASSEMBLIES \\ WITH RELATION TO SELF-PROTECTION (Rev. 1)
}

\section{RECEIVED

R. B. Pond and J. E. Matos

RERTR Program

Argonne National Laboratory

Argonne, IL 60439

February 1996

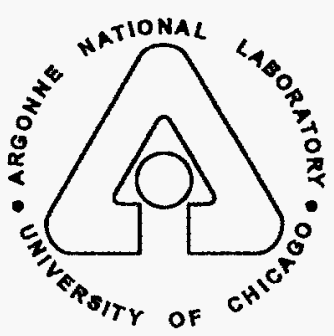

ARGONNE NATIONAL LABORATORY, ARGONNE, ILLINOIS

Operated by The University of Chicago

for the United States Department of Energy under Contract No. W-31-109-Eng-38. 
Argonne National Laboratory, with facilities in the states of Ulinois and Idaho, is owned by the United States government, and operatad by the University of Chicago under the provisions of a contract with the Department of Energy.

\section{DISCLAIMER}

This report was prepared as an account of work sponsored by an agency of the United States Government. Neither the United States Government ror ariy agency thereof, nor any of their employees, making any warranty. express or implied, or assumies any legal liability or responsibility for the accuracy, completeness, or usefulness of any information, apparatus, product or process disclosed, or represents that its use would not infringe privately owned rights. Reference herein to any specific commercial product, process, or service by trade name, trademark, manufacturer, or otherwise, does not necessarily constitute or imply its endorsement, recommendations, or favorings by the United States Guvernment or any agency thereof The views and opinions of authors expressed herein do not necessarily state or reflect those of the United States Government or any agency thereof.

Available from the Reduced Enrichment for Research and Test Reactor (RERTR) Program

Argonne National Laboratory

9700 South Cass Avenue

Argonne, IL 60439-48411 


\title{
PHOTON DOSE RATES FROM SPENT FUEL ASSEMBLIES \\ WITH RELATION TO SELF-PROTECTION (Rev. 1)
}

\author{
R. B. Pond and J. E. Matos \\ RERTR Program \\ Argonne National Laboratory \\ Argonne, IL 60439
}

February 1996

\begin{abstract}
DISCLAIMER
This report was prepared as an account of work sponsored by an agency of the United States Government. Neither the United States Government nor any agency thereof, nor any of their employees, makes any warranty, express or implied, or assumes any legal liability or responsibility for the accuracy, completeness, or usefulness of any information, apparatus, product, or process disclosed, or represents that its use would not infringe privately owned rights. Reference herein to any specific commercial product, process, or service by trade name, trademark, manufacturer, or otherwise does not necessarily constitute or imply its endorsement, recommendation, or favoring by the United States Government or any agency thereof. The views and opinions of authors expressed herein do not necessarily state or reflect those of the United States Government or any agency thereof.
\end{abstract}

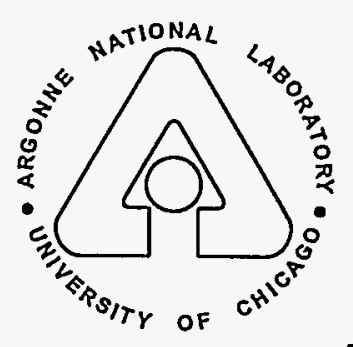

\section{ARGONNE NATIONAL LABORATORY, ARGONNE, ILLINOIS}

Operated by The University of Chicago

for the United States Department of Energy

under Contract No. W-31-109-Eng-38.

\section{MASTER}




\section{DISCLAIMER}

Portions of this document may be illegible in electronic image products. Images are produced from the best available original document. 
Table of Contents

Page

Abstract.................................................................... 1

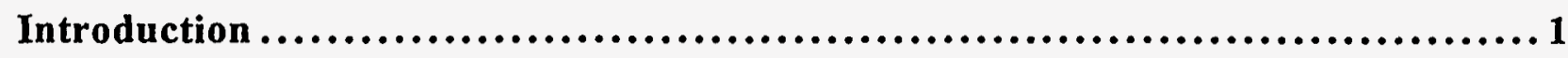

Fuel Assembly Model.....................................................2

Calculational Model........................................................ 3

Dose Rate Sensitivities...................................................4 4

Dose Rate Results......................................................6 6

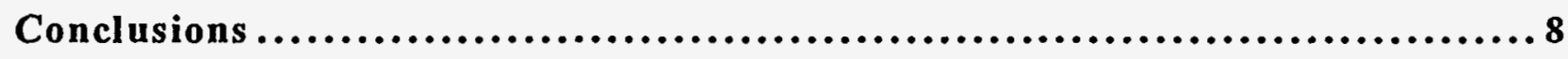

References................................................................9

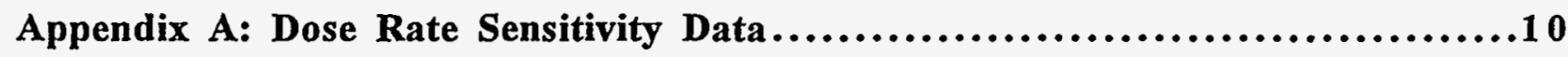

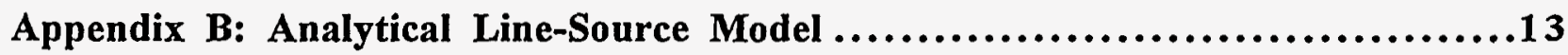




\title{
PHOTON DOSE RATES FROM SPENT FUEL ASSEMBLIES WITH RELATION TO SELF-PROTECTION
}

R. B. Pond and J. E. Matos

Argonne National Laboratory

Argonne, IL USA

\begin{abstract}
Photon dose rates as a function of fission product decay times have been calculated for spent fuel assemblies typical of MTR-type research and test reactors. Based upon these dose rates, the length of time that a spent fuel assembly will be self-protecting (dose rate greater than $100 \mathrm{rem} / \mathrm{h}$ at $1 \mathrm{~m}$ in air) can be estimated knowing the mass of fuel burned, the fraction of fuel burned, and the fuel assembly specific power density.

The calculated dose rates cover 20 years of fission product decay, spent fuel with up to $80 \%{ }^{235} \mathrm{U}$ burnup and assembly power densities ranging from 0.089 to $2.857 \mathrm{MW} / \mathrm{kg}^{235} \mathrm{U}$. Most of the results are unshielded dose rates at $1 \mathrm{~m}$ in air with some shielded dose rates at $40 \mathrm{~cm}$ in water. Dose rate sensitivity estimates have been evaluated for a variety of MTR fuel assembly designs and for uncertainties in both the physical and analytical models of the fuel assemblies.

The Monte Carlo dose rates reported in this paper are a revision of the dose rates reported in Ref. 1. These dose rates are the result of a revised energy group structure used for the MCNP calculations, and the fluence-to-dose conversion factors for the new group structure. The photon dose rates in air (water) are a factor $0.85(0.98)$ of the old photon dose rates. In addition, this paper presents an analytical method for estimating the photon dose rate of spent fuel, assuming a line-source model of the fission products in a fuel assembly.
\end{abstract}

\section{INTRODUCTION}

The photon dose rate from spent nuclear fuel is a factor, which in combination with the material form and quantity, determines the physical protection requirements ${ }^{[2]}$ for the spent fuel material. In this paper, the photon dose rate from spent fuel assemblies is calculated for the purpose of estimating the radiation level. The dose rate data are evaluated as functions of specific power density and burnup in the fuel assembly, and as a function of fission product decay time in the spent fuel. 
A fuel assembly is considered to be self-protecting when the dose rate is greater than $100 \mathrm{rem} / \mathrm{h}$ at a distance of $1 \mathrm{~m}$ in air. It is important to know if spent nuclear fuel is self-protecting or when self-protection is lost since significant and costly additional physical protection requirements could be necessary.

Because of the high-radiation fields, it is not always convenient to measure fuel assembly dose rates in an unshielded configuration. As an aid to assess spent fuel radiation levels, dose rates in air have been calculated to cover a broad range of MTR-type fuel assembly designs and burnup histories. Some dose rate calculations also have been made in a shielded configuration. These data could be useful in correlating dose rates in water to corresponding dose rates in air.

\section{FUEL ASSEMBLY MODEL}

A functional model of an MTR-type fuel assembly and the locations where dose rates were calculated is shown in Fig. 1. The fuel assembly has aluminum-clad fuel plates and aluminum side plates. The locations are typical of where dose rate measurements could be made relative to the fuel assembly. In the criterion for radiation protection, the location is unspecified other than at 1 m. The dose rate in general will be a function of the fuel assembly orientation.
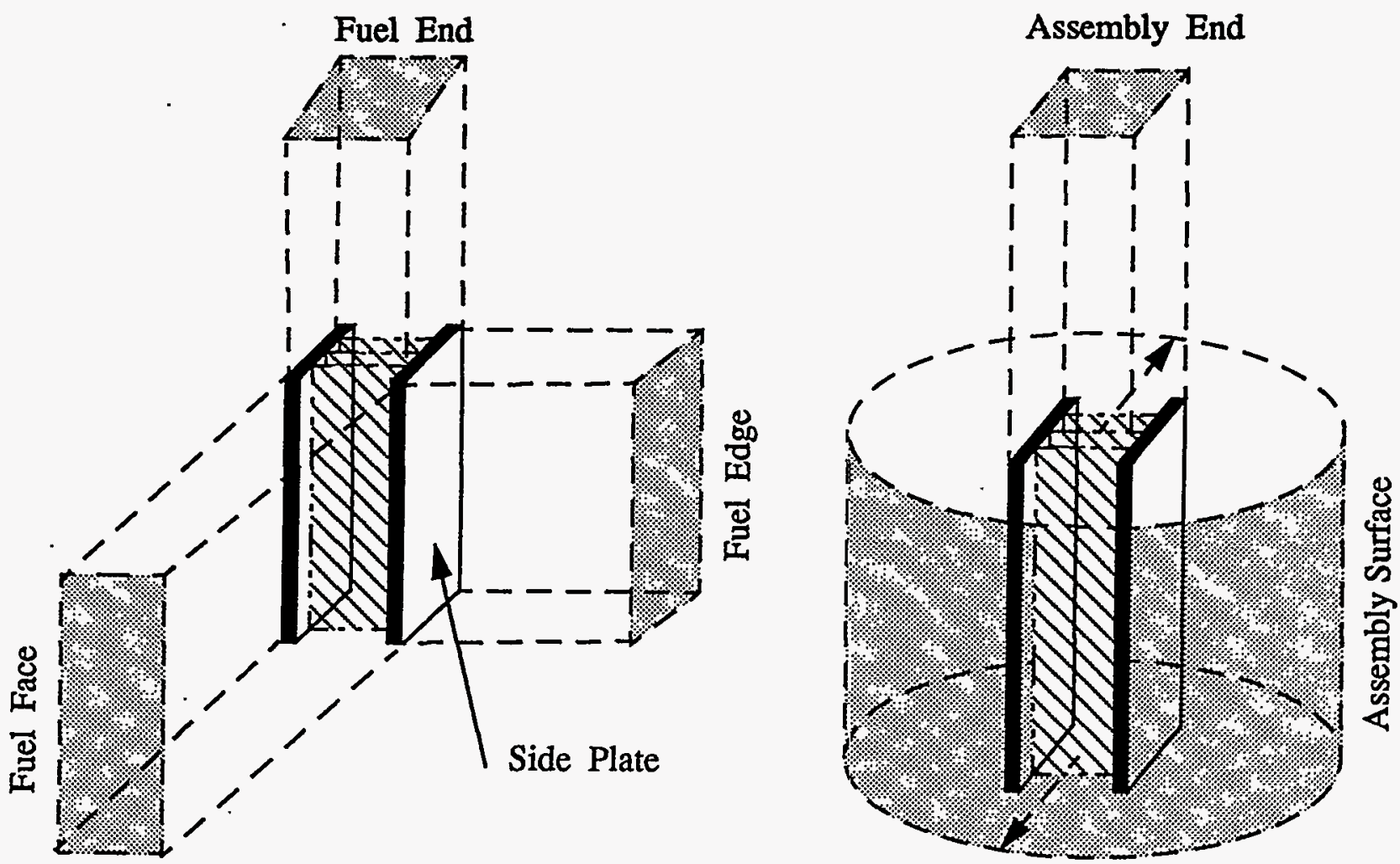

Figure 1. Model of Dose Rate Locations Relative to a Fuel Assembly 
The orientation of the fuel assembly in Fig. 1 represent locations towards the fuel-plate face, the fuel-plate edge, and the assembly end - each $1 \mathrm{~m}$ from the side plates of the fuel assembly. The cylindrical surface is located $1 \mathrm{~m}$ from the axial center line and represents an average dose rate around the fuel assembly. In all cases the dose rates were averaged over the indicated surface areas as defined by the fuel assembly dimensions.

Three MTR fuel assemblies with 16-, 19- and 23-fuel plates were modeled (Fig. 2). The assembly with 16 fuel plates has two additional outside aluminum plates. These three models represent most standard and control, plate-type fuel assemblies. In all cases the fuel assembly was modeled as $60-\mathrm{cm}$ long without end pieces.

\section{CALCULATIONAL MODEL}

The fission product photon source was calculated using $t h e$ is o tope generation and depletion code, ORIGEN ${ }^{[3]}$. The source was calculated for a ${ }^{235} \mathrm{U}$ mass with up to

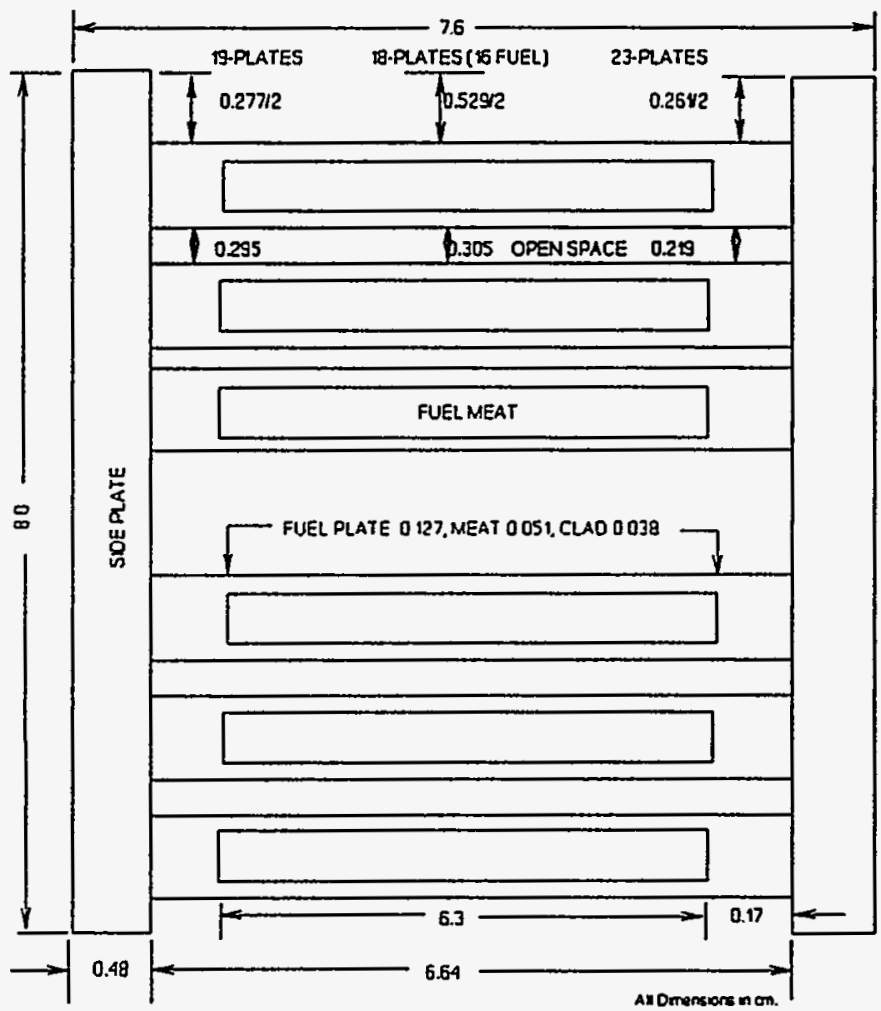

Figure 2. Cross Section of 18-, 19- and 23-Plate Fuel Assemblies

$80 \%$ burnup and for six power densities

from 0.089 to $2.857 \mathrm{MW} / \mathrm{kg}^{235} \mathrm{U}$. Burnup in these calculations is equal to the product of the fuel assembly specific power density and the exposure time in days, times the constant $1.25 \mathrm{e}^{-3} \mathrm{~kg}^{235} \mathrm{U}$ burned per MWd. At each burnup level, the fission product photon source was calculated in yearly increments through 20 years of fission product decay.

These photon source data as functions of ${ }^{235} \mathrm{U}$ burnup, assembly specific power density, and fission product decay time were then introduced into an $\mathrm{MCNP}^{[4]}$ Monte carlo model to calculate the photon flux in select regions around the fuel assembly. The photon source in all cases was uniformly distributed in the fuel meat of all fuel plates in a fuel assembly. The fuel, clad, side plates, gaps, etc. were all modeled so as to fully account for photon transport in the 
fuel assembly.

Based upon the calculated photon flux per unit photon source, the dose rates in rem/h were then calculated using the American National standard fluence-to-dose factors given in Ref. 5.

\section{DOSE RATE SENSITIVITIES}

MTR Fuel Assembly Design Variation

GAMMA DOSE RATE vS DECAY TIME as functions of $\mathrm{U}-235$ burnup, $60 \%$ and assembly power density, $1.43 \mathrm{MW} / \mathrm{kgU}-235$

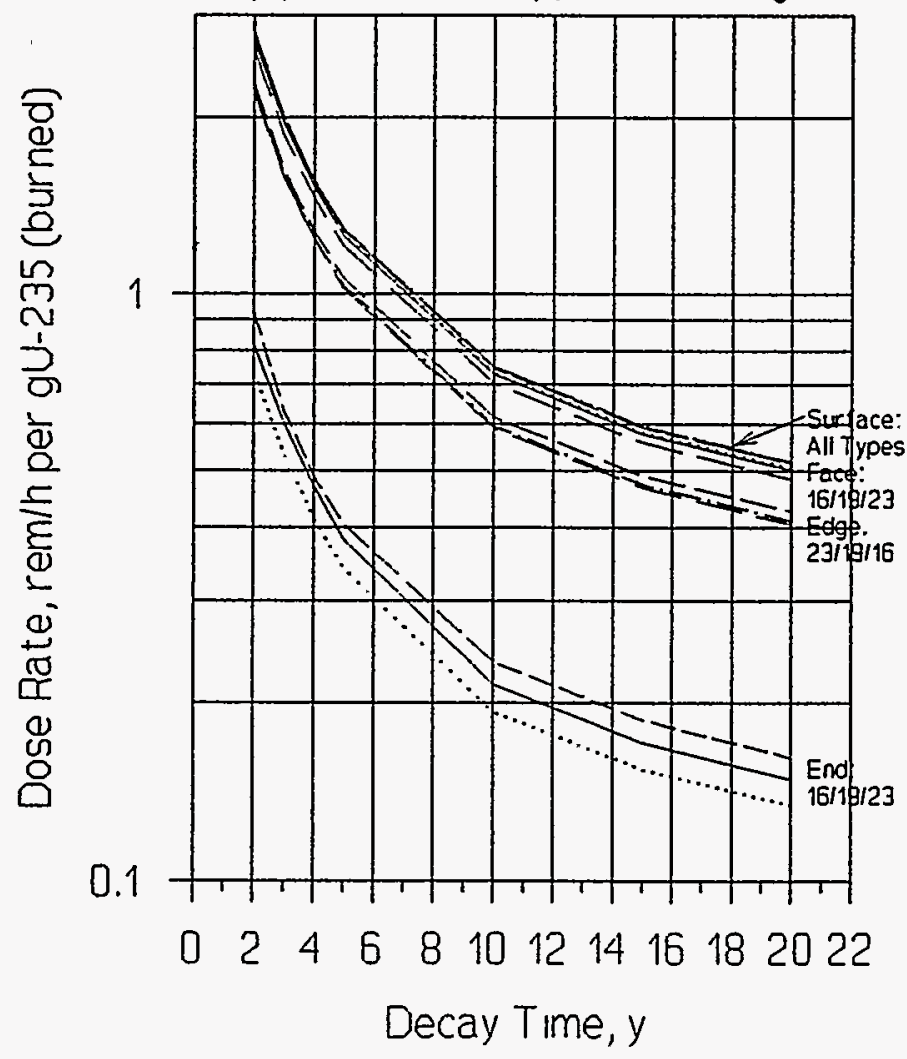

Figure 3. Surface-, Face-, Edge- and End-Location Dose Rates for Three Fuel Assembly Types
Shown in Fig. 3 are dose rates per $\mathrm{g}^{235} \mathrm{U}$ burned for the three MTR fuel assembly designs shown in Fig. 2 and for the four "1meter" regions represented in Fig. 1. Figure 3 shows the variation between the dose rates at $1 \mathrm{~m}$ from the face, edge and end of an assembly. It also shows the dose rate variation as a function of the number of fuel plates in an assembly.

Figure 3 also shows that as a function of fission product decay time, the radial surface area dose rate is, within statistics, the same for all fuel assembly designs. since the same total photon source is assumed in each fuel assembly design, the average dose rate around an assembly is approximately the

same. The insensitivity of the dose rate to the fuel assembly design is the basis for presenting all calculated dose rate data as assembly surface area dose rates. 
Constant Factors Relating Dose Rate And Photon Source

To a good approximation the calculated surface area dose rate correlates by a constant to the calculated fission product photon source. This simple correlation exists because the major contribution to both the dose rate and the photon source comes from the fission product ${ }^{137 \mathrm{~m}} \mathrm{Ba}$ with minor contributions from its parent ${ }^{137} \mathrm{Cs}$, and from ${ }^{90} \mathrm{Y}$ and its parent ${ }^{90} \mathrm{Sr}$. The photon source from these fission product chains includes bremsstrahlung radiation for beta decay in uranium.

Table 1. Ratio of Photon Dose Rate (rem/h) to Photon Source Rate (ph/s)

\begin{tabular}{|c|c|c|}
\hline \multirow{2}{*}{$\begin{array}{l}\text { Assembly } \\
\text { Power } \\
\text { Density } \\
\mathrm{MW} / \mathrm{kg}^{235} \mathrm{U}\end{array}$} & \multicolumn{2}{|c|}{ Average Ratio at $1 \mathrm{~m}$ in Air } \\
\hline & $\begin{array}{l}1 \text { to } 20 \% \text { Burnup } \\
2 \text { to } 4 \text { y Decay }\end{array}$ & $\begin{array}{l}20 \text { to } 80 \% \text { Burnup } \\
2 \text { to } 20 \mathrm{y} \text { Decay }\end{array}$ \\
\hline 2.857 & $6.75-12 \pm 4.9 \%$ & $7.44-12 \pm 4.4 \%$ \\
\hline 1.429 & $6.78-12 \pm 4.9 \%$ & $7.51-12 \pm 3.5 \%$ \\
\hline 0.714 & $6.81-12 \pm 5.1 \%$ & $7.51-12 \pm 3.7 \%$ \\
\hline 0.357 & $6.83-12 \pm 5.4 \%$ & $7.53-12 \pm 3.2 \%$ \\
\hline 0.179 & $6.92-12 \pm 5.2 \%$ & $7.58-12 \pm 2.5 \%$ \\
\hline 0.089 & $7.04-12 \pm 5.2 \%$ & $7.61-12 \pm 1.9 \%$ \\
\hline Average & $6.86-12 \pm 5.1 \%$ & $7.53-12 \pm 3.3 \%$ \\
\hline
\end{tabular}

average ratio in water at $1 \mathrm{~m}, 42.5 \mathrm{~cm}$ and 40 $\mathrm{cm}: 4.70-14 \pm 8.0 \%, 7.60-12 \pm 3.2 \%$ and $9.61-12$ $\pm 3.2 \%$, respectively.

shows the ratio $\circ f t h$ e calculated dose rate in rem/h per $g^{235} \mathrm{U}$ burned $t o t h e$ c a 1 c u 1 a $t$ ed fission product photon source in $\mathrm{ph} / \mathrm{s}$ per $\mathrm{g}^{235} \mathrm{U}$ burned. The ratio is tabulated as a function of the fuel assembly specific power density for two groupings of burnup and decay time. Ratios for water at a power density of 1.429 $\mathrm{MW} / \mathrm{kg}^{235} \mathrm{U}$ are given in the footnote.

The use of these dose-to-source ratios can replace the timeconsuming task of Monte Carlo dose rate calculations by simple, photon source calculations. The ratios are fairly insensitive to the fuel assembly specific power densities in Table 1. The approximate $4 \%$ uncertainty in the average ratio constant will translate into a similar uncertainty in the dose rate.

\section{Line Source Modeling of Fuel Assembly}

The dose rate calculated for a simple, $60-\mathrm{cm}$ long photon line source correlates very well to the radial surface area dose rate calculated for a photon source that is uniformly distributed in an MTR-type fuel assembly. At $1 \mathrm{~m}$ in air, the ratio of dose rates for a fuel-assembly model relative to a line-source model is approximately 0.92 . 
The smaller fuel-assembly model dose rate is due in part to the shielding of photons by the fuel assembly. Appendix B describes a method to make dose rate calculations using a line-source model.

\section{DOSE RATE RESULTS}

\section{Air-Water Dose Rate Correlation}

As an alternative to making photon dose rate measurements of spent fuel assemblies in air, a more convenient and natural medium may be a water environment. Water has the advantage that spent fuel assemblies are usually stored in water which provides reasonable shielding for safe dosimetry. Water also provides a natural attenuation for particle decay that can otherwise affect dose rate measurements made in air.

From the data in Table 1, which list the ratio of the surface dose rate to the photon source rate in both air and water, it is possible to establish the location in water where the shielded dose rate will be the same as the unshielded dose rate at $1 \mathrm{~m}$. A linear interpolation of the water ratio data at 40 and $42.5 \mathrm{~cm}$ shows that at $41.2 \mathrm{~cm}$, the shielded dose rate in water should be the same as the unshielded dose rate in air.

\section{Self-Protecting Dose Rates}

Based upon the calculated dose rates per $\mathrm{g}^{235} \mathrm{U}$ burned, the total mass of ${ }^{235} \mathrm{U}$ burned per fuel assembly that is required to achieve a dose rate of $100 \mathrm{rem} / \mathrm{h}$ can be easily determined. Figure 4 shows the mass of ${ }^{235} \mathrm{U}$ burned that is necessary for a spent fuel assembly to be self-protecting as a function of fission product decay time. These data are for four fuel assembly burnups from 20 to $80 \%$, and for six fuel assembly power densities from 0.089 to $2.857 \mathrm{MW} / \mathrm{kg}^{235} \mathrm{U}$. Interpolation of these data to other fuel assembly burnups and power densities can be easily made.

The data in Fig. 4 show either the minimum mass of ${ }^{235} \mathrm{U}$ burned per fuel assembly for a given number of self-protected years or the maximum number of years spent fuel will be self-protecting for a given mass of ${ }^{235} \mathrm{U}$ burned per fuel assembly. To use these figures, three characteristics of the fuel assembly should be known or estimated: (1) - the mass of ${ }^{235} \mathrm{U}$ burned, (2) - the percentage of ${ }^{235} \mathrm{U}$ burned, and (3) - the time-average specific power density.

For example, in a fuel assembly with $40 \%$ burnup that initially contained $280 \mathrm{~g}^{235} \mathrm{U}$, the mass of ${ }^{235} \mathrm{U}$ burned is $112 \mathrm{~g}$. If irradiated at a time-averaged power density of $0.089 \mathrm{MW} / \mathrm{kg}^{235} \mathrm{U}(0.025 \mathrm{MW})$, this fuel assembly would be self-protecting for a maximum of 4 years after discharge from the reactor. At $2.857 \mathrm{MW} / \mathrm{kg}^{235} \mathrm{U}(0.8 \mathrm{MW})$, the self-protection would increase to approximately 7 years after reactor discharge. To increase the number of self-protecting years at a given power density, the fuel assembly burnup would need to be increased. An increase in burnup to $60 \%$ (168 $\mathrm{g}^{235} \mathrm{U}$ burned) would increase the minimum number of self-protected years from about 10 

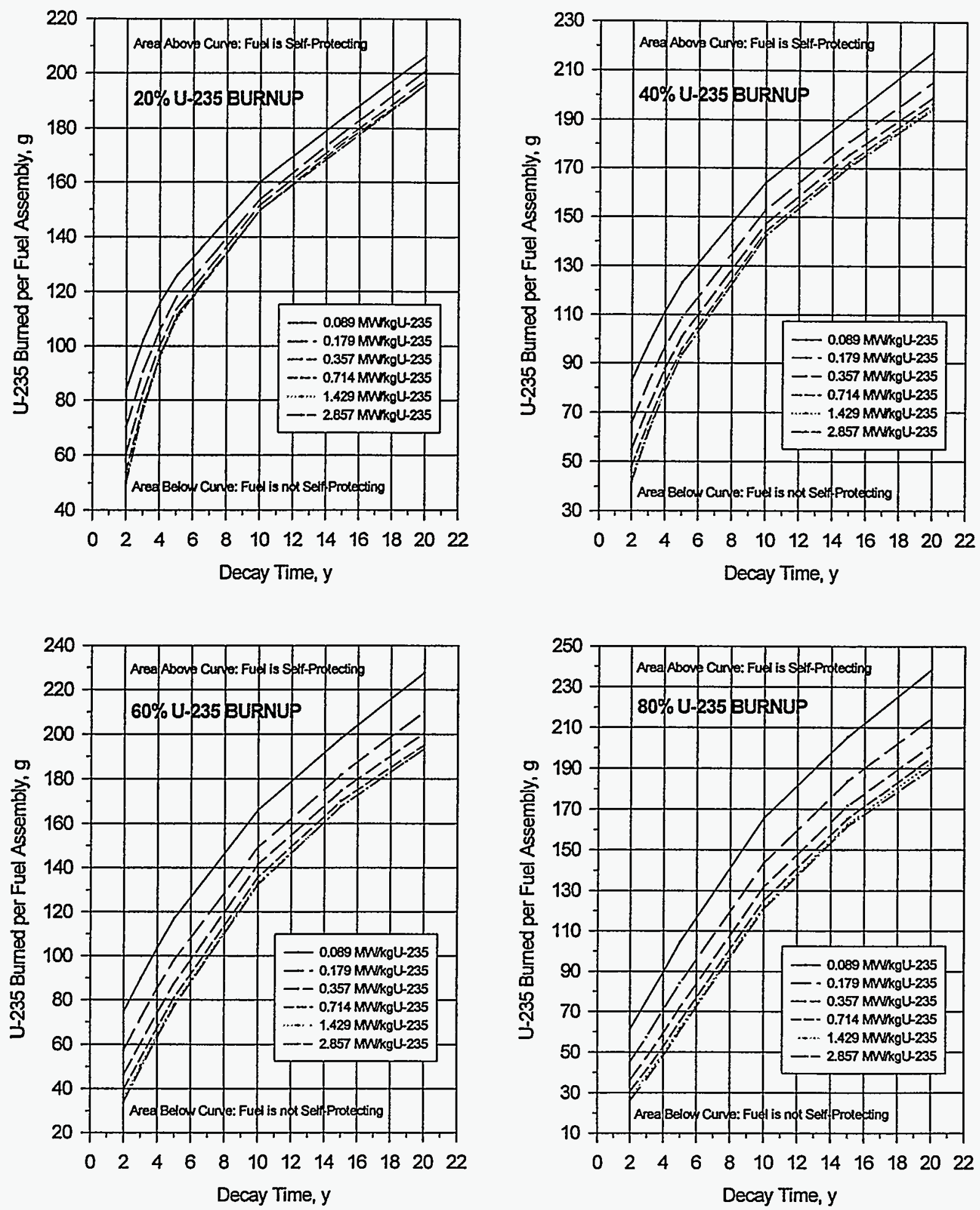

Figure 4. Mass of Burned ${ }^{235} \mathrm{U}$ per Fuel Assembly Necessary for an Unshielded $100 \mathrm{rem} / \mathrm{h}$ Dose Rate at $1 \mathrm{~m}$ for Fuel Assemblies with 20, 40, 60 and $80 \%{ }^{235} \mathrm{U}$ Burnup and Power Densities from 0.089 to $2.857 \mathrm{MW} / \mathrm{kg}^{235} \mathrm{U}$ 
to 15 years for the range of power densities from 0.089 to 2.857 $\mathrm{MW} / \mathrm{kg}^{235} \mathrm{U}$.

Throughout this paper the fuel assembly power density has been assumed to be the time-average power density that would be equivalent to the actual fuel assembly irradiation history. This assumption may not be accurate, however, for decay times less than about two years. For decay times less than two years, calculations using actual irradiation histories need to be performed since assemblies retain a "memory" of how they were irradiated. For decay time greater than two years, a fuel assembly loses virtually all memory of its irradiation history and the curves shown in Fig. 4 are independent of the fuel assembly irradiation history.

Revised Dose Rate Results

The Monte Carlo dose rates reported in this paper are a revision of the dose rates reported in Ref. 1. These dose rates are the result of a revised energy group structure used for the MCNP calculations, and the fluence-to-dose conversion factors for the new group structure. The photon dose rates in air (water) are a factor $0.85,(0.98)$ of the old photon dose rates.

\section{CONCLUSIONS}

Based upon the dose rates calculated in this paper, the length of time that a spent fuel assembly will be self-protecting (i.e., having a dose rate that is greater than $100 \mathrm{rem} / \mathrm{h}$ at $1 \mathrm{~m}$ in air) can be estimated knowing the mass of ${ }^{235} \mathrm{U}$ burned, the fraction of ${ }^{235} \mathrm{U}$ burned, and the fuel assembly specific power density. These data for a spent fuel assembly are usually known or can be reasonably estimated. The number of years that a spent fuel assembly will be self-protecting can be read directly from figures that show the $g^{235} \mathrm{U}$ burned as a function of fission product decay time.

These dose rates, however, also can be very sensitive to a number of parameters including such items as the fuel assembly orientation and the location relative to the fuel assembly. Estimates of these dose rate sensitivities have been evaluated for a variety of fuel assembly designs, and shielded (water) and unshielded (air) environments. Of much less importance are dose rate contributions from other sources such as heavy metal formation in the spent fuel, and possible material alloys and impurities in the structure of the fuel assembly. Fission products account for nearly all the dose rate in the spent fuel. These dose rate variations are discussed in Appendix A.

A simplification of dose rate calculations can be made using calculated proportionality factors that relate the spent fuel assembly dose rate to the fission product photon source. This approximation can reduce the dose rate calculation to a photon source calculation times a constant, with a small uncertainty in the result. 
Appendix $B$ describes an alternate technique to calculate photon dose rates of spent fuel that is based upon a line-source model of a fuel assembly. The technique is simple, with results that correlate very well to results based upon a detailed model of a fuel assembly and a photon source that is uniformly distributed in the fuel assembly.

\section{REFERENCES}

1. R. B. Pond and J. E. Matos, "Photon Dose Rates from Spent Fuel Assemblies with Relation to self-Protection", Proceedings of the 1995 International Meeting on Reduced Enrichment for Research and Test Reactors, Paris, France, 18-21 September 1995 (to be published).

2. "The Physical Protection of Nuclear Material," INFCIRC/225/Rev.3, International Atomic Energy Agency, Vienna, Austria (1993).

3. M. J. Bell, "ORIGEN - The ORNL Isotope Generation and Depletion Code," ORNL-4628, Oak Ridge National Laboratory, Oak Ridge, TN (1973).

4. J. F. Briesmeister, Ed., "MCNP - A General Monte Carlo NParticle Transport Code, Version 4A," LA-12625-M, Los Alamos National Laboratory, Los Alamos, NM (1993).

5. "American National Standard for Neutron and Gamma-Ray Fluenceto-Dose Factors," ANSI/ANS-6.1.1-1991, American Nuclear Society, La Grange Park, IL (1992).

6. "Nuclides and Isotopes - Chart of the Nuclides", Fourteenth Edition, General Electric Company, San Jose, CA (1989).

7. S. Glasstone and A. Sesonske, "Nuclear Reactor Engineering", Van Nostrand Reinhold Company, New York, NY (1967).

8. "Handbook of Mathematical Functions", National Bureau of Standards Applied Mathematics Series 55, United states Department of Commerce, Washington, DC (1972). 


\section{APPENDIX A}

\section{DOSE RATE SENSITIVITY DATA}

This appendix contains dose rate sensitivity data for various parameters and assumptions inherent in the fuel assembly models. These data also may be used to adjust calculated surface dose rates to compare with measured dose rates that are functions of a fuel assembly design and the fuel assembly orientation.

\section{Face-, Edge- And End-Location Dose Rate Ratios}

Table AI shows the face-, edge- and end-location dose rate ratios relative to the surface area dose rate for three fuel assembly designs. These data may be used to estimate the unshielded, $1-\mathrm{m}$ dose rates at these locations based upon the calculated surface area dose rate.

Table A1. Face-, Edge- and End-Location Dose Rate Ratios

\begin{tabular}{||c|c|c|c||}
\hline \multirow{2}{*}{$\begin{array}{c}\text { Assembly } \\
\text { Type }\end{array}$} & \multicolumn{3}{|c|}{$\begin{array}{l}\text { Dose Rate Ratio with Respect to the } \\
\text { Surface Area Dose Rate at } 1 \mathrm{~m} \text { in Air }\end{array}$} \\
\cline { 2 - 5 } & Face & Edge & End \\
\hline $16-$ Plates & $0.972 \pm 2 \%$ & $0.790 \pm 2 \%$ & $0.318 \pm 7 \%$ \\
\hline $19-$ Plates & $0.976 \pm 2 \%$ & $0.793 \pm 2 \%$ & $0.292 \pm 7 \%$ \\
\hline 23-Plates & $0.940 \pm 2 \%$ & $0.824 \pm 2 \%$ & $0.263 \pm 7 \%$ \\
\hline
\end{tabular}

a For all fuel assembly types at $40 \mathrm{~cm}$ in water, the face-, edgeand end-location dose rate ratios with respect to the surface area dose rate are $0.693 \pm 2 \%, 0.686 \pm 2 \%$ and $0.255 \pm 7 \%$, respectively.

Radial Dose Rate Variation

The variation of the surface area dose rate as a function of the distance from the center of the fuel assembly is shown in Table A2. These radial dose rate gradients were calculated for both unshielded and shielded fuel assembly configurations.
Table A2. Radial Dose Rate Gradient

\begin{tabular}{||l|r|}
\hline Medium & $\begin{array}{c}\text { Percent Change per cm } \\
\text { Relative to the } \\
\text { Surface Area Dose Rate }\end{array}$ \\
\hline Air $(1 \mathrm{~m})$ & $-1.9 \pm 1.0 \%$ \\
\hline Water $(40 \mathrm{~cm})$ & $-9.8 \pm 0.5 \%$ \\
\hline
\end{tabular}

"Applicable over a radial distance of \pm 5 $\mathrm{cm}$ relative to a radius of $1 \mathrm{~m}$ in air and $40 \mathrm{~cm}$ in water. 
Axial Dose Rate Variation

Table A3 shows the axial dose rate relative to the average surface dose rate, over five axial sections of the 60-cm active length of a fuel assembly. These results show that the axial dose rate distribution at $1-\mathrm{m}$ radius is fairly flat with only about $\pm 2 \%$ variation. At $40-\mathrm{cm}$ radius in water, the central section ( -5 to +5 $\mathrm{cm})$ dose rate is about $16 \%$ larger than the average dose rate, with similarly large $(+10 \%$ and $-12 \%)$ differences in the two other axial sections.

Table A3. Axial Dose Rate Distribution

\begin{tabular}{||l|r|r|r||}
\hline \multirow{2}{*}{ Medium } & \multicolumn{4}{|c|}{$\begin{array}{c}\text { Percent Difference Relative } \\
\text { to the Surface Area Dose Rate }\end{array}$} \\
\cline { 2 - 5 } & -5 to $+5 \mathrm{~cm}$ & $\begin{array}{r}+5 \text { to }+15 \mathrm{~cm} \\
-5 \text { to }-15 \mathrm{~cm}\end{array}$ & $\begin{array}{l}+15 \text { to }+30 \mathrm{~cm} \\
-15 \text { to }-30 \mathrm{~cm}\end{array}$ \\
\hline Air $(1 \mathrm{~m})$ & $2.9 \pm 0.3$ & $1.8 \pm 0.2$ & $-2.2 \pm 0.2$ \\
\hline Water $(40 \mathrm{~cm})$ & $15.8 \pm 0.3$ & $10.2 \pm 0.3$ & $-12.0 \pm 0.2$ \\
\hline
\end{tabular}

Aluminum Alloy Materials And Impurities

A number of aluminum alloys containing different alloying materials and impurities are used to manufacture MTR-type fuel assemblies. Table A4 lists a representative sample of the material alloys and impurities commonly found in Al-6061 which is used here as an example. A typical fuel assembly contains about $3 \mathrm{~kg}$ of aluminum alloys in the side plates and cladding of the active portion of the fuel plates.

Table A4. Al-6061 Material Alloys and Impurities

\begin{tabular}{||lr|lr|lr|ll||}
\hline \hline Mat' 1 & ppm & Mat' l & ppm & Mat' 1 & ppm & Mat'1 & ppm \\
\hline Li & 10 & Ti & 300 & Co & 10 & Ga & 100 \\
\hline B & 10 & Cr & 1700 & Ni & 500 & Zr & 10 \\
\hline Mg & 8800 & Mn & 300 & Cu & 2600 & Cd & 10 \\
\hline Si & 7000 & Fe & 2400 & Zn & 500 & Sn & 500 \\
\hline
\end{tabular}

Results of dose rate calculations for Al-6061 shows that the major dose rate contributor is ${ }^{60} \mathrm{Co}$ with minor contributions from ${ }^{65} \mathrm{Zn}$ and ${ }^{54} \mathrm{Mn}$. The latter materials have half-lives of less than a year which leaves ${ }^{60} \mathrm{Co}$, with a $5.3 \mathrm{y}$ half-life, the only major component. Relative to the dose rate of fission products per gram of ${ }^{235} \mathrm{U}$ burned, the dose rate of cobalt per kilogram of Al-6061 is an order of magnitude smaller. 
Heavy Metals

Dose rate calculations were made for the heavy metals generated in the burning of $93 \%$ enriched uranium fuel. These data showed that the contribution of heavy metals to the dose rate per gram of ${ }^{235} U$ burned was five orders of magnitude smaller than the contribution of fission products. Similar dose rate calculations for LEU fuel showed that the heavy metal contribution was larger, but still three orders of magnitude smaller than the contribution of fission products. 


\section{APPENDIX B}

\section{ANALYTICAL LINE-SOURCE MODEL}

This appendix contains the description of a technique that estimates the photon dose rate of spent fuel, assuming a linesource model of the fission products in a fuel assembly. A comparison of line-source model dose rates to corresponding fuelassembly model dose rates are also made.

\section{Introduction}

Photon dose rate estimates are based upon generating a photon source for the fission products in spent reactor fuel, calculating the photon flux at a point of observation, and correlating the photon flux to a radiation dose. Various measures of the effective radiation dose may be used depending upon recommended biological exposure criteria. For purposes of this work, the most conservative fluence-to-dose estimates from Ref. 5 have been chosen. The purpose of this appendix is to present a simple technique to generate the photon source and to calculate the photon flux. All dose rates are estimated at $1 \mathrm{~m}$ in air from the photon source.

The technique generates the photon source of the primary fission products in spent fuel and calculates the photon flux using a sievert integral. This technique compares to the photon source generated by ORIGEN and the photon flux calculated using MCNP. BY modeling the actual, distributed fission product source in the fuel assembly by a line source, the photon flux can be calculated using a much simpler technique. A further simplification of generating only the primary fission products is justified since the majority of all fission products, in the time interval between two and 20 years of fission product decay, are accounted for by just 10 fission products.

Calculations show that the ratio of dose rates of the fuelassembly model/Monte Carlo technique relative to the line-source model/sievert integral technique is approximately 0.92 . This difference in dose rate is largely the effect of photon shielding by the fuel assembly. Analyses otherwise show good agreement of photon dose rates calculated for a line-source model using either sievert integral or Monte Carlo techniques.

A Fortran computer program (PHDOSE) is attached to this appendix which may be used to calculate the photon dose rate of spent fuel. The program calculates the photon source for the 10 primary fission products, the sievert-integral photon flux, and the photon dose rate, given flux-to-dose conversion factors for three photon energy groups. Input to the program requires the fuel assembly irradiation time, specific power density and power, and the fission product decay time in the spent fuel. 


\section{Primary Fission Products}

The equations for the formation of six fission product pairs ${ }^{90} \mathrm{Sr}-{ }^{90} \mathrm{Y},{ }^{95} \mathrm{Zr}-{ }^{95} \mathrm{Nb},{ }^{106} \mathrm{Ru}-{ }^{106} \mathrm{Rh},{ }^{133} \mathrm{Cs}-{ }^{134} \mathrm{Cs},{ }^{137} \mathrm{Cs}-{ }^{137 m} \mathrm{Ba}$, and ${ }^{144} \mathrm{Ce}-$ ${ }^{144} \mathrm{Pr}$, together with the equation for the formation of ${ }^{60} \mathrm{Co}$ are given below. The equation for ${ }^{60} \mathrm{Co}$, which is not a fission product, is given since it is a possible photon source in spent fuel arising from the activation of ${ }^{59} \mathrm{Co}$. If cobalt is present in a fuel assembly, it is usually small and with its fairly short half-life, will not compete with the primary fission products. The two fission product pairs ${ }^{90} \mathrm{Sr}-{ }^{90} \mathrm{Y}$ and ${ }^{137} \mathrm{Cs}-{ }^{37 \mathrm{~m}} \mathrm{Ba}$ are the primary dose rate contributors after a few years of fission product decay. of the 12 fission products, only 10 actually contribute to the dose rate. While not photon emitters, equations for ${ }^{106} \mathrm{Ru}$ and ${ }^{133} \mathrm{Cs}$ are included since they are the precursors of ${ }^{106} \mathrm{Rh}$ and ${ }^{134} \mathrm{Cs}$; direct fission product production of ${ }^{106} \mathrm{Rh}$ or ${ }^{134} \mathrm{Cs}$ is small.

Table B1 lists the physics data that have been used in the equations to estimate the number of atoms of each fission product and cobalt. The number of atoms at any time ( $t$ ) due to radioactive decay of a material that can neglect radioactive precursors, is given by:

$$
{ }^{m} N={ }^{m} N_{0} e^{-\lambda_{m} t}
$$

where for material $\mathrm{m}, \lambda_{\mathrm{m}}$ is the decay constant and ${ }^{\mathrm{m}} \mathrm{N}_{0}$ is the number of atoms initially present. When a radioactive parent is present, the number of atoms of a radioactive daughter is given by:

$$
{ }^{d} N=\frac{\lambda_{p}{ }^{p} N_{0}}{\left(\lambda_{d}-\lambda_{p}\right)}\left(e^{-\lambda_{p} t}-e^{-\lambda_{d} t}\right)+d^{d} N_{0} e^{-\lambda_{d} t} \approx \frac{\lambda_{p}{ }^{p} N}{\lambda_{d}} \text { when } \lambda_{d}>\lambda_{p} \text { and } e^{-\lambda_{d} t} \approx 0
$$

where the sub- and super-scripts refer to the daughter (d) and parent (p) materials. The number of atoms initially present is given by equations that depend upon the material, the specific power density, and the irradiation time.

Production of ${ }^{90} \mathrm{Sr},{ }^{95} \mathrm{Zr},{ }^{106} \mathrm{Ru},{ }^{133} \mathrm{Cs},{ }^{137} \mathrm{Cs}$ And ${ }^{144} \mathrm{Ce}$

The number of atoms $\left({ }^{\mathrm{m}} \mathrm{N}_{0}\right)$ of ${ }^{90} \mathrm{Sr},{ }^{95} \mathrm{Zr},{ }^{106} \mathrm{Ru},{ }^{133} \mathrm{Cs},{ }^{137} \mathrm{Cs}$ or ${ }^{144} \mathrm{Ce}$ is given by the following equation where during the irradiation time $\left(t_{i}\right)$, the net production rate is proportional to the fission product yield $\left(Y_{m}\right)$ and power, minus the fission product decay $\left(\lambda_{m}\right)$ and capture $\left(\sigma_{m}\right)$ rates. The average neutron flux in the equation is proportional to the time-average specific power density during the irradiation time. Units for the power and power density are indicated in square brackets. 


$$
m_{N_{0}}=\frac{R_{m}}{K_{m}}\left(1-e^{-K_{m} t_{1}}\right) \text { with } K_{m}=(\lambda+\sigma \bar{\phi})_{m}
$$

where $R_{m}=3.121$ e16 fiss $/ \mathrm{s} \cdot Y_{m}$ atoms $/$ fiss $\cdot P$ [MW] and $\bar{\phi}=2.952 e 13 \mathrm{n} / \mathrm{cm}^{2}-s \cdot \bar{P}_{d}\left[M W / \mathrm{kg}^{235} \mathrm{U}\right]$

The fission product formation rate $\left(R_{m}\right)$ is based upon a value of $200 \mathrm{MeV}$ per fission and the neutron flux, which is inversely proportional to $\Sigma_{f \prime}$ assumes a value of the ${ }^{235} U$ fission cross section, $\sigma_{\mathrm{f}}=412.6 \mathrm{~b}$. The average flux is calculated using the average mass of ${ }^{235} \mathrm{U}$ in determining the specific power density.

Production of ${ }^{90} \mathrm{Y},{ }^{95} \mathrm{Nb},{ }^{106} \mathrm{Rh},{ }^{137 \mathrm{~m}} \mathrm{Ba}$ And ${ }^{144} \mathrm{Pr}$

The number of atoms $\left({ }^{\mathrm{d}} \mathrm{N}_{0}\right)$ of ${ }^{90} \mathrm{Y},{ }^{95} \mathrm{Nb},{ }^{106} \mathrm{Rh},{ }^{137 \mathrm{~m}} \mathrm{Ba}$ or ${ }^{144} \mathrm{Pr}$, which are the fission product daughters of ${ }^{90} \mathrm{Sr},{ }^{95} \mathrm{Zr},{ }^{106} \mathrm{Ru},{ }^{137} \mathrm{Cs}$ and ${ }^{144} \mathrm{Ce}$, are related to the number of atoms $\left({ }^{P} \mathrm{~N}_{0}\right)$ of the parents by their decay constants. Because the half-lives of all the daughters (except ${ }^{95} \mathrm{Nb}$ ) are very short compared to the parents, the decay rates are in equilibrium. The number of atoms is given by:

$$
\begin{gathered}
{ }^{d} N_{0}=\frac{\lambda_{p} R_{p}}{K_{p} K_{d}}\left(1-e^{-K_{d} t_{1}}\right)-\frac{\lambda_{p} R_{p}}{K_{p}\left(K_{d}-K_{p}\right)}\left(e^{-K_{p} t_{1}}-e^{-K_{d} t_{1}}\right) \text { with } K_{m}=(\lambda+\sigma \bar{\phi})_{m} \\
{ }^{d} N_{0} \approx \frac{\lambda_{p}{ }^{p} N_{0}}{K_{d}} \approx \frac{\lambda_{p}{ }^{p} N_{0}}{\lambda_{d}} \text { when } K_{d} \approx \lambda_{d}>K_{p} \text { and } e^{-K_{d} t_{1}} \approx 0
\end{gathered}
$$

\section{production of ${ }^{134} \mathrm{Cs}$}

The number of atoms of ${ }^{134} \mathrm{Cs}$ is given by the following equation which is based upon the number of ${ }^{133} \mathrm{Cs}$ atoms and a ${ }^{133} \mathrm{Cs}(n, \gamma){ }^{134} \mathrm{Cs}$ reaction. The direct fission product production of ${ }^{134} \mathrm{Cs}$ is small and is neglected. The ${ }^{133} \mathrm{Cs}$ production rate $\mathrm{R}_{133}$ is given above.

$$
{ }^{134} C S_{0}=\frac{R_{133}}{K_{134}}\left(1-e^{-K_{134} t_{i}}\right)-\frac{R_{133}}{\left(K_{134}-K_{133}\right)}\left(e^{-K_{133} t_{1}-e^{-K_{134} t_{i}}}\right) \text { with } K_{m}=(\lambda+\sigma \bar{\phi})_{m}
$$

\section{Production of ${ }^{60} \mathrm{Co}$}

The number of atoms of ${ }^{60} \mathrm{Co}$ is given by the following equation which is based upon the number of ${ }^{59} \mathrm{Co}$ atoms and a ${ }^{59} \mathrm{Co}(n, \gamma){ }^{60} \mathrm{Co}$ reaction. In the equation ${ }^{59} \mathrm{Co}$ is specified as a fractional part of the fuel assembly (FA) mass. 


$$
{ }^{60} \mathrm{CO}_{0}=\frac{R_{59}}{K_{60}}\left(1-e^{-K_{60} t_{1}}\right) \text { with } K_{60}=(\lambda+\sigma \bar{\phi})_{60}
$$

where $R_{59}=1.197$ e10 atoms/s per $\mathrm{kg}$ FA mass per ppm ${ }^{59} \mathrm{Co} \cdot \bar{P}_{d}\left[\mathrm{MW} / \mathrm{kg}^{235} \mathrm{U}\right]$

The cobalt reaction rate $R_{59}$ is based upon a ${ }^{59} \mathrm{Co}$ capture cross section, $\sigma_{c}=39.67 \mathrm{~b}$.

\section{Photon Source Rate}

For material $\mathrm{m}$, the disintegration rate $\left({ }^{\mathrm{m}} \mathrm{D}\right)$ and the photon source rate $\left({ }^{\mathrm{m}} \mathrm{S}_{\mathrm{g}}\right)$ as a function of energy, are given by:

$$
{ }^{m} D=\lambda_{m}{ }^{m} N \text { and }{ }^{m} S_{g}={ }^{m} C_{g}{ }^{m} D
$$

where ${ }^{\mathrm{m}} \mathrm{C}_{\mathrm{g}}$ is the number of photons emitted per disintegration in energy group $g$. The energy dependent photon emission constants for each material are included in Table BI. Bremsstrahlung photons from fission product beta decay in $\mathrm{UO}_{2}$ are included in the emission constants for ${ }^{90} \mathrm{Sr},{ }^{90} \mathrm{Y},{ }^{106} \mathrm{Rh},{ }^{137} \mathrm{Cs}$ and ${ }^{144} \mathrm{Pr}$.

\section{Photon Dose Rate}

If the material $\mathrm{m}$ photon source rate $\left({ }^{\mathrm{m}} \mathrm{S}_{\mathrm{g}}\right)$ is assumed to be distributed in a line source $60-\mathrm{cm}$ long, the photon flux $\left({ }^{\mathrm{m}} \phi_{\mathrm{g}}\right)$ at a perpendicular distance of $1 \mathrm{~m}$ in air at the mid-length of the line source, is given by ${ }^{[7]}$ :

$$
{ }^{m} \phi_{g}\left[p h / \mathrm{cm}^{2}-s\right]={ }^{m} S_{g}[\mathrm{ph} / s] \cdot F(\theta, \mu t) /(2 \pi \cdot 60 \mathrm{~cm} \cdot 100 \mathrm{~cm})
$$

The function $F(\theta, \mu t)$ is the secant or sievert integral ${ }^{[8]}$ which is equal to approximately 0.29 when $\theta=\operatorname{arc} \tan (30 \mathrm{~cm} / 100 \mathrm{~cm})=16.7^{\circ}$ and $\mu t=0.0$ at $1 \mathrm{~m}$ in air. (The attenuation coefficient $(\mu$ ) for air is of the order of $3.35 e-5 \mathrm{~cm}^{-1}$ and for $t=100 \mathrm{~cm}, \mu t=0.003$ ). The variation of the attenuation coefficient for air is small over the energy range between 0.3 and $1.1 \mathrm{MeV}$, and therefore, as a function of energy, the group photon flux is proportional to the photon emission $\left({ }^{m} C_{g}\right)$. With these data the photon flux is equal to $7.692 e^{-6}$ times the photon source rate $\left({ }^{\mathrm{m}} \mathrm{S}_{\mathrm{g}}\right)$.

The photon dose rate corresponding to a photon flux is given in Table B2 as a function of the photon energy. The data in the third and fourth columns of Table B2 are from Ref. 5, and the fluxto-dose conversion factors in the second column are linearinterpolated values for the photon energies in the first column. For the three photon energies of interest $(0.30,0.63$ and 1.10 $\mathrm{MeV})$, the flux-to-dose conversion factors are $5.616 \mathrm{e}-7,1.122 \mathrm{e}-6$ and $1.774 \mathrm{e}-6 \mathrm{rem} / \mathrm{h}$ per $\mathrm{ph} / \mathrm{cm}^{2}-\mathrm{s}$. 


\section{ORIGEN Vs. Program-Calculated Photon Source Rates}

Total photon source rates generated by ORIGEN and by the above equations for the 10 photon emitting fission products are tabulated in Tables $\mathrm{B} 3$ and $\mathrm{B} 4$, respectively. These source rates are given in units of $\mathrm{ph} / \mathrm{s}$ per $\mathrm{g}^{235} \mathrm{U}$ burned and as functions of burnup, specific power density, and decay time. The total photon source rate is the sum of the photon source rate at all photon energies. In case of the ORIGEN total source rate, the sum is over all energies from $27.5 \mathrm{keV}$ to $5.25 \mathrm{MeV}$ (18 groups), and for the program-calculated (PHDOSE) total source rate, the sum is over energies from 0.3 to $1.1 \mathrm{MeV}$ (3 groups).

Tables B3 and B4 show that the program-calculated source rates tend to be underestimated for short-decay times and overestimated for long-decay times. The overall agreement of the ORIGEN and the PHDOSE source rates are within a few percent.

\section{Iine-Source Model Photon Dose Rates}

Calculated dose rates with the ORIGEN and PHDOSE source rates are tabulated in Tables $\mathrm{B} 5$ and $\mathrm{B} 6$, respectively. These dose rates are based upon line-source model sievert integrals with 18-energy groups for ORIGEN distributions and with 3-energy groups for PHDOSE distributions. These line-source model dose rates, like the photon source rates, are in similar agreement.

To illustrate the relative agreement of these line-source model/sievert integral dose rates, dose rates for a fuel assembly with $40 \%{ }^{235} \mathrm{U}$ burnup and a power density of $0.089 \mathrm{MW} / \mathrm{kg}^{235} \mathrm{U}$ are plotted in Fig. B1. Figure BI also shows the Monte Carlo (18-group MCNP) line-source model dose rates calculated with the oRIGEN photon source rate distribution. The MCNP and the sievert integral dose rates are in near agreement for all decay times. The small difference in dose rate is due in part to the difference in the photon flux calculated by the Monte carlo and the sievert integral techniques. The sievert integral dose rates are slightly larger than the MCNP dose rate. This difference is consistent since the sievert integral dose rate is for a ring at the mid-point of the $60-\mathrm{cm}$ long line source while the MCNP dose rate is an average over the fuel assembly surface area.

The diamond-shaped data points shown in Fig. B1 at 5 and 10 years, are MCNP calculated dose rates in vacuum, at $1 \mathrm{~m}$ from the line source. Within statistics $(1 \sigma)$ the Monte carlo dose rates in air or in vacuum are the same. Based upon this result, air acts like a void with no photon attenuation or buildup.

\section{Cobalt Photon Dose Rates}

Dose rates for ${ }^{60} \mathrm{Co}$ calculated with the PHDOSE program are tabulated in Table B7. The dose rates are calculated for the same irradiation conditions as fuel, and therefore, can be compared on a relative basis to the fission product dose rates tabulated in 
Table $\mathrm{B} 6$. The ${ }^{60} \mathrm{Co}$ dose rates are per kilogram of assembly mass per ppm of ${ }^{59} \mathrm{Co}$.

To illustrate the use of these data, the ${ }^{60} \mathrm{Co}$ dose rate is 0.65 $\mathrm{rem} / \mathrm{h}$ and the fission product dose rate is $112 \mathrm{rem} / \mathrm{h}$, assuming a 3 $\mathrm{kg}$ assembly mass, $10 \mathrm{ppm}{ }^{59} \mathrm{Co}$ and $100 \mathrm{~g}^{235} \mathrm{U}$ burned. These dose rates are calculated from data in Tables B6 and B7 for a fuel assembly with $40 \%{ }^{235} \mathrm{U}$ burnup, a power density of $0.089 \mathrm{MW} / \mathrm{kg}^{235} \mathrm{U}$, and for 3 years of fission product and ${ }^{60} \mathrm{Co}$ decay. In this example and for most situations, it is expected that the fission product dose rate will exceed the dose rate of ${ }^{60} \mathrm{Co}$.

\section{Fuel-Assembly Model Photon Dose Rates}

Fuel-assembly model dose rates are tabulated in Tables B8 and B9. The dose rates in Table B8 are based upon 23-group MCNP calculations reported in Ref. 1 and the dose rates in Table $B 9$ are based upon new 18-group MCNP calculations. The difference in dose rates is primarily due to the flux-to-dose conversion factors appropriate for the different energy group structures. (The group structure of Ref. 1 is no longer used and the Ref. 1 dose rates should therefore be revised.) The ratio of the new dose rates relative to the Ref. 1 dose rates is 0.85 . Figure B2 shows for example, the MCNP calculated dose rates for a fuel assembly with $40 \%{ }^{235} \mathrm{U}$ burnup and a power density of $0.089 \mathrm{MW} / \mathrm{kg}^{235} \mathrm{U}$.

For purpose of correlating fuel-assembly model dose rates with line-source model dose rates, the ratio of the MCNP-FA Model dose rates (Fig. B2) relative to the MCNP-LS Model dose rates (Fig. B1) is approximately 0.92 .

\section{Self-Protecting Fuel Assembly Masses}

Self-protecting fuel assembly masses corresponding to the revised fuel-assembly model dose rates (Table B9) are tabulated in Table B10 and shown in Figs. B3 - B6 for $20-80 \%{ }^{235} \mathrm{U}$ burnup. Table B11 are self-protecting fuel assembly masses corresponding to the line-source model dose rates (Table B6) calculated with the PHDOSE program. These latter masses have been adjusted by a factor of 0.92 in order to estimate equivalent, fuel-assembly model self-protecting masses. A comparison of these self-protection fuel assembly masses indicate that dose rate estimates using the PHDose program are in reasonable agreement with the Monte Carlo dose rate results.

\section{Summary}

Equations have been developed that will estimate the photon dose rate of specific fission products in spent (uranium) fuel. The equations are based upon the natural laws of radioactive growth and decay, and material constants (Table B1) applicable to the specific fission products. The fission products include ${ }^{90} \mathrm{Sr},{ }^{90} \mathrm{Y},{ }^{95} \mathrm{Zr},{ }^{95} \mathrm{Nb}$,

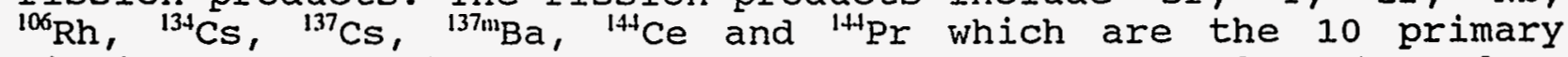
fission products in spent fuel that have short- and long-term dose rate effects. 
The dose rates are calculated at $1 \mathrm{~m}$ in air, from a $60-\mathrm{cm}$ long line source that represent the fission products in a spent fuel assembly. The photon inventory of the primary fission products is calculated as a function of the fuel assembly irradiation time, the specific fuel assembly power density, the initial ${ }^{235} \mathrm{U}$ mass, and the fission product decay time.

The line-source model photon source and dose rates, and selfprotecting fuel assembly masses are tabulated in Tables B4, B6 and B1I, respectively. These results can be compared to corresponding fuel-assembly model results that are tabulated in Tables B3, B9 and B10, respectively. The ratio of fuel-assembly model dose rates to line-source model dose rates is approximately 0.92 . 
GAMMA DOSE RATE vS DECAY TIME as functions of U-235 burnup, $40 \%$ and

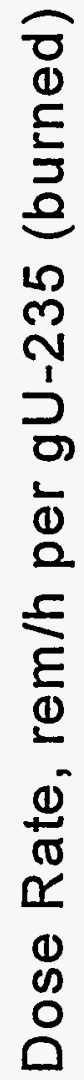
assembly power density, $0.089 \mathrm{MW} / \mathrm{kgU}-235$

0.1

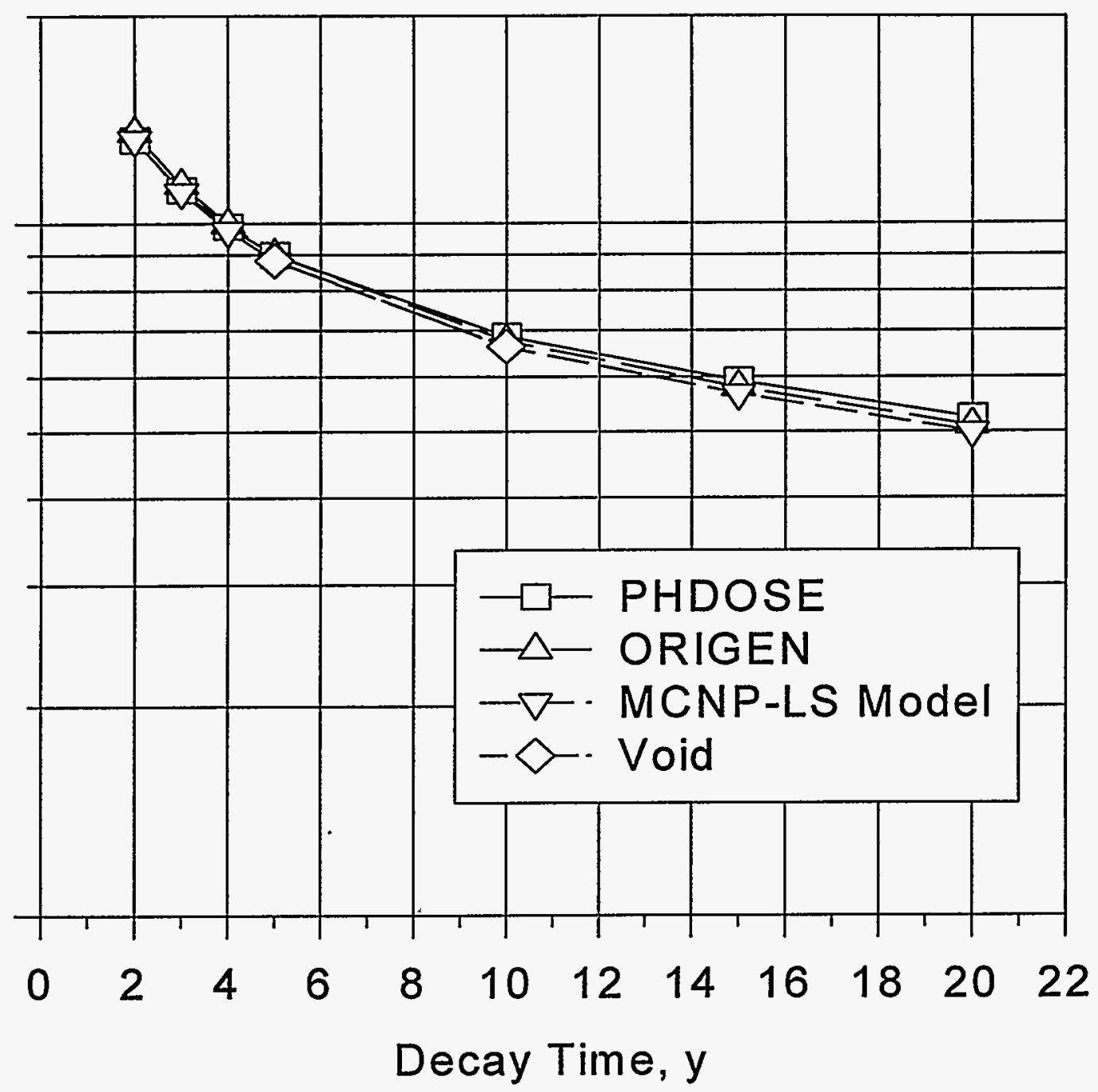

Figure B1. Line-Source Model Photon Dose Rates 
GAMMA DOSE RATE VS DECAY TIME as functions of U-235 burnup, $40 \%$ and assembly power density, $0.089 \mathrm{MW} / \mathrm{kgU}-235$

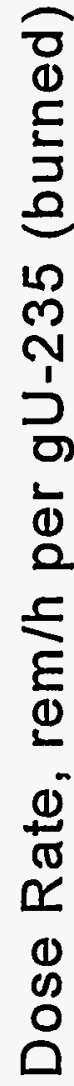

0.1

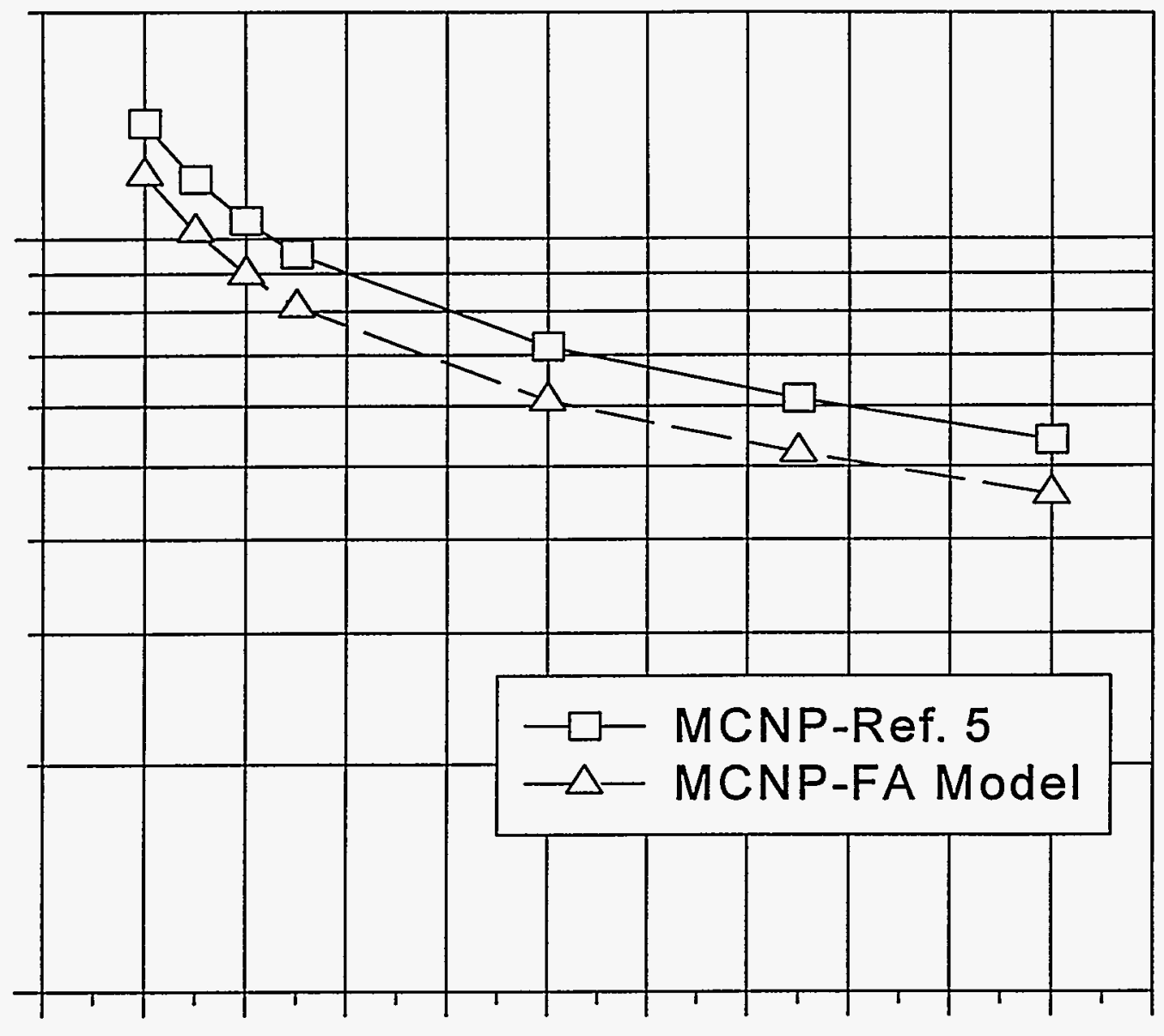

$\begin{array}{llllllllllll}0 & 2 & 4 & 6 & 8 & 10 & 12 & 14 & 16 & 18 & 20 & 22\end{array}$

Decay Time, y

Figure B2. Fuel-Assembly Model Photon Dose Rates 


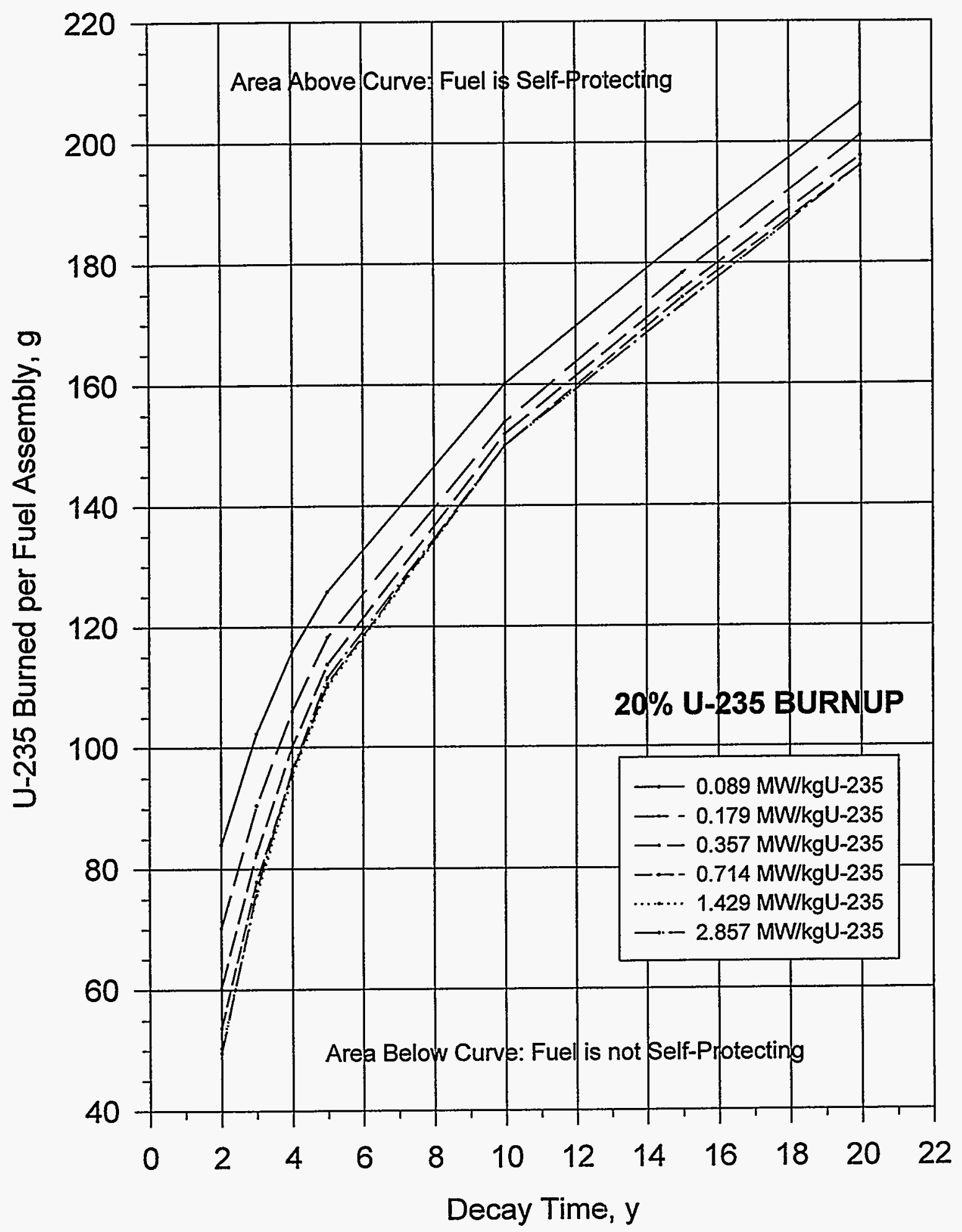

Figure B3. Mass of Burned ${ }^{235} \mathrm{U}$ per Fuel Assembly Necessary for an Unshielded $100 \mathrm{rem} / \mathrm{h}$ Dose Rate at $1 \mathrm{~m}$ for a Fuel Assembly with $20 \%{ }^{235} \mathrm{U}$ Burnup and Power Densities from 0.089 to $2.857 \mathrm{MW} / \mathrm{kg}^{235} \mathrm{U}$ 


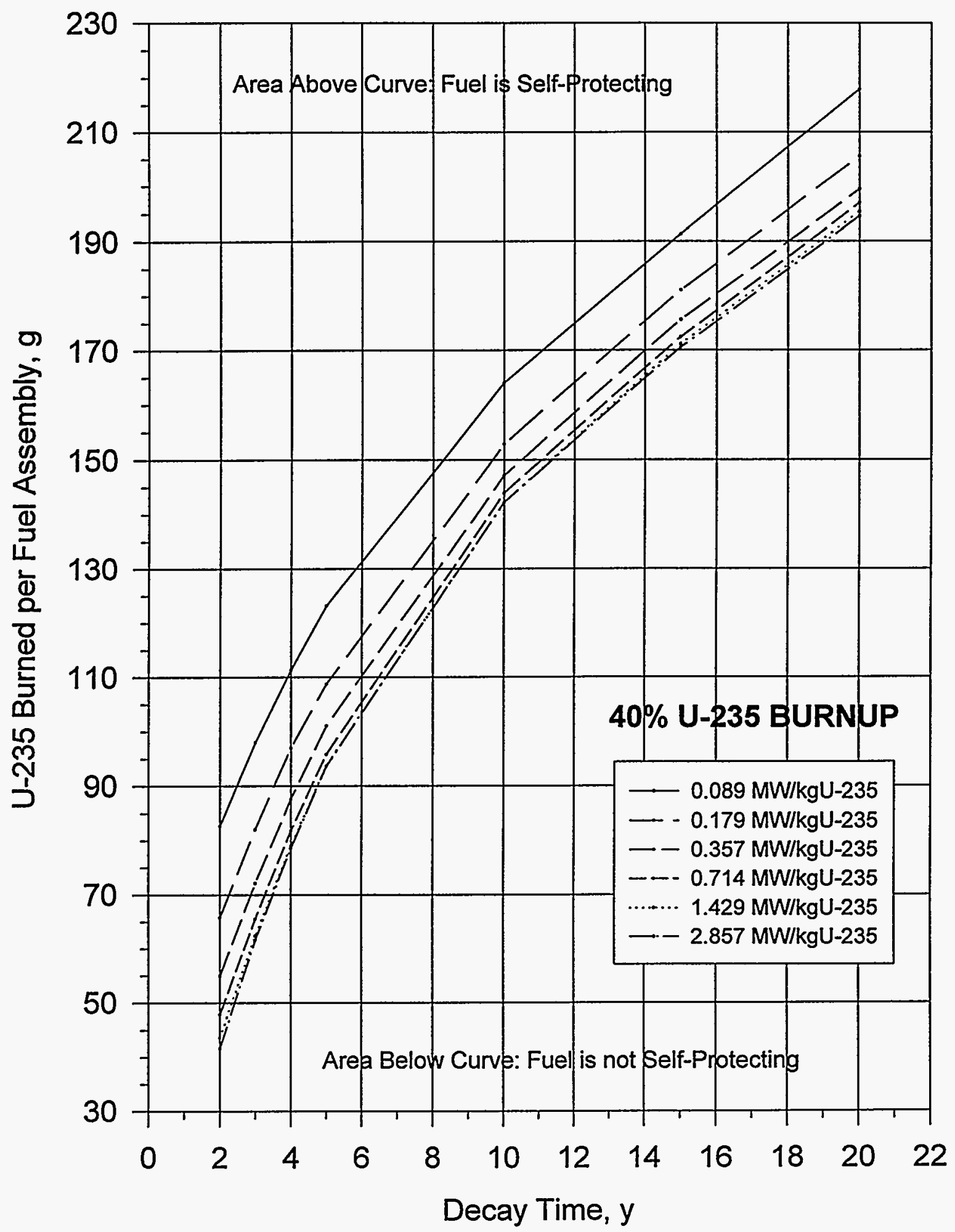

Figure B4. Mass of Burned ${ }^{235} \mathrm{U}$ per Fuel Assembly Necessary for an Unshielded $100 \mathrm{rem} / \mathrm{h}$ Dose Rate at $1 \mathrm{~m}$ for a Fuel Assembly with $40 \%{ }^{235} \mathrm{U}$ Burnup and Power Densities from 0.089 to $2.857 \mathrm{MW} / \mathrm{kg}^{235} \mathrm{U}$ 


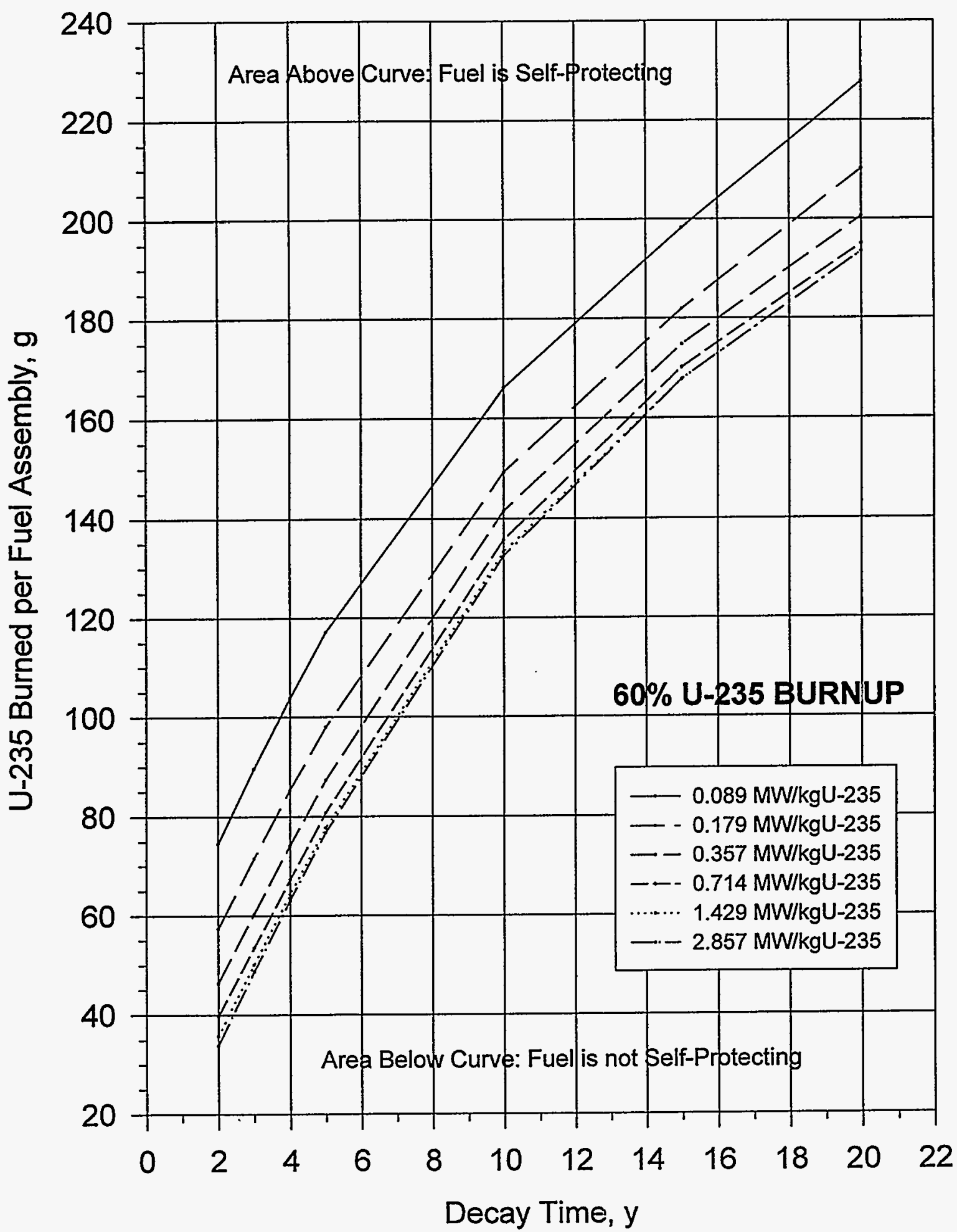

Figure B5. Mass of Burned ${ }^{235} \mathrm{U}$ per Fuel Assembly Necessary for an Unshielded $100 \mathrm{rem} / \mathrm{h}$ Dose Rate at $1 \mathrm{~m}$ for a Fuel Assembly with $60 \%{ }^{235} \mathrm{U}$ Burnup and Power Densities from 0.089 to $2.857 \mathrm{MW} / \mathrm{kg}^{235} \mathrm{U}$ 


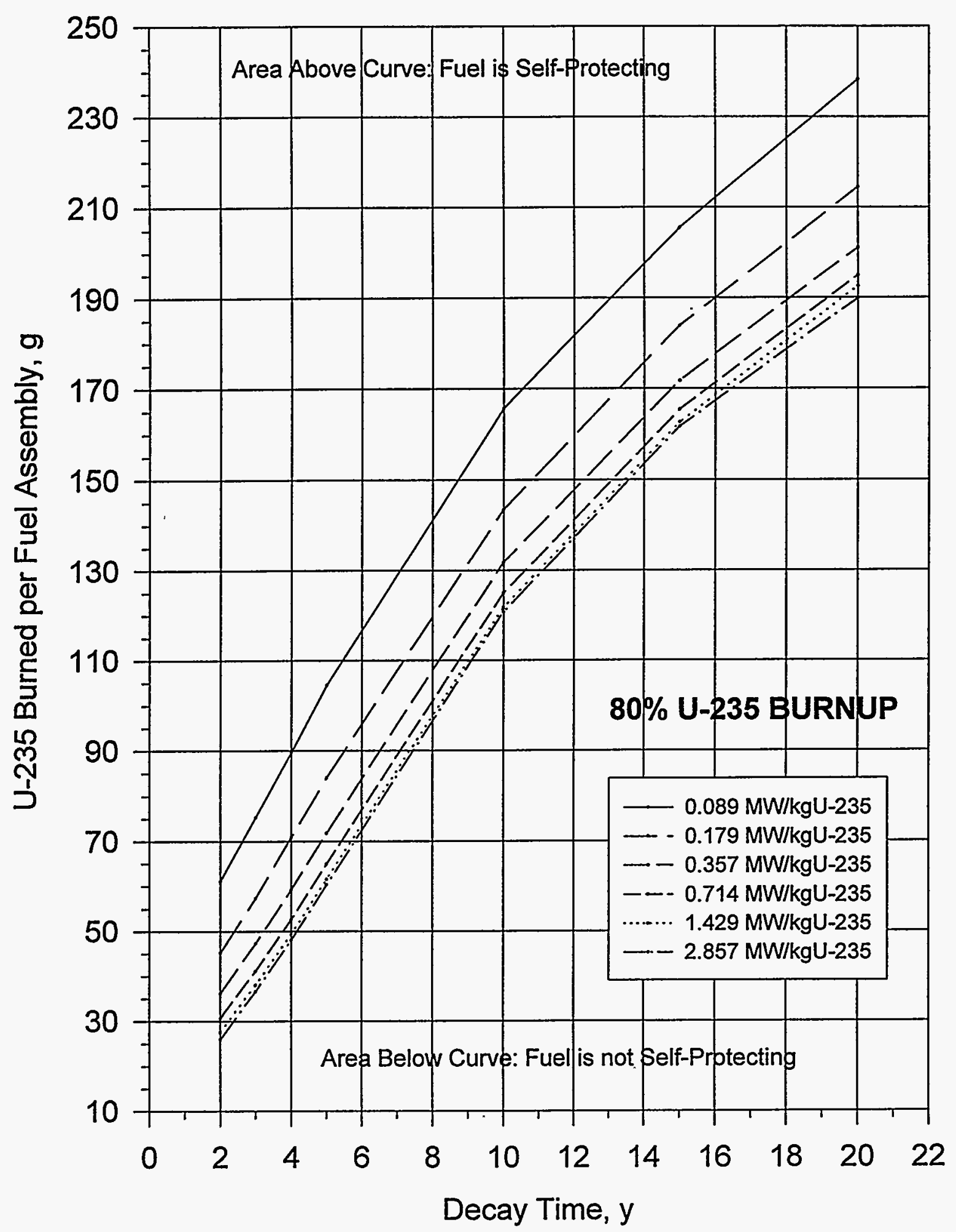

Figure B6. Mass of Burned ${ }^{235} \mathrm{U}$ per Fuel Assembly Necessary for an Unshielded $100 \mathrm{rem} / \mathrm{h}$ Dose Rate at $1 \mathrm{~m}$ for a Fuel Assembly with $80 \%{ }^{235} \mathrm{U}$ Burnup and Power Densities from 0.089 to $2.857 \mathrm{MW} / \mathrm{kg}^{235} \mathrm{U}$ 
Table B1. Reference" Material Data

\begin{tabular}{|c|c|c|c|c|c|}
\hline Material & $\begin{array}{l}\text { Decay } \\
\text { Constant, } \\
\mathrm{s}^{-1}\end{array}$ & $\begin{array}{l}\text { Fission } \\
\text { Product } \\
\text { Yield, \% }\end{array}$ & $\begin{array}{l}\text { Capture } \\
\text { Cross } \\
\text { Section, b }\end{array}$ & $\begin{array}{l}\text { Energy } \\
\text { Group, } \\
\text { MeV }\end{array}$ & $\begin{array}{l}\text { Photons/ } \\
\text { Disinte- } \\
\text { gration }\end{array}$ \\
\hline${ }^{90} \mathrm{Sr}$ & $7.816-10$ & 5.8 & 1.028 & $\begin{array}{l}0.30 \\
0.63 \\
\end{array}$ & $\begin{array}{l}4 \cdot 69-3 \\
4.39-6\end{array}$ \\
\hline${ }^{90} \mathrm{Y}$ & $3.005-6$ & small & 2.740 & $\begin{array}{l}0.30 \\
0.63 \\
1.10 \\
\end{array}$ & $\begin{array}{l}4.94-2 \\
1.62-2 \\
2.48-3\end{array}$ \\
\hline${ }^{95} \mathrm{Zr}$ & $1.225-7$ & 6.50 & 0.0 & 0.63 & 1.15 \\
\hline${ }^{95} \mathrm{Nb}$ & $2.285-7$ & small & 3.563 & 0.63 & 1.22 \\
\hline${ }^{106} \mathrm{Ru}$ & $2.174-8$ & 0.401 & 0.4550 & & none \\
\hline${ }^{106} \mathrm{Rh}$ & $2.318-2$ & small & 0.0 & $\begin{array}{l}0.30 \\
0.63 \\
1.10 \\
\end{array}$ & $\begin{array}{l}1.53-1 \\
3.43-1 \\
5.20-2\end{array}$ \\
\hline${ }^{133} \mathrm{Cs}$ & stable & 6.69 & 103.2 & & none \\
\hline${ }^{134} \mathrm{Cs}$ & $1.066-8$ & small & 107.1 & $\begin{array}{l}0.63 \\
1.10 \\
\end{array}$ & $\begin{array}{l}2.40 \\
3.10-2 \\
\end{array}$ \\
\hline${ }^{137} \mathrm{Cs}$ & $7.297-10$ & 6.19 & 0.1310 & $\begin{array}{l}0.30 \\
0.63 \\
\end{array}$ & $\begin{array}{l}1.01-2 \\
4.24-5 \\
\end{array}$ \\
\hline${ }^{137 m_{\mathrm{Ba}}}$ & $4.530-3$ & small & 0.0 & 0.63 & 1.05 \\
\hline${ }^{144} \mathrm{Ce}$ & $2.821-8$ & 5.50 & 1.172 & 0.30 & $1.00-1$ \\
\hline${ }^{144} \mathrm{Pr}$ & $6.684-4$ & $\operatorname{sma} 11$ & 0.0 & $\begin{array}{l}0.30 \\
0.63 \\
1.10 \\
\end{array}$ & $\begin{array}{l}7.53-2 \\
4.32-2 \\
8.67-3 \\
\end{array}$ \\
\hline${ }^{60} \mathrm{Co}$ & $4.176-9$ & none & 4.275 & 1.10 & 2.28 \\
\hline
\end{tabular}

a All data are from Ref. 3, except yield data from Ref. 6. 
Table B2. Photon Flux-to-Dose Conversion Vs. Photon Energy

\begin{tabular}{|c|c|c|c|}
\hline $\begin{array}{l}\text { Photon } \\
\text { Energy, } \\
\text { MeV }\end{array}$ & $\begin{array}{l}\text { Flux-to-Dose } \\
\text { Conversion } \\
10^{-12} \mathrm{~Sv}-\mathrm{Cm}^{2}\end{array}$ & $\begin{array}{l}\text { Photon } \\
\text { Energy, } \\
\text { MeV }\end{array}$ & $\begin{array}{l}\text { Flux-to-Dose } \\
\text { Conversion } \\
10^{-12} \mathrm{sv}-\mathrm{cm}^{2}\end{array}$ \\
\hline 5.25 & 15.2 & 6.0 & 16.7 \\
\hline 4.70 & 14.04 & 5.0 & 14.7 \\
\hline 4.22 & 12.984 & 4.0 & 12.5 \\
\hline 3.70 & 11.81 & 3.0 & 10.2 \\
\hline 3.25 & 10.775 & 2.0 & 7.66 \\
\hline 2.75 & 9.565 & 1.5 & 6.24 \\
\hline 2.38 & 8.6252 & 1.0 & 4.60 \\
\hline 1.99 & 7.6316 & 0.8 & 3.83 \\
\hline 1.55 & 6.382 & 0.6 & 2.99 \\
\hline 1.10 & 4.928 & 0.5 & 2.54 \\
\hline 0.63 & 3.116 & 0.4 & 2.06 \\
\hline 0.30 & 1.56 & 0.3 & 1.56 \\
\hline 0.20 & 1.03 & 0.2 & 1.03 \\
\hline 0.15 & 0.777 & 0.15 & 0.777 \\
\hline 0.10 & 0.533 & 0.10 & 0.533 \\
\hline 0.0625 & 0.406375 & 0.08 & 0.451 \\
\hline 0.0425 & 0.36975 & 0.06 & 0.400 \\
\hline 0.0275 & 0.30625 & 0.05 & 0.384 \\
\hline \multirow[t]{6}{*}{0.0105} & 0.0715 & 0.04 & 0.365 \\
\hline & & 0.03 & 0.329 \\
\hline & & 0.02 & 0.238 \\
\hline & & 0.015 & 0.157 \\
\hline & & 0.01 & 0.062 \\
\hline & & $4.25-3$ & 0.01 \\
\hline
\end{tabular}

a $\mathrm{Sv}-\mathrm{Cm}^{2}=(3.6+5 \mathrm{rem} / \mathrm{h}) /\left(\mathrm{ph} / \mathrm{cm}^{2}-\mathrm{s}\right) ; \mathrm{Gy} \equiv \mathrm{J} / \mathrm{kg} \equiv 100 \mathrm{rem}=\mathrm{sv}$. 
Table B3. Photon Source Rates, ph/s per $\mathrm{g}^{235} \mathrm{U}$ Burned (ORIGEN: All Fission Products)

\begin{tabular}{|c|c|c|c|c|c|c|c|}
\hline \multirow{2}{*}{\multicolumn{2}{|c|}{$\begin{array}{l}\text { Decay } \\
\text { Time, y } \\
\text { Burnup, } \\
{ }_{0}^{2235} U\end{array}$}} & \multicolumn{6}{|c|}{ Assembly Power Density, $\mathrm{MW} / \mathrm{kg}^{235} \mathrm{U}$} \\
\hline & & 2.857 & 1.429 & 0.714 & 0.357 & 0.179 & 0.089 \\
\hline $\begin{array}{l}2 \\
3 \\
4 \\
\end{array}$ & $1 \%$ & $\begin{array}{l}2.93 \mathrm{e} 11 \\
1.70 \mathrm{e} 11 \\
1.28 \mathrm{e} 11\end{array}$ & $\begin{array}{l}2.92 \mathrm{e} 11 \\
1.70 \mathrm{e} 11 \\
1.28 \mathrm{e} 11\end{array}$ & $\begin{array}{l}2.90 \mathrm{e} 11 \\
1.70 \mathrm{e} 11 \\
1.28 \mathrm{e} 11\end{array}$ & $\begin{array}{l}2.87 \mathrm{e} 11 \\
1.69 \mathrm{e} 11 \\
1.28 \mathrm{el1}\end{array}$ & $\begin{array}{l}2.81 \mathrm{el} 1 \\
1.68 \mathrm{e} 11 \\
1.28 \mathrm{e} 11\end{array}$ & $\begin{array}{l}2.69 \mathrm{e} 11 \\
1.65 \mathrm{e} 11 \\
1.26 \mathrm{e} 11 \\
\end{array}$ \\
\hline $\begin{array}{l}2 \\
3 \\
4 \\
\end{array}$ & $10 \%$ & $\begin{array}{l}2.96 \mathrm{e} 11 \\
1.76 \mathrm{e} 11 \\
1.34 \mathrm{e} 11\end{array}$ & $\begin{array}{l}2.92 \mathrm{e} 11 \\
1.77 \mathrm{e} 11 \\
1.34 \mathrm{e} 11\end{array}$ & $\begin{array}{l}2.81 \mathrm{e} 11 \\
1.75 \mathrm{e} 11 \\
1.34 \mathrm{e} 11\end{array}$ & $\begin{array}{l}2.59 \mathrm{e} 11 \\
1.68 \mathrm{e} 11 \\
1.31 \mathrm{e} 11\end{array}$ & $\begin{array}{l}2.27 \mathrm{e} 11 \\
1.56 \mathrm{e} 11 \\
1.25 \mathrm{e} 11\end{array}$ & $\begin{array}{l}1.89 \mathrm{e} 11 \\
1.39 \mathrm{e} 11 \\
1.17 \mathrm{e} 11 \\
\end{array}$ \\
\hline $\begin{array}{r}2 \\
3 \\
4 \\
5 \\
10 \\
15 \\
20 \\
\end{array}$ & $20 \%$ & $\begin{array}{l}3.11 \mathrm{e} 11 \\
1.91 \mathrm{e} 11 \\
1.44 \mathrm{e} 11 \\
1.21 \mathrm{e} 11 \\
8.77 \mathrm{e} 10 \\
7.59 \mathrm{e} 10 \\
6.73 \mathrm{e} 10\end{array}$ & $\begin{array}{l}3.04 \mathrm{e} 11 \\
1.91 \mathrm{e} 11 \\
1.45 \mathrm{e} 11 \\
1.22 \mathrm{e} 11 \\
8.80 \mathrm{e} 10 \\
7.59 \mathrm{e} 10 \\
6.71 \mathrm{e} 10\end{array}$ & $\begin{array}{l}2.82 \mathrm{e} 11 \\
1.84 \mathrm{e} 11 \\
1.43 \mathrm{e} 11 \\
1.21 \mathrm{e} 11 \\
8.79 \mathrm{e} 10 \\
7.57 \mathrm{e} 10 \\
6.70 \mathrm{e} 10\end{array}$ & $\begin{array}{l}2.48 \mathrm{e} 11 \\
1.72 \mathrm{e} 11 \\
1.36 \mathrm{e} 11 \\
1.18 \mathrm{e} 11 \\
8.70 \mathrm{e} 10 \\
7.52 \mathrm{e} 10 \\
6.66 \mathrm{e} 10\end{array}$ & $\begin{array}{l}2.07 \mathrm{e} 11 \\
1.54 \mathrm{e} 11 \\
1.27 \mathrm{e} 11 \\
1.12 \mathrm{e} 11 \\
8.55 \mathrm{e} 10 \\
7.41 \mathrm{e} 10 \\
6.55 \mathrm{e} 10\end{array}$ & $\begin{array}{l}1.67 \mathrm{e} 11 \\
1.33 \mathrm{e} 11 \\
1.15 \mathrm{e} 11 \\
1.05 \mathrm{e} 11 \\
8.25 \mathrm{e} 10 \\
7.20 \mathrm{e} 10 \\
6.38 \mathrm{e} 10\end{array}$ \\
\hline $\begin{array}{r}2 \\
3 \\
4 \\
5 \\
10 \\
15 \\
20 \\
\end{array}$ & $40 \%$ & $\begin{array}{l}3.55 \mathrm{el} 1 \\
2.29 \mathrm{e} 11 \\
1.72 \mathrm{e} 11 \\
1.42 \mathrm{e} 11 \\
9.20 \mathrm{e} 10 \\
7.71 \mathrm{e} 10 \\
6.76 \mathrm{e} 10\end{array}$ & $\begin{array}{l}3.36 \mathrm{e} 11 \\
2.23 \mathrm{e} 11 \\
1.71 \mathrm{e} 11 \\
1.41 \mathrm{e} 11 \\
9.20 \mathrm{e} 10 \\
7.68 \mathrm{e} 10 \\
6.73 \mathrm{e} 10\end{array}$ & $\begin{array}{l}3.01 \mathrm{e} 11 \\
2.10 \mathrm{e} 11 \\
1.63 \mathrm{e} 11 \\
1.38 \mathrm{e} 11 \\
9.11 \mathrm{e} 10 \\
7.63 \mathrm{e} 10 \\
6.68 \mathrm{e} 10\end{array}$ & $\begin{array}{l}2.56 \mathrm{e} 11 \\
1.88 \mathrm{e} 11 \\
1.52 \mathrm{e} 11 \\
1.30 \mathrm{e} 11 \\
8.93 \mathrm{e} 10 \\
7.51 \mathrm{e} 10 \\
6.60 \mathrm{e} 10\end{array}$ & $\begin{array}{l}2.08 \mathrm{e} 11 \\
1.63 \mathrm{e} 11 \\
1.36 \mathrm{e} 11 \\
1.21 \mathrm{e} 11 \\
8.59 \mathrm{e} 10 \\
7.29 \mathrm{e} 10 \\
6.40 \mathrm{e} 10\end{array}$ & $\begin{array}{l}1.63 \mathrm{e} 11 \\
1.35 \mathrm{e} 11 \\
1.18 \mathrm{e} 11 \\
1.06 \mathrm{e} 11 \\
8.02 \mathrm{e} 10 \\
6.88 \mathrm{e} 10 \\
6.06 \mathrm{e} 10\end{array}$ \\
\hline $\begin{array}{r}2 \\
3 \\
4 \\
5 \\
10 \\
15 \\
20 \\
\end{array}$ & $60 \%$ & $\begin{array}{l}4.20 \mathrm{e} 11 \\
2.80 \mathrm{e} 11 \\
2.11 \mathrm{e} 11 \\
1.70 \mathrm{e} 11 \\
9.82 \mathrm{e} 10 \\
7.80 \mathrm{e} 10 \\
6.79 \mathrm{e} 10\end{array}$ & $\begin{array}{l}3.92 \mathrm{e} 11 \\
2.70 \mathrm{e} 11 \\
2.06 \mathrm{e} 11 \\
1.68 \mathrm{e} 11 \\
9.76 \mathrm{e} 10 \\
7.80 \mathrm{e} 10 \\
6.79 \mathrm{e} 10\end{array}$ & $\begin{array}{l}3.48 \mathrm{e} 11 \\
2.50 \mathrm{e} 11 \\
1.95 \mathrm{e} 11 \\
1.61 \mathrm{e} 11 \\
9.58 \mathrm{e} 10 \\
7.68 \mathrm{e} 10 \\
6.73 \mathrm{e} 10\end{array}$ & $\begin{array}{l}2.90 \mathrm{e} 11 \\
2.19 \mathrm{e} 11 \\
1.76 \mathrm{e} 11 \\
1.49 \mathrm{e} 11 \\
9.23 \mathrm{e} 10 \\
7.50 \mathrm{e} 10 \\
6.55 \mathrm{e} 10\end{array}$ & $\begin{array}{l}2.32 \mathrm{el1} \\
1.83 \mathrm{e} 11 \\
1.52 \mathrm{e} 11 \\
1.32 \mathrm{e} 11 \\
8.75 \mathrm{e} 10 \\
7.20 \mathrm{e} 10 \\
6.25 \mathrm{e} 10 \\
\end{array}$ & $\begin{array}{l}1.76 \mathrm{e} 11 \\
1.45 \mathrm{e} 11 \\
1.25 \mathrm{e} 11 \\
1.11 \mathrm{e} 11 \\
7.86 \mathrm{e} 10 \\
6.61 \mathrm{e} 10 \\
5.77 \mathrm{e} 10 \\
\end{array}$ \\
\hline $\begin{array}{r}2 \\
3 \\
4 \\
5 \\
10 \\
15 \\
20\end{array}$ & $80 \%$ & $\begin{array}{l}5.27 \mathrm{e} 11 \\
3.62 \mathrm{e} 11 \\
2.71 \mathrm{e} 11 \\
2.14 \mathrm{e} 11 \\
1.07 \mathrm{e} 11 \\
8.04 \mathrm{e} 10 \\
6.88 \mathrm{e} 10 \\
\end{array}$ & $\begin{array}{l}4.91 \mathrm{e} 11 \\
3.46 \mathrm{e} 11 \\
2.63 \mathrm{e} 11 \\
2.09 \mathrm{e} 11 \\
1.06 \mathrm{e} 11 \\
7.99 \mathrm{e} 10 \\
6.79 \mathrm{e} 10\end{array}$ & $\begin{array}{l}4.34 \mathrm{e} 11 \\
3.17 \mathrm{e} 11 \\
2.45 \mathrm{e} 11 \\
1.97 \mathrm{e} 11 \\
1.03 \mathrm{e} 11 \\
7.86 \mathrm{e} 10 \\
6.70 \mathrm{e} 10\end{array}$ & $\begin{array}{l}3.63 \mathrm{e} 11 \\
2.74 \mathrm{e} 11 \\
2.17 \mathrm{e} 11 \\
1.78 \mathrm{e} 11 \\
9.82 \mathrm{e} 10 \\
7.59 \mathrm{e} 10 \\
6.52 \mathrm{e} 10\end{array}$ & $\begin{array}{l}2.86 \mathrm{el} 1 \\
2.24 \mathrm{e} 11 \\
1.82 \mathrm{e} 11 \\
1.53 \mathrm{e} 11 \\
9.02 \mathrm{e} 10 \\
7.10 \mathrm{e} 10 \\
6.12 \mathrm{e} 10\end{array}$ & $\begin{array}{l}2.11 \mathrm{el1} \\
1.71 \mathrm{e} 11 \\
1.43 \mathrm{e} 11 \\
1.23 \mathrm{e} 11 \\
7.81 \mathrm{e} 10 \\
6.34 \mathrm{e} 10 \\
5.49 \mathrm{e} 10\end{array}$ \\
\hline
\end{tabular}


Table B4. Photon Source Rates, ph/s per $\mathrm{g}^{235} \mathrm{U}$ Burned (FP's: ${ }^{90} \mathrm{Sr}{ }^{90} \mathrm{Y}{ }^{95} \mathrm{Zr}{ }^{95} \mathrm{Nb}{ }^{106} \mathrm{Rh}{ }^{134} \mathrm{Cs} \quad{ }^{137} \mathrm{Cs}{ }^{137 m} \mathrm{Ba}{ }^{144} \mathrm{Ce}{ }^{144} \mathrm{Pr}$ )

\begin{tabular}{|c|c|c|c|c|c|c|c|}
\hline \multirow{2}{*}{\multicolumn{2}{|c|}{$\begin{array}{l}\text { Decay } \\
\text { Time, y } \\
\text { Burnup, } \\
g^{235} \mathrm{U}\end{array}$}} & \multicolumn{6}{|c|}{ Assembly Power Density, $\mathrm{MW} / \mathrm{kg}^{235} \mathrm{U}$} \\
\hline & & 2.857 & 1.429 & 0.714 & 0.357 & 0.179 & 0.089 \\
\hline $\begin{array}{l}2 \\
3 \\
4 \\
\end{array}$ & $1 \%$ & $\begin{array}{l}2.90 \mathrm{e} 11 \\
1.71 \mathrm{e} 11 \\
1.30 \mathrm{e} 11\end{array}$ & $\begin{array}{l}2.89 e 11 \\
1.70 \mathrm{e} 11 \\
1.30 \mathrm{e} 11\end{array}$ & $\begin{array}{l}2.87 \mathrm{e} 11 \\
1.70 \mathrm{e} 11 \\
1.30 \mathrm{e} 11\end{array}$ & $\begin{array}{l}2.83 \mathrm{e} 11 \\
1.69 \mathrm{e} 11 \\
1.29 \mathrm{e} 11\end{array}$ & $\begin{array}{l}2.77 \mathrm{e} 11 \\
1.67 \mathrm{e} 11 \\
1.28 \mathrm{e} 11\end{array}$ & $\begin{array}{l}2.65 \mathrm{e} 11 \\
1.64 \mathrm{e} 11 \\
1.27 \mathrm{e} 11\end{array}$ \\
\hline $\begin{array}{l}2 \\
3 \\
4 \\
\end{array}$ & $10 \%$ & $\begin{array}{l}3.01 \mathrm{e} 11 \\
1.82 \mathrm{e} 11 \\
1.39 \mathrm{e} 11\end{array}$ & $\begin{array}{l}2.92 \mathrm{e} 11 \\
1.80 \mathrm{e} 11 \\
1.38 \mathrm{e} 11 \\
\end{array}$ & $\begin{array}{l}2.78 \mathrm{e} 11 \\
1.76 \mathrm{e} 11 \\
1.36 \mathrm{e} 11 \\
\end{array}$ & $\begin{array}{l}2.56 \mathrm{e} 11 \\
1.68 \mathrm{e} 11 \\
1.32 \mathrm{e} 11 \\
\end{array}$ & $\begin{array}{l}2.24 \mathrm{e} 11 \\
1.56 \mathrm{e} 11 \\
1.26 \mathrm{e} 11\end{array}$ & $\begin{array}{l}1.87 \mathrm{e} 11 \\
1.40 \mathrm{e} 11 \\
1.18 \mathrm{e} 11\end{array}$ \\
\hline $\begin{array}{r}2 \\
3 \\
4 \\
5 \\
10 \\
15 \\
20 \\
\end{array}$ & $20 \%$ & $\begin{array}{l}3.16 \mathrm{e} 11 \\
1.97 \mathrm{e} 11 \\
1.50 \mathrm{e} 11 \\
1.26 \mathrm{e} 11 \\
9.07 \mathrm{e} 10 \\
7.85 \mathrm{e} 10 \\
6.95 \mathrm{e} 10 \\
\end{array}$ & $\begin{array}{l}3.01 \mathrm{e} 11 \\
1.92 \mathrm{e} 11 \\
1.47 \mathrm{e} 11 \\
1.25 \mathrm{e} 11 \\
9.05 \mathrm{e} 10 \\
7.83 \mathrm{e} 10 \\
6.94 \mathrm{e} 10 \\
\end{array}$ & $\begin{array}{l}2.78 \mathrm{e} 11 \\
1.84 \mathrm{e} 11 \\
1.44 \mathrm{e} 11 \\
1.23 \mathrm{e} 11 \\
9.00 \mathrm{e} 10 \\
7.80 \mathrm{e} 10 \\
6.91 \mathrm{e} 10 \\
\end{array}$ & $\begin{array}{l}2.45 \mathrm{e} 11 \\
1.71 \mathrm{e} 11 \\
1.37 \mathrm{e} 11 \\
1.19 \mathrm{e} 11 \\
8.92 \mathrm{e} 10 \\
7.75 \mathrm{e} 10 \\
6.87 \mathrm{e} 10 \\
\end{array}$ & $\begin{array}{l}2.05 \mathrm{el} 1 \\
1.53 \mathrm{e} 11 \\
1.28 \mathrm{e} 11 \\
1.14 \mathrm{e} 11 \\
8.77 \mathrm{e} 10 \\
7.63 \mathrm{e} 10 \\
6.77 \mathrm{e} 10 \\
\end{array}$ & $\begin{array}{l}1.66 \mathrm{e} 11 \\
1.33 \mathrm{e} 11 \\
1.16 \mathrm{e} 11 \\
1.06 \mathrm{e} 11 \\
8.48 \mathrm{e} 10 \\
7.42 \mathrm{e} 10 \\
6.58 \mathrm{e} 10 \\
\end{array}$ \\
\hline $\begin{array}{r}2 \\
3 \\
4 \\
5 \\
10 \\
15 \\
20 \\
\end{array}$ & $40 \%$ & $\begin{array}{l}3.57 \mathrm{e} 11 \\
2.32 \mathrm{e} 11 \\
1.76 \mathrm{e} 11 \\
1.45 \mathrm{e} 11 \\
9.43 \mathrm{e} 10 \\
7.90 \mathrm{e} 10 \\
6.95 \mathrm{e} 10 \\
\end{array}$ & $\begin{array}{l}3.32 \mathrm{e} 11 \\
2.23 \mathrm{e} 11 \\
1.71 \mathrm{e} 11 \\
1.42 \mathrm{e} 11 \\
9.37 \mathrm{e} 10 \\
7.87 \mathrm{e} 10 \\
6.93 \mathrm{e} 10 \\
\end{array}$ & $\begin{array}{l}2.97 \mathrm{e} 11 \\
2.08 \mathrm{e} 11 \\
1.63 \mathrm{e} 11 \\
1.38 \mathrm{e} 11 \\
9.27 \mathrm{e} 10 \\
7.81 \mathrm{e} 10 \\
6.88 \mathrm{e} 10 \\
\end{array}$ & $\begin{array}{l}2.52 \mathrm{el1} \\
1.86 \mathrm{e} 11 \\
1.51 \mathrm{e} 11 \\
1.30 \mathrm{e} 11 \\
9.08 \mathrm{e} 10 \\
7.69 \mathrm{e} 10 \\
6.78 \mathrm{e} 10 \\
\end{array}$ & $\begin{array}{l}2.04 \mathrm{e} 11 \\
1.60 \mathrm{e} 11 \\
1.36 \mathrm{e} 11 \\
1.20 \mathrm{e} 11 \\
8.74 \mathrm{e} 10 \\
7.46 \mathrm{e} 10 \\
6.59 \mathrm{e} 10 \\
\end{array}$ & $\begin{array}{l}1.61 \mathrm{e} 11 \\
1.34 \mathrm{e} 11 \\
1.18 \mathrm{e} 11 \\
1.07 \mathrm{e} 11 \\
8.16 \mathrm{e} 10 \\
7.04 \mathrm{e} 10 \\
6.23 \mathrm{e} 10 \\
\end{array}$ \\
\hline $\begin{array}{r}2 \\
3 \\
4 \\
5 \\
10 \\
15 \\
20 \\
\end{array}$ & $60 \%$ & $\begin{array}{l}4.19 e 11 \\
2.81 \mathrm{e} 11 \\
2.12 \mathrm{e} 11 \\
1.71 \mathrm{e} 11 \\
9.91 \mathrm{e} 10 \\
7.98 \mathrm{e} 10 \\
6.96 \mathrm{e} 10 \\
\end{array}$ & $\begin{array}{l}3.85 \mathrm{e} 11 \\
2.66 \mathrm{e} 11 \\
2.04 \mathrm{e} 11 \\
1.66 \mathrm{e} 11 \\
9.81 \mathrm{e} 10 \\
7.93 \mathrm{e} 10 \\
6.92 \mathrm{e} 10 \\
\end{array}$ & $\begin{array}{l}3.38 \mathrm{e} 11 \\
2.44 \mathrm{e} 11 \\
1.91 \mathrm{e} 11 \\
1.58 \mathrm{e} 11 \\
9.63 \mathrm{e} 10 \\
7.83 \mathrm{e} 10 \\
6.84 \mathrm{e} 10 \\
\end{array}$ & $\begin{array}{l}2.82 \mathrm{e} 11 \\
2.13 \mathrm{e} 11 \\
1.73 \mathrm{e} 11 \\
1.46 \mathrm{e} 11 \\
9.30 \mathrm{e} 10 \\
7.65 \mathrm{e} 10 \\
6.70 \mathrm{e} 10 \\
\end{array}$ & $\begin{array}{l}2.25 \mathrm{e} 11 \\
1.78 \mathrm{e} 11 \\
1.49 \mathrm{e} 11 \\
1.30 \mathrm{e} 11 \\
8.75 \mathrm{e} 10 \\
7.31 \mathrm{e} 10 \\
6.42 \mathrm{e} 10 \\
\end{array}$ & $\begin{array}{l}1.71 \mathrm{e} 11 \\
1.42 \mathrm{e} 11 \\
1.23 \mathrm{e} 11 \\
1.10 \mathrm{e} 11 \\
7.90 \mathrm{e} 10 \\
6.70 \mathrm{e} 10 \\
5.91 \mathrm{e} 10 \\
\end{array}$ \\
\hline $\begin{array}{r}2 \\
3 \\
4 \\
5 \\
10 \\
15 \\
20\end{array}$ & $80 \%$ & $\begin{array}{l}5.14 \mathrm{e} 11 \\
3.52 \mathrm{e} 11 \\
2.64 \mathrm{e} 11 \\
2.09 \mathrm{e} 11 \\
1.06 \mathrm{e} 11 \\
8.10 \mathrm{e} 10 \\
6.97 \mathrm{e} 10\end{array}$ & $\begin{array}{l}4.70 \mathrm{e} 11 \\
3.32 \mathrm{e} 11 \\
2.52 \mathrm{e} 11 \\
2.01 \mathrm{e} 11 \\
1.04 \mathrm{e} 11 \\
8.03 \mathrm{e} 10 \\
6.92 \mathrm{e} 10\end{array}$ & $\begin{array}{l}4.12 \mathrm{e} 11 \\
3.00 \mathrm{e} 11 \\
2.33 \mathrm{e} 11 \\
1.89 \mathrm{e} 11 \\
1.02 \mathrm{e} 11 \\
7.89 \mathrm{e} 10 \\
6.81 \mathrm{e} 10\end{array}$ & $\begin{array}{l}3.42 \mathrm{e} 11 \\
2.59 \mathrm{e} 11 \\
2.06 \mathrm{e} 11 \\
1.70 \mathrm{e} 11 \\
9.67 \mathrm{e} 10 \\
7.64 \mathrm{e} 10 \\
6.62 \mathrm{e} 10\end{array}$ & $\begin{array}{l}2.69 \mathrm{e} 11 \\
2.11 \mathrm{e} 11 \\
1.73 \mathrm{e} 11 \\
1.46 \mathrm{e} 11 \\
8.89 \mathrm{e} 10 \\
7.18 \mathrm{e} 10 \\
6.26 \mathrm{e} 10\end{array}$ & $\begin{array}{l}1.98 \mathrm{e} 11 \\
1.61 \mathrm{e} 11 \\
1.36 \mathrm{e} 11 \\
1.18 \mathrm{e} 11 \\
7.75 \mathrm{e} 10 \\
6.40 \mathrm{e} 10 \\
5.61 \mathrm{e} 10\end{array}$ \\
\hline
\end{tabular}


Table B5. Photon Dose Rates in Air, rem/h per $g^{235} \mathrm{U}$ Burned (ORIGEN: All Fission Products - Sievert Integral)

(Line-source Model Dose Rates)

\begin{tabular}{|c|c|c|c|c|c|c|c|}
\hline \multirow{2}{*}{\multicolumn{2}{|c|}{$\begin{array}{l}\text { Decay } \\
\text { Time, y } \\
\text { Burnup, } \\
\text { : }^{235} \mathrm{U}\end{array}$}} & \multicolumn{6}{|c|}{ Assembly Power Density, $\mathrm{MW} / \mathrm{kg}^{235} \mathrm{U}$} \\
\hline & & 2.857 & 1.429 & 0.714 & 0.357 & 0.179 & 0.089 \\
\hline $\begin{array}{l}2 \\
3 \\
4\end{array}$ & $1 \%$ & $\begin{array}{l}2.16+0 \\
1.30+0 \\
1.02+0\end{array}$ & $\begin{array}{l}2.16+0 \\
1.30+0 \\
1.02+0\end{array}$ & $\begin{array}{l}2.15+0 \\
1.30+0 \\
1.02+0\end{array}$ & $\begin{array}{l}2.12+0 \\
1.30+0 \\
1.02+0\end{array}$ & $\begin{array}{l}2.08+0 \\
1.29+0 \\
1.02+0\end{array}$ & $\begin{array}{l}1.99+0 \\
1.27+0 \\
1.01+0\end{array}$ \\
\hline $\begin{array}{l}2 \\
3 \\
4 \\
\end{array}$ & $10 \%$ & $\begin{array}{l}2.21+0 \\
1.36+0 \\
1.07+0\end{array}$ & $\begin{array}{l}2.18+0 \\
1.37+0 \\
1.08+0\end{array}$ & $\begin{array}{l}2.11+0 \\
1.37+0 \\
1.08+0\end{array}$ & $\begin{array}{l}1.95+0 \\
1.32+0 \\
1.07+0\end{array}$ & $\begin{array}{l}1.73+0 \\
1.24+0 \\
1.02+0\end{array}$ & $\begin{array}{l}1.47+0 \\
1.12+0 \\
9.63-1\end{array}$ \\
\hline $\begin{array}{r}2 \\
3 \\
4 \\
5 \\
10 \\
15 \\
20\end{array}$ & $20 \%$ & $\begin{array}{l}2 \cdot 34+0 \\
1 \cdot 49+0 \\
1 \cdot 17+0 \\
9 \cdot 99-1 \\
7 \cdot 37-1 \\
6 \cdot 38-1 \\
5 \cdot 65-1\end{array}$ & $\begin{array}{l}2.30+0 \\
1.50+0 \\
1.18+0 \\
1.01+0 \\
7.40-1 \\
6.38-1 \\
5.64-1\end{array}$ & $\begin{array}{l}2.16+0 \\
1.46+0 \\
1.17+0 \\
1.01+0 \\
7.38-1 \\
6.37-1 \\
5.62-1\end{array}$ & $\begin{array}{l}1 \cdot 92+0 \\
1.38+0 \\
1 \cdot 12+0 \\
9 \cdot 83-1 \\
7 \cdot 32-1 \\
6 \cdot 32-1 \\
5 \cdot 59-1\end{array}$ & $\begin{array}{l}1.64+0 \\
1.25+0 \\
1.05+0 \\
9.40-1 \\
7.19-1 \\
6.22-1 \\
5.51-1\end{array}$ & $\begin{array}{l}1.35+0 \\
1.10+0 \\
9.64-1 \\
8.81-1 \\
6.94-1 \\
6.05-1 \\
5.35-1\end{array}$ \\
\hline $\begin{array}{r}2 \\
3 \\
4 \\
5 \\
10 \\
15 \\
20 \\
\end{array}$ & $40 \%$ & $\begin{array}{l}2 \cdot 76+0 \\
1.84+0 \\
1.42+0 \\
1.19+0 \\
7 \cdot 77-1 \\
6.49-1 \\
5.68-1\end{array}$ & $\begin{array}{l}2.63+0 \\
1.81+0 \\
1.42+0 \\
1.18+0 \\
7.78-1 \\
6.47-1 \\
5.66-1 \\
\end{array}$ & $\begin{array}{l}2 \cdot 39+0 \\
1.72+0 \\
1.37+0 \\
1.16+0 \\
7 \cdot 70-1 \\
6.42-1 \\
5.62-1\end{array}$ & $\begin{array}{l}2.07+0 \\
1.56+0 \\
1.28+0 \\
1.10+0 \\
7.55-1 \\
6.32-1 \\
5.55-1\end{array}$ & $\begin{array}{l}1 \cdot 71+0 \\
1 \cdot 36+0 \\
1 \cdot 16+0 \\
1.02+0 \\
7 \cdot 25-1 \\
6.14-1 \\
5.39-1\end{array}$ & $\begin{array}{l}1.36+0 \\
1.14+0 \\
9.97-1 \\
8.99-1 \\
6.77-1 \\
5.79-1 \\
5.10-1\end{array}$ \\
\hline $\begin{array}{r}2 \\
3 \\
4 \\
5 \\
10 \\
15 \\
20 \\
\end{array}$ & $60 \%$ & $\begin{array}{l}3.36+0 \\
2.31+0 \\
1.77+0 \\
1.44+0 \\
8.33-1 \\
6.61-1 \\
5.72-1 \\
\end{array}$ & $\begin{array}{l}3.17+0 \\
2.24+0 \\
1.74+0 \\
1.43+0 \\
8.28-1 \\
6.61-1 \\
5.72-1 \\
\end{array}$ & $\begin{array}{l}2.85+0 \\
2.09+0 \\
1.65+0 \\
1.37+0 \\
8.12-1 \\
6.50-1 \\
5.66-1 \\
\end{array}$ & $\begin{array}{l}2.42+0 \\
1.85+0 \\
1.50+0 \\
1.27+0 \\
7.85-1 \\
6.34-1 \\
5.50-1 \\
\end{array}$ & $\begin{array}{l}1.95+0 \\
1.56+0 \\
1.30+0 \\
1.13+0 \\
7.41-1 \\
6.07-1 \\
5 \cdot 29-1\end{array}$ & $\begin{array}{l}1.49+0 \\
1.24+0 \\
1.07+0 \\
9.44-1 \\
6.65-1 \\
5.58-1 \\
4.87-1\end{array}$ \\
\hline $\begin{array}{r}2 \\
3 \\
4 \\
5 \\
10 \\
15 \\
20\end{array}$ & $80 \%$ & $\begin{array}{l}4.35+0 \\
3.05+0 \\
2.31+0 \\
1.83+0 \\
9.15-1 \\
6.83-1 \\
5.80-1 \\
\end{array}$ & $\begin{array}{l}4.08+0 \\
2 \cdot 93+0 \\
2.25+0 \\
1.80+0 \\
9 \cdot 05-1 \\
6.78-1 \\
5 \cdot 76-1\end{array}$ & $\begin{array}{l}3.65+0 \\
2.70+0 \\
2.10+0 \\
1.70+0 \\
8.81-1 \\
6.66-1 \\
5.67-1\end{array}$ & $\begin{array}{l}3.09+0 \\
2.35+0 \\
1.87+0 \\
1.54+0 \\
8.39-1 \\
6.45-1 \\
5.51-1\end{array}$ & $\begin{array}{l}2.45+0 \\
1.93+0 \\
1.57+0 \\
1.32+0 \\
7.70-1 \\
6.04-1 \\
5.18-1\end{array}$ & $\begin{array}{l}1.82+0 \\
1.47+0 \\
1.23+0 \\
1.06+0 \\
6.68-1 \\
5.39-1 \\
4.66-1\end{array}$ \\
\hline
\end{tabular}


Table B6. Photon Dose Rates in Air, rem/h per $g^{235} \mathrm{U}$ Burned (FP's: ${ }^{90} \mathrm{Sr}{ }^{90} \mathrm{Y}{ }^{95} \mathrm{Zr}{ }^{95} \mathrm{Nb}{ }^{106} \mathrm{Rh}{ }^{134} \mathrm{Cs}{ }^{137} \mathrm{Cs}{ }^{137 \mathrm{~m}} \mathrm{Ba}{ }^{144} \mathrm{Ce}{ }^{144} \mathrm{Pr}$ )

(Line-Source Model Dose Rates)

\begin{tabular}{|c|c|c|c|c|c|c|c|}
\hline \multirow{2}{*}{\multicolumn{2}{|c|}{$\begin{array}{l}\text { Decay } \\
\text { Time, y } \\
\text { Burnup, } \\
\%^{235} \mathrm{U}\end{array}$}} & \multicolumn{6}{|c|}{ Assembly Power Density, $M W / \mathrm{kg}^{235} \mathrm{U}$} \\
\hline & & 2.857 & 1.429 & 0.714 & 0.357 & 0.179 & 0.089 \\
\hline $\begin{array}{l}2 \\
3 \\
4\end{array}$ & $1 \%$ & $\begin{array}{l}2.05+0 \\
1.28+0 \\
1.03+0\end{array}$ & $\begin{array}{l}2.05+0 \\
1.27+0 \\
1.02+0\end{array}$ & $\begin{array}{l}2.04+0 \\
1.27+0 \\
1.02+0\end{array}$ & $\begin{array}{l}2.01+0 \\
1.27+0 \\
1.02+0\end{array}$ & $\begin{array}{l}1.96+0 \\
1.25+0 \\
1.02+0\end{array}$ & $\begin{array}{l}1.88+0 \\
1.23+0 \\
1.01+0\end{array}$ \\
\hline $\begin{array}{l}2 \\
3 \\
4\end{array}$ & $10 \%$ & $\begin{array}{l}2 \cdot 16+0 \\
1 \cdot 38+0 \\
1 \cdot 10+0\end{array}$ & $\begin{array}{l}2.11+0 \\
1.37+0 \\
1.10+0\end{array}$ & $\begin{array}{l}2.01+0 \\
1.34+0 \\
1.08+0\end{array}$ & $\begin{array}{l}1.86+0 \\
1.29+0 \\
1.06+0\end{array}$ & $\begin{array}{l}1.65+0 \\
1.22+0 \\
1.02+0\end{array}$ & $\begin{array}{l}1.42+0 \\
1.11+0 \\
9.69-1\end{array}$ \\
\hline $\begin{array}{r}2 \\
3 \\
4 \\
5 \\
10 \\
15 \\
20 \\
\end{array}$ & $20 \%$ & $\begin{array}{l}2.31+0 \\
1.51+0 \\
1.20+0 \\
1.04+0 \\
7.62-1 \\
6.59-1 \\
5.84-1 \\
\end{array}$ & $\begin{array}{l}2.21+0 \\
1.48+0 \\
1.19+0 \\
1.03+0 \\
7.60-1 \\
6.58-1 \\
5.83-1 \\
\end{array}$ & $\begin{array}{l}2.05+0 \\
1.43+0 \\
1.16+0 \\
1.01+0 \\
7.57-1 \\
6.56-1 \\
5.81-1 \\
\end{array}$ & $\begin{array}{l}1.84+0 \\
1.35+0 \\
1.12+0 \\
9.87-1 \\
7.50-1 \\
6.51-1 \\
5.77-1 \\
\end{array}$ & $\begin{array}{l}1.58+0 \\
1.23+0 \\
1.05+0 \\
9.47-1 \\
7.37-1 \\
6.41-1 \\
5.69-1 \\
\end{array}$ & $\begin{array}{l}1.32+0 \\
1.09+0 \\
9.67-1 \\
8.89-1 \\
7.13-1 \\
6.23-1 \\
5.53-1\end{array}$ \\
\hline $\begin{array}{r}2 \\
3 \\
4 \\
5 \\
10 \\
15 \\
20 \\
\end{array}$ & $40 \%$ & $\begin{array}{l}2.69+0 \\
1.83+0 \\
1.44+0 \\
1.20+0 \\
7.93-1 \\
6.64-1 \\
5.84-1 \\
\end{array}$ & $\begin{array}{l}2.52+0 \\
1.77+0 \\
1.40+0 \\
1.19+0 \\
7.89-1 \\
6.62-1 \\
5.82-1 \\
\end{array}$ & $\begin{array}{l}2 \cdot 28+0 \\
1 \cdot 67+0 \\
1 \cdot 34+0 \\
1 \cdot 15+0 \\
7 \cdot 80-1 \\
6 \cdot 56-1 \\
5 \cdot 78-1 \\
\end{array}$ & $\begin{array}{l}1.98+0 \\
1.51+0 \\
1.26+0 \\
1.09+0 \\
7.64-1 \\
6.46-1 \\
5.70-1 \\
\end{array}$ & $\begin{array}{l}1.65+0 \\
1.33+0 \\
1.14+0 \\
1.01+0 \\
7.35-1 \\
6.27-1 \\
5.54-1 \\
\end{array}$ & $\begin{array}{l}1 \cdot 32+0 \\
1 \cdot 12+0 \\
9 \cdot 88-1 \\
8 \cdot 99-1 \\
6 \cdot 87-1 \\
5 \cdot 92-1 \\
5 \cdot 24-1\end{array}$ \\
\hline $\begin{array}{r}2 \\
3 \\
4 \\
5 \\
10 \\
15 \\
20 \\
\end{array}$ & $60 \%$ & $\begin{array}{l}3.25+0 \\
2.26+0 \\
1.75+0 \\
1.43+0 \\
8.35-1 \\
6.71-1 \\
5.85-1 \\
\end{array}$ & $\begin{array}{l}3.02+0 \\
2.16+0 \\
1.69+0 \\
1.40+0 \\
8.27-1 \\
6.67-1 \\
5.81-1 \\
\end{array}$ & $\begin{array}{l}2.70+0 \\
2 \cdot 00+0 \\
1.59+0 \\
1.33+0 \\
8.11-1 \\
6.59-1 \\
5.75-1 \\
\end{array}$ & $\begin{array}{l}2.30+0 \\
1.77+0 \\
1.45+0 \\
1.23+0 \\
7.84-1 \\
6.43-1 \\
5.63-1\end{array}$ & $\begin{array}{l}1.86+0 \\
1.49+0 \\
1.26+0 \\
1.10+0 \\
7.37-1 \\
6.14-1 \\
5.39-1\end{array}$ & $\begin{array}{l}1.43+0 \\
1.20+0 \\
1.04-1 \\
9.26-1 \\
6.65-1 \\
5.63-1 \\
4.97-1\end{array}$ \\
\hline $\begin{array}{r}2 \\
3 \\
4 \\
5 \\
10 \\
15 \\
20 \\
\end{array}$ & $80 \%$ & $\begin{array}{l}4.10+0 \\
2.89+0 \\
2.21+0 \\
1.76+0 \\
8.96-1 \\
6.81-1 \\
5.86-1 \\
\end{array}$ & $\begin{array}{l}3.79+0 \\
2.74+0 \\
2.12+0 \\
1.70+0 \\
8.83-1 \\
6.75-1 \\
5.81-1 \\
\end{array}$ & $\begin{array}{l}3 \cdot 37+0 \\
2 \cdot 51+0 \\
1 \cdot 97+0 \\
1 \cdot 60+0 \\
8 \cdot 58-1 \\
6.64-1 \\
5 \cdot 73-1 \\
\end{array}$ & $\begin{array}{l}2.85+0 \\
2.18+0 \\
1.75+0 \\
1.45+0 \\
8.17-1 \\
6.42-1 \\
5.56-1 \\
\end{array}$ & $\begin{array}{l}2.26+0 \\
1.79+0 \\
1.47+0 \\
1.24+0 \\
7.50-1 \\
6.04-1 \\
5.26-1 \\
\end{array}$ & $\begin{array}{l}1.67+0 \\
1.36+0 \\
1.15+0 \\
9.98-1 \\
6.53-1 \\
5.38-1 \\
4.72-1\end{array}$ \\
\hline
\end{tabular}


Table B7. ${ }^{60} \mathrm{Co}$ Dose Rates in Air, rem/h per $\mathrm{kg}$ per ppm ${ }^{59} \mathrm{Co}$ (Line-Source Model Dose Rates)

\begin{tabular}{|c|c|c|c|c|c|c|c|}
\hline \multirow{2}{*}{\multicolumn{2}{|c|}{$\begin{array}{l}\text { Decay } \\
\text { Time, y } \\
\text { Burnup, } \\
\frac{\circ}{\circ}{ }^{235} \mathrm{U}\end{array}$}} & \multicolumn{6}{|c|}{ Assembly Power Density, $\mathrm{MW} / \mathrm{kg}^{235} \mathrm{U}$} \\
\hline & & 2.857 & 1.429 & 0.714 & 0.357 & 0.179 & 0.089 \\
\hline $\begin{array}{l}2 \\
3 \\
4 \\
\end{array}$ & $1 \%$ & $\begin{array}{l}8 \cdot 30-4 \\
7 \cdot 27-4 \\
6.38-4 \\
\end{array}$ & $\begin{array}{l}8.29-4 \\
7.27-4 \\
6.37-4 \\
\end{array}$ & $\begin{array}{l}8 \cdot 28-4 \\
7 \cdot 26-4 \\
6 \cdot 37-4\end{array}$ & $\begin{array}{l}8 \cdot 27-4 \\
7.25-4 \\
6.35-4\end{array}$ & $\begin{array}{l}8.23-4 \\
7.22-4 \\
6.33-4\end{array}$ & $\begin{array}{l}8 \cdot 17-4 \\
7 \cdot 16-4 \\
6.28-4\end{array}$ \\
\hline $\begin{array}{l}2 \\
3 \\
4 \\
\end{array}$ & $10 \%$ & $\begin{array}{l}8.66-3 \\
7.59-3 \\
6.65-3 \\
\end{array}$ & $\begin{array}{l}8.61-3 \\
7.55-3 \\
6.62-3 \\
\end{array}$ & $\begin{array}{l}8.53-3 \\
7.48-3 \\
6.55-3 \\
\end{array}$ & $\begin{array}{l}8.36-3 \\
7.33-3 \\
6.43-3\end{array}$ & $\begin{array}{l}8.04-3 \\
7.05-3 \\
6.18-3\end{array}$ & $\begin{array}{l}7.45-3 \\
6.53-3 \\
5.73-3\end{array}$ \\
\hline $\begin{array}{r}2 \\
3 \\
4 \\
5 \\
10 \\
15 \\
20 \\
\end{array}$ & $20 \%$ & $\begin{array}{l}1.82-2 \\
1.60-2 \\
1.40-2 \\
1.23-2 \\
6.36-3 \\
3.29-3 \\
1.70-3\end{array}$ & $\begin{array}{l}1.81-2 \\
1.58-2 \\
1.39-2 \\
1.22-2 \\
6.30-3 \\
3.26-3 \\
1.69-3 \\
\end{array}$ & $\begin{array}{l}1.77-2 \\
1.55-2 \\
1.36-2 \\
1.19-2 \\
6.18-3 \\
3.20-3 \\
1.66-3 \\
\end{array}$ & $\begin{array}{l}1.71-2 \\
1.49-2 \\
1.31-2 \\
1.15-2 \\
5.95-3 \\
3.08-3 \\
1.59-3 \\
\end{array}$ & $\begin{array}{l}1.58-2 \\
1.39-2 \\
1.22-2 \\
1.07-2 \\
5.52-3 \\
2.86-3 \\
1.48-3\end{array}$ & $\begin{array}{l}1.37-2 \\
1.20-2 \\
1.05-2 \\
9.24-3 \\
4.78-3 \\
2.48-3 \\
1.28-3\end{array}$ \\
\hline $\begin{array}{r}2 \\
3 \\
4 \\
5 \\
10 \\
15 \\
20 \\
\end{array}$ & $40 \%$ & $\begin{array}{l}4.13-2 \\
3.62-2 \\
3.18-2 \\
2.78-2 \\
1.44-2 \\
7.46-3 \\
3.86-3 \\
\end{array}$ & $\begin{array}{l}4.06-2 \\
3.56-2 \\
3.12-2 \\
2.73-2 \\
1.41-2 \\
7.32-3 \\
3.79-3 \\
\end{array}$ & $\begin{array}{l}3.91-2 \\
3.43-2 \\
3.01-2 \\
2.64-2 \\
1.36-2 \\
7.06-3 \\
3.66-3\end{array}$ & $\begin{array}{l}3.65-2 \\
3.20-2 \\
2.80-2 \\
2.46-2 \\
1.27-2 \\
6.58-3 \\
3.41-3\end{array}$ & $\begin{array}{l}3.18-2 \\
2.79-2 \\
2.45-2 \\
2.15-2 \\
1.11-2 \\
5.75-3 \\
2.98-3\end{array}$ & $\begin{array}{l}2.49-2 \\
2.18-2 \\
1.91-2 \\
1.68-2 \\
8.68-3 \\
4.49-3 \\
2.33-3\end{array}$ \\
\hline $\begin{array}{r}2 \\
3 \\
4 \\
5 \\
10 \\
15 \\
20 \\
\end{array}$ & $60 \%$ & $\begin{array}{l}7.34-2 \\
6.44-2 \\
5.64-2 \\
4.95-2 \\
2.56-2 \\
1.33-2 \\
6.86-3 \\
\end{array}$ & $\begin{array}{l}7.16-2 \\
6.27-2 \\
5.50-2 \\
4.82-2 \\
2.50-2 \\
1.29-2 \\
6.69-3 \\
\end{array}$ & $\begin{array}{l}6.81-2 \\
5.97-2 \\
5.23-2 \\
4.59-2 \\
2.37-2 \\
1.23-2 \\
6.36-3 \\
\end{array}$ & $\begin{array}{l}6.19-2 \\
5.42-2 \\
4.75-2 \\
4.17-2 \\
2.16-2 \\
1.12-2 \\
5.78-3 \\
\end{array}$ & $\begin{array}{l}5.18-2 \\
4.54-2 \\
3.98-2 \\
3.49-2 \\
1.81-2 \\
9.34-3 \\
4.84-3 \\
\end{array}$ & $\begin{array}{l}3.81-2 \\
3.34-2 \\
2.92-2 \\
2.56-2 \\
1.33-2 \\
6.87-3 \\
3.56-3\end{array}$ \\
\hline $\begin{array}{r}2 \\
3 \\
4 \\
5 \\
10 \\
15 \\
20\end{array}$ & $80 \%$ & $\begin{array}{l}1.28-1 \\
1.12-1 \\
9 \cdot 81-2 \\
8 \cdot 60-2 \\
4.45-2 \\
2.30-2 \\
1.19-2\end{array}$ & $\begin{array}{l}1.24-1 \\
1.09-1 \\
9 \cdot 52-2 \\
8 \cdot 35-2 \\
4.32-2 \\
2.24-2 \\
1.16-2\end{array}$ & $\begin{array}{l}1.17-1 \\
1.03-1 \\
8.99-2 \\
7.88-2 \\
4.08-2 \\
2.11-2 \\
1.09-2\end{array}$ & $\begin{array}{l}1.05-1 \\
9.21-2 \\
8.07-2 \\
7.07-2 \\
3.66-2 \\
1.90-2 \\
9.81-3\end{array}$ & $\begin{array}{l}8.64-2 \\
7.57-2 \\
6.64-2 \\
5.82-2 \\
3.01-2 \\
1.56-2 \\
8.07-3\end{array}$ & $\begin{array}{l}6.28-2 \\
5.51-2 \\
4.83-2 \\
4.23-2 \\
2.19-2 \\
1.13-2 \\
5.87-3\end{array}$ \\
\hline
\end{tabular}


Table B8. Photon Dose Rates in Air, rem/h per $g^{235} U$ Burned (ORIGEN: All Fission Products - MCNP)

(Fuel-Assembly Model Dose Rates)

\begin{tabular}{|c|c|c|c|c|c|c|c|}
\hline \multirow{2}{*}{\multicolumn{2}{|c|}{$\begin{array}{l}\text { Decay } \\
\text { Time, y } \\
\text { Burnup, } \\
{ }^{2}{ }^{235} U\end{array}$}} & \multicolumn{6}{|c|}{ Assembly Power Density, $\mathrm{MW} / \mathrm{kg}^{235} \mathrm{U}$} \\
\hline & & 2.857 & 1.429 & 0.714 & 0.357 & 0.179 & 0.089 \\
\hline $\begin{array}{l}2 \\
3 \\
4\end{array}$ & $1 \%$ & $\begin{array}{l}2.17+0 \\
1.33+0 \\
1.06+0\end{array}$ & $\begin{array}{l}2.16+0 \\
1.33+0 \\
1.06+0\end{array}$ & $\begin{array}{l}2.15+0 \\
1.33+0 \\
1.06+0\end{array}$ & $\begin{array}{l}2.12+0 \\
1.33+0 \\
1.06+0\end{array}$ & $\begin{array}{l}2.08+0 \\
1.31+0 \\
1.06+0\end{array}$ & $\begin{array}{l}2.00+0 \\
1.31+0 \\
1.05+0\end{array}$ \\
\hline $\begin{array}{l}2 \\
3 \\
4 \\
\end{array}$ & $10 \%$ & $\begin{array}{l}2.22+0 \\
1.40+0 \\
1.12+0\end{array}$ & $\begin{array}{l}2.20+0 \\
1.41+0 \\
1.13+0 \\
\end{array}$ & $\begin{array}{l}2 \cdot 12+0 \\
1 \cdot 41+0 \\
1.13+0\end{array}$ & $\begin{array}{l}1.93+0 \\
1.36+0 \\
1.11+0\end{array}$ & $\begin{array}{l}1.76+0 \\
1.28+0 \\
1.07+0\end{array}$ & $\begin{array}{l}1.50+0 \\
1.17+0 \\
1.01+0\end{array}$ \\
\hline $\begin{array}{r}2 \\
3 \\
4 \\
5 \\
10 \\
15 \\
20 \\
\end{array}$ & $20 \%$ & $\begin{array}{l}2.37+0 \\
1.54+0 \\
1.22+0 \\
1.06+0 \\
7.85-1 \\
6.80-1 \\
6.00-1\end{array}$ & $\begin{array}{l}2.34+0 \\
1.56+0 \\
1.24+0 \\
1.07+0 \\
7.85-1 \\
6.80-1 \\
6.00-1 \\
\end{array}$ & $\begin{array}{l}2.19+0 \\
1.51+0 \\
1.23+0 \\
1.07+0 \\
7.85-1 \\
6.75-1 \\
6.00-1 \\
\end{array}$ & $\begin{array}{l}1.95+0 \\
1.43+0 \\
1.18+0 \\
1.04+0 \\
7.75-1 \\
6.70-1 \\
5.95-1 \\
\end{array}$ & $\begin{array}{l}1 \cdot 68+0 \\
1.30+0 \\
1.11+0 \\
9 \cdot 95-1 \\
7.65-1 \\
6.60-1 \\
5.85-1\end{array}$ & $\begin{array}{l}1.40+0 \\
1.15+0 \\
1.02+0 \\
9.35-1 \\
7.35-1 \\
6.40-1 \\
5.70-1\end{array}$ \\
\hline $\begin{array}{r}2 \\
3 \\
4 \\
5 \\
10 \\
15 \\
20 \\
\end{array}$ & $40 \%$ & $\begin{array}{l}2.83+0 \\
1.91+0 \\
1.50+0 \\
1.26+0 \\
8.28-1 \\
6.90-1 \\
6.05-1\end{array}$ & $\begin{array}{l}2.70+0 \\
1.89+0 \\
1.49+0 \\
1.26+0 \\
8.28-1 \\
6.88-1 \\
6.03-1\end{array}$ & $\begin{array}{l}2.46+0 \\
1.80+0 \\
1.44+0 \\
1.23+0 \\
8.18-1 \\
6.83-1 \\
5.98-1\end{array}$ & $\begin{array}{l}2.14+0 \\
1.63+0 \\
1.34+0 \\
1.17+0 \\
8.00-1 \\
6.70-1 \\
5.90-1\end{array}$ & $\begin{array}{l}1.79+0 \\
1.43+0 \\
1.21+0 \\
1.08+0 \\
7.70-1 \\
6.50-1 \\
5.73-1\end{array}$ & $\begin{array}{l}1.42+0 \\
1.20+0 \\
1.06+0 \\
9.55-1 \\
7.18-1 \\
6.15-1 \\
5.40-1\end{array}$ \\
\hline $\begin{array}{r}2 \\
3 \\
4 \\
5 \\
10 \\
15 \\
20 \\
\end{array}$ & $60 \%$ & $\begin{array}{l}3.47+0 \\
2.42+0 \\
1.87+0 \\
1.53+0 \\
8.88-1 \\
7.02-1 \\
6.08-1 \\
\end{array}$ & $\begin{array}{l}3.28+0 \\
2.35+0 \\
1.83+0 \\
1.51+0 \\
8.83-1 \\
7.02-1 \\
6.08-1 \\
\end{array}$ & $\begin{array}{l}2.97+0 \\
2.20+0 \\
1.75+0 \\
1.46+0 \\
8.67-1 \\
6.92-1 \\
6.03-1 \\
\end{array}$ & $\begin{array}{l}2 \cdot 53+0 \\
1.95+0 \\
1.59+0 \\
1.35+0 \\
8.32-1 \\
6.73-1 \\
5.87-1\end{array}$ & $\begin{array}{l}2.05+0 \\
1.65+0 \\
1.38+0 \\
1.20+0 \\
7.88-1 \\
6.47-1 \\
5.60-1\end{array}$ & $\begin{array}{l}1.58+0 \\
1.31+0 \\
1.13+0 \\
1.00+0 \\
7.08-1 \\
5.93-1 \\
5.17-1\end{array}$ \\
\hline $\begin{array}{r}2 \\
3 \\
4 \\
5 \\
10 \\
15 \\
20 \\
\end{array}$ & $80 \%$ & $\begin{array}{l}4.53+0 \\
3 \cdot 21+0 \\
2.45+0 \\
1.95+0 \\
9.74-1 \\
7.28-1 \\
6.20-1 \\
\end{array}$ & $\begin{array}{l}4 \cdot 26+0 \\
3 \cdot 10+0 \\
2 \cdot 39+0 \\
1 \cdot 91+0 \\
9 \cdot 66-1 \\
7 \cdot 24-1 \\
6.11-1 \\
\end{array}$ & $\begin{array}{l}3.84+0 \\
2.86+0 \\
2.24+0 \\
1.81+0 \\
9.41-1 \\
7.11-1 \\
6.04-1\end{array}$ & $\begin{array}{l}3.25+0 \\
2.49+0 \\
1.99+0 \\
1.64+0 \\
8.93-1 \\
6.85-1 \\
5.85-1 \\
\end{array}$ & $\begin{array}{l}2.60+0 \\
2.05+0 \\
1.66+0 \\
1.40+0 \\
8.20-1 \\
6.40-1 \\
5.49-1 \\
\end{array}$ & $\begin{array}{l}1.93+0 \\
1.56+0 \\
1.31+0 \\
1.13+0 \\
7.10-1 \\
5.73-1 \\
4.94-1\end{array}$ \\
\hline
\end{tabular}


Table B9. Photon Dose Rates in Air, rem/h per $9^{235} \mathrm{U}$ Burned (ORIGEN: All Fission Products - MCNP) (Revised Fuel-Assembly Model Dose Rates)

\begin{tabular}{|c|c|c|c|c|c|c|c|}
\hline \multirow{2}{*}{\multicolumn{2}{|c|}{$\begin{array}{l}\text { Decay } \\
\text { Time, y } \\
\text { Burnup, } \\
\%^{235} \mathrm{U}\end{array}$}} & \multicolumn{6}{|c|}{ Assembly Power Density, $\mathrm{MW} / \mathrm{kg}^{235} \mathrm{U}$} \\
\hline & & 2.857 & 1.429 & 0.714 & 0.357 & 0.179 & 0.089 \\
\hline $\begin{array}{l}2 \\
3 \\
4 \\
\end{array}$ & $1 \%$ & $\begin{array}{l}1.84+0 \\
1.13+0 \\
9.01-1\end{array}$ & $\begin{array}{l}1.84+0 \\
1.13+0 \\
9.01-1\end{array}$ & $\begin{array}{l}1.83+0 \\
1.13+0 \\
9.01-1\end{array}$ & $\begin{array}{l}1.80+0 \\
1.13+0 \\
9.01-1\end{array}$ & $\begin{array}{l}1.77+0 \\
1.11+0 \\
9.01-1\end{array}$ & $\begin{array}{l}1 \cdot 70+0 \\
1.11+0 \\
8 \cdot 92-1\end{array}$ \\
\hline $\begin{array}{l}2 \\
3 \\
4 \\
\end{array}$ & $10 \%$ & $\begin{array}{l}1 \cdot 89+0 \\
1 \cdot 19+0 \\
9 \cdot 52-1\end{array}$ & $\begin{array}{l}1.87+0 \\
1.20+0 \\
9.61-1\end{array}$ & $\begin{array}{l}1.80+0 \\
1.20+0 \\
9.61-1\end{array}$ & $\begin{array}{l}1.64+0 \\
1.16+0 \\
9.44-1\end{array}$ & $\begin{array}{l}1.50+0 \\
1.09+0 \\
9.10-1\end{array}$ & $\begin{array}{l}1.28+0 \\
9 \cdot 95-1 \\
8 \cdot 59-1\end{array}$ \\
\hline $\begin{array}{r}2 \\
3 \\
4 \\
5 \\
10 \\
15 \\
20 \\
\end{array}$ & $20 \%$ & $\begin{array}{l}2.01+0 \\
1.31+0 \\
1.04+0 \\
8.97-1 \\
6.67-1 \\
5.78-1 \\
5.10-1 \\
\end{array}$ & $\begin{array}{l}1.98+0 \\
1.32+0 \\
1.05+0 \\
9 \cdot 10-1 \\
6.67-1 \\
5.78-1 \\
5.10-1 \\
\end{array}$ & $\begin{array}{l}1.86+0 \\
1.28+0 \\
1.04+0 \\
9.05-1 \\
6.67-1 \\
5.74-1 \\
5.10-1\end{array}$ & $\begin{array}{l}1.66+0 \\
1.21+0 \\
9.99-1 \\
8.80-1 \\
6.59-1 \\
5.70-1 \\
5.06-1 \\
\end{array}$ & $\begin{array}{l}1.42+0 \\
1.11+0 \\
9.44-1 \\
8.46-1 \\
6.50-1 \\
5.61-1 \\
4.97-1\end{array}$ & $\begin{array}{l}1.19+0 \\
9.78-1 \\
8.63-1 \\
7.95-1 \\
6.25-1 \\
5.44-1 \\
4.85-1\end{array}$ \\
\hline $\begin{array}{r}2 \\
3 \\
4 \\
5 \\
10 \\
15 \\
20\end{array}$ & $40 \%$ & $\begin{array}{l}2.40+0 \\
1.62+0 \\
1.27+0 \\
1.07+0 \\
7.03-1 \\
5.87-1 \\
5.14-1 \\
\end{array}$ & $\begin{array}{l}2.30+0 \\
1.60+0 \\
1.27+0 \\
1.07+0 \\
7.03-1 \\
5.84-1 \\
5.12-1 \\
\end{array}$ & $\begin{array}{l}2.09+0 \\
1.53+0 \\
1.22+0 \\
1.04+0 \\
6.95-1 \\
5.80-1 \\
5.08-1\end{array}$ & $\begin{array}{l}1.82+0 \\
1.39+0 \\
1.14+0 \\
9.90-1 \\
6.80-1 \\
5.70-1 \\
5.02-1\end{array}$ & $\begin{array}{l}1 \cdot 52+0 \\
1.22+0 \\
1.03+0 \\
9 \cdot 20-1 \\
6.55-1 \\
5 \cdot 53-1 \\
4 \cdot 87-1\end{array}$ & $\begin{array}{l}1.21+0 \\
1.02+0 \\
8.99-1 \\
8.12-1 \\
6.10-1 \\
5.23-1 \\
4.59-1\end{array}$ \\
\hline $\begin{array}{r}2 \\
3 \\
4 \\
5 \\
10 \\
15 \\
20 \\
\end{array}$ & $60 \%$ & $\begin{array}{l}2.95+0 \\
2.05+0 \\
1.59+0 \\
1.30+0 \\
7.55-1 \\
5.96-1 \\
5.17-1 \\
\end{array}$ & $\begin{array}{l}2.79+0 \\
2.00+0 \\
1.56+0 \\
1.29+0 \\
7.51-1 \\
5.96-1 \\
5.17-1 \\
\end{array}$ & $\begin{array}{l}2.52+0 \\
1.87+0 \\
1.49+0 \\
1.24+0 \\
7.37-1 \\
5.88-1 \\
5.13-1 \\
\end{array}$ & $\begin{array}{l}2.15+0 \\
1.66+0 \\
1.35+0 \\
1.15+0 \\
7.07-1 \\
5.72-1 \\
4.99-1 \\
\end{array}$ & $\begin{array}{l}1.74+0 \\
1.40+0 \\
1.17+0 \\
1.02+0 \\
6.70-1 \\
5.50-1 \\
4.76-1 \\
\end{array}$ & $\begin{array}{l}1.34+0 \\
1.12+0 \\
9.63-1 \\
8.54-1 \\
6.02-1 \\
5.04-1 \\
4.39-1\end{array}$ \\
\hline $\begin{array}{r}2 \\
3 \\
4 \\
5 \\
10 \\
15 \\
20\end{array}$ & $80 \%$ & $\begin{array}{l}3.85+0 \\
2.73+0 \\
2.08+0 \\
1.66+0 \\
8.28-1 \\
6.18-1 \\
5.27-1\end{array}$ & $\begin{array}{l}3.62+0 \\
2.64+0 \\
2.03+0 \\
1.63+0 \\
8.21-1 \\
6.15-1 \\
5.20-1\end{array}$ & $\begin{array}{l}3.26+0 \\
2.43+0 \\
1.90+0 \\
1.54+0 \\
8.00-1 \\
6.05-1 \\
5.13-1\end{array}$ & $\begin{array}{l}2.76+0 \\
2.11+0 \\
1.69+0 \\
1.39+0 \\
7.59-1 \\
5.82-1 \\
4.97-1\end{array}$ & $\begin{array}{l}2.21+0 \\
1.74+0 \\
1.41+0 \\
1.19+0 \\
6.97-1 \\
5.44-1 \\
4.66-1\end{array}$ & $\begin{array}{l}1.64+0 \\
1.33+0 \\
1.12+0 \\
9.57-1 \\
6.04-1 \\
4.87-1 \\
4.20-1\end{array}$ \\
\hline
\end{tabular}


Table B10. Self-Protecting U-235 Mass, $\mathrm{g}^{23.5} \mathrm{U}$ Burned per $100 \mathrm{rem} / \mathrm{h}$ (ORIGEN: All Fission Products - MCNP)

(Revised Fuel-Assembly Model Dose Rates)

\begin{tabular}{|c|c|c|c|c|c|c|c|}
\hline \multirow{2}{*}{\multicolumn{2}{|c|}{$\begin{array}{l}\text { Decay } \\
\text { Time, y } \\
\text { Burnup, } \\
\frac{\circ}{6}{ }^{235} U\end{array}$}} & \multicolumn{6}{|c|}{ Assembly Power Density, $\mathrm{MW} / \mathrm{kg}^{235} \mathrm{U}$} \\
\hline & & 2.857 & 1.429 & 0.714 & 0.357 & 0.179 & 0.089 \\
\hline $\begin{array}{l}2 \\
3 \\
4 \\
\end{array}$ & $1 \%$ & $\begin{array}{r}54.2 \\
88.5 \\
111.0 \\
\end{array}$ & $\begin{array}{r}54.5 \\
88.5 \\
111.0 \\
\end{array}$ & $\begin{array}{r}54.7 \\
88.5 \\
111.0 \\
\end{array}$ & $\begin{array}{r}55.5 \\
88.5 \\
111.0 \\
\end{array}$ & $\begin{array}{r}56.6 \\
89.8 \\
111.0 \\
\end{array}$ & $\begin{array}{r}58.8 \\
89.8 \\
112.0 \\
\end{array}$ \\
\hline $\begin{array}{l}2 \\
3 \\
4 \\
\end{array}$ & $10 \%$ & $\begin{array}{r}53.0 \\
84.0 \\
105.0 \\
\end{array}$ & $\begin{array}{r}53.5 \\
83.4 \\
104.1 \\
\end{array}$ & $\begin{array}{r}55.5 \\
83.4 \\
104.1 \\
\end{array}$ & $\begin{array}{r}61.0 \\
86.5 \\
106.0 \\
\end{array}$ & $\begin{array}{r}66.8 \\
91.9 \\
110.0 \\
\end{array}$ & $\begin{array}{r}78.4 \\
100.6 \\
116.5 \\
\end{array}$ \\
\hline $\begin{array}{r}2 \\
3 \\
4 \\
5 \\
10 \\
15 \\
20\end{array}$ & $20 \%$ & $\begin{array}{r}49.6 \\
76.4 \\
96.4 \\
111.5 \\
149.9 \\
173.0 \\
196.1 \\
\end{array}$ & $\begin{array}{r}50.4 \\
75.7 \\
95.3 \\
110.0 \\
149.9 \\
173.0 \\
196.1\end{array}$ & $\begin{array}{r}53.7 \\
77.9 \\
96.0 \\
110.5 \\
149.9 \\
174.3 \\
196.1 \\
\end{array}$ & $\begin{array}{r}60.3 \\
82.6 \\
100.1 \\
113.7 \\
151.8 \\
175.6 \\
197.7 \\
\end{array}$ & $\begin{array}{r}70.2 \\
90.5 \\
106.0 \\
118.2 \\
153.8 \\
178.3 \\
201.1\end{array}$ & $\begin{array}{r}84.0 \\
102.3 \\
115.9 \\
125.8 \\
160.1 \\
183.8 \\
206.4\end{array}$ \\
\hline $\begin{array}{r}2 \\
3 \\
4 \\
5 \\
10 \\
15 \\
20 \\
\end{array}$ & $40 \%$ & $\begin{array}{r}41.6 \\
61.6 \\
78.6 \\
93.6 \\
142.2 \\
170.5 \\
194.5 \\
\end{array}$ & $\begin{array}{r}43.6 \\
62.4 \\
79.0 \\
93.7 \\
142.2 \\
171.1 \\
195.3 \\
\end{array}$ & $\begin{array}{r}47.8 \\
65.5 \\
81.8 \\
95.8 \\
143.9 \\
172.4 \\
196.9 \\
\end{array}$ & $\begin{array}{r}54.9 \\
72.1 \\
87.6 \\
101.0 \\
147.1 \\
175.6 \\
199.4 \\
\end{array}$ & $\begin{array}{r}65.8 \\
82.1 \\
97.0 \\
108.7 \\
152.8 \\
181.0 \\
205.5 \\
\end{array}$ & $\begin{array}{r}82.7 \\
98.0 \\
111.3 \\
123.2 \\
164.0 \\
191.3 \\
217.9 \\
\end{array}$ \\
\hline $\begin{array}{r}2 \\
3 \\
4 \\
5 \\
10 \\
15 \\
20 \\
\end{array}$ & $60 \%$ & $\begin{array}{r}33.9 \\
48.7 \\
63.0 \\
76.8 \\
132.4 \\
167.7 \\
193.4 \\
\end{array}$ & $\begin{array}{r}35.8 \\
50.1 \\
64.2 \\
77.7 \\
133.2 \\
167.7 \\
193.4 \\
\end{array}$ & $\begin{array}{r}39.7 \\
53.5 \\
67.2 \\
80.8 \\
135.7 \\
170.1 \\
195.0 \\
\end{array}$ & $\begin{array}{r}46.4 \\
60.3 \\
74.1 \\
87.3 \\
141.5 \\
174.7 \\
200.5 \\
\end{array}$ & $\begin{array}{r}57.4 \\
71.5 \\
85.3 \\
98.0 \\
149.2 \\
181.9 \\
210.1 \\
\end{array}$ & $\begin{array}{r}74.5 \\
89.6 \\
103.8 \\
117.1 \\
166.1 \\
198.3 \\
227.7 \\
\end{array}$ \\
\hline $\begin{array}{r}2 \\
3 \\
4 \\
5 \\
10 \\
15 \\
20\end{array}$ & $80 \%$ & $\begin{array}{r}26.0 \\
36.6 \\
48.0 \\
60.3 \\
120.8 \\
161.7 \\
189.8\end{array}$ & $\begin{array}{r}27.6 \\
38.0 \\
49.3 \\
61.5 \\
121.8 \\
162.6 \\
192.5\end{array}$ & $\begin{array}{r}30.7 \\
41.1 \\
52.6 \\
64.9 \\
125.0 \\
165.4 \\
194.9\end{array}$ & $\begin{array}{r}36.2 \\
47.3 \\
59.2 \\
71.8 \\
131.8 \\
171.7 \\
201.1\end{array}$ & $\begin{array}{r}45.2 \\
57.4 \\
70.8 \\
84.0 \\
143.5 \\
183.8 \\
214.4\end{array}$ & $\begin{array}{r}61.1 \\
75.3 \\
89.6 \\
104.5 \\
165.7 \\
205.5 \\
238.3\end{array}$ \\
\hline
\end{tabular}


Table B11. Self-Protecting U-235 Mass, $\mathrm{g}^{235} \mathrm{U}$ Burned per $100 \mathrm{rem} / \mathrm{h}$ (FP's: ${ }^{90} \mathrm{Sr}{ }^{40} \mathrm{Y}{ }^{95} \mathrm{Zr}{ }^{45} \mathrm{Nb}{ }^{106} \mathrm{Rh}{ }^{134} \mathrm{Cs}{ }^{137} \mathrm{Cs} \quad{ }^{137 \mathrm{~m}} \mathrm{Ba}{ }^{144} \mathrm{Ce}{ }^{144} \mathrm{Pr}$ )

(Equivalent Fuel-Assembly Model Dose Rates)

\begin{tabular}{|c|c|c|c|c|c|c|c|}
\hline \multirow{2}{*}{\multicolumn{2}{|c|}{$\begin{array}{l}\text { Decay } \\
\text { Time, y } \\
\text { Burnup, } \\
\%^{235} \mathrm{U}\end{array}$}} & \multicolumn{6}{|c|}{ Assembly Power Density, $\mathrm{MW} / \mathrm{kg}^{235} \mathrm{U}$} \\
\hline & & 2.857 & 1.429 & 0.714 & 0.357 & 0.179 & 0.089 \\
\hline $\begin{array}{l}2 \\
3 \\
4 \\
\end{array}$ & $1 \%$ & $\begin{array}{r}52.9 \\
85.3 \\
106.0\end{array}$ & $\begin{array}{r}53.1 \\
85.3 \\
106.1 \\
\end{array}$ & $\begin{array}{r}53.4 \\
85.5 \\
106.2\end{array}$ & $\begin{array}{r}54.1 \\
85.9 \\
106.5\end{array}$ & $\begin{array}{r}55.3 \\
86.6 \\
107.0\end{array}$ & $\begin{array}{r}57.7 \\
88.1 \\
108.0\end{array}$ \\
\hline $\begin{array}{l}2 \\
3 \\
4 \\
\end{array}$ & $10 \%$ & $\begin{array}{l}50.2 \\
78.7 \\
98.5 \\
\end{array}$ & $\begin{array}{l}51.6 \\
79.5 \\
99.1 \\
\end{array}$ & $\begin{array}{r}54.1 \\
81.1 \\
100.2 \\
\end{array}$ & $\begin{array}{r}58.5 \\
34.1 \\
102.4\end{array}$ & $\begin{array}{r}65.7 \\
89.4 \\
106.2\end{array}$ & $\begin{array}{r}76.7 \\
97.8 \\
112.2 \\
\end{array}$ \\
\hline $\begin{array}{r}2 \\
3 \\
4 \\
5 \\
10 \\
15 \\
20 \\
\end{array}$ & $20 \%$ & $\begin{array}{r}47.1 \\
71.9 \\
90.5 \\
105.0 \\
142.6 \\
164.8 \\
186.1 \\
\end{array}$ & $\begin{array}{r}49.2 \\
73.3 \\
91.6 \\
105.8 \\
143.0 \\
165.2 \\
186.4 \\
\end{array}$ & $\begin{array}{r}53.0 \\
76.0 \\
93.6 \\
107.3 \\
143.6 \\
165.8 \\
187.1 \\
\end{array}$ & $\begin{array}{r}59.2 \\
80.7 \\
97.3 \\
110.1 \\
145.0 \\
167.0 \\
188.4 \\
\end{array}$ & $\begin{array}{r}68.9 \\
88.5 \\
103.4 \\
114.8 \\
147.5 \\
169.5 \\
191.1 \\
\end{array}$ & $\begin{array}{r}82.7 \\
99.8 \\
112.4 \\
122.2 \\
152.5 \\
174.5 \\
196.6 \\
\end{array}$ \\
\hline $\begin{array}{r}2 \\
3 \\
4 \\
5 \\
10 \\
15 \\
20 \\
\end{array}$ & $40 \%$ & $\begin{array}{r}40.3 \\
59.4 \\
75.7 \\
90.2 \\
137.0 \\
163.6 \\
186.1 \\
\end{array}$ & $\begin{array}{r}43.1 \\
61.5 \\
77.5 \\
91.7 \\
137.8 \\
164.3 \\
186.8 \\
\end{array}$ & $\begin{array}{r}47.6 \\
65.3 \\
80.8 \\
94.5 \\
139.3 \\
165.6 \\
188.1 \\
\end{array}$ & $\begin{array}{r}54.9 \\
71.8 \\
86.5 \\
99.4 \\
142.3 \\
168.2 \\
190.8 \\
\end{array}$ & $\begin{array}{r}66.1 \\
82.0 \\
95.7 \\
107.7 \\
147.8 \\
173.3 \\
196.3 \\
\end{array}$ & $\begin{array}{r}82.2 \\
97.2 \\
110.0 \\
120.9 \\
158.3 \\
183.7 \\
207.6 \\
\end{array}$ \\
\hline $\begin{array}{r}2 \\
3 \\
4 \\
5 \\
10 \\
15 \\
20\end{array}$ & $60 \%$ & $\begin{array}{r}33.4 \\
48.0 \\
62.1 \\
75.9 \\
130.2 \\
162.0 \\
185.9\end{array}$ & $\begin{array}{r}36.0 \\
50.3 \\
64.2 \\
77.9 \\
131.4 \\
163.0 \\
187.0\end{array}$ & $\begin{array}{r}40.3 \\
54.4 \\
68.2 \\
81.6 \\
134.0 \\
165.0 \\
189.0\end{array}$ & $\begin{array}{r}47.4 \\
61.3 \\
75.0 \\
88.1 \\
138.7 \\
169.0 \\
193.2\end{array}$ & $\begin{array}{r}58.5 \\
72.7 \\
86.3 \\
99.2 \\
147.4 \\
177.0 \\
201.6\end{array}$ & $\begin{array}{r}76.0 \\
90.9 \\
104.7 \\
117.4 \\
163.5 \\
192.9 \\
218.9\end{array}$ \\
\hline $\begin{array}{r}2 \\
3 \\
4 \\
5 \\
10 \\
15 \\
20\end{array}$ & $80 \%$ & $\begin{array}{r}26.5 \\
37.6 \\
49.3 \\
61.7 \\
121.4 \\
159.5 \\
185.6\end{array}$ & $\begin{array}{r}28.7 \\
39.6 \\
51.4 \\
63.9 \\
123.2 \\
160.9 \\
187.0\end{array}$ & $\begin{array}{r}32.2 \\
43.3 \\
55.3 \\
67.9 \\
126.6 \\
163.8 \\
189.8\end{array}$ & $\begin{array}{r}38.2 \\
49.8 \\
62.2 \\
75.1 \\
133.1 \\
169.3 \\
195.4\end{array}$ & $\begin{array}{r}48.1 \\
60.8 \\
74.1 \\
87.6 \\
144.9 \\
180.1 \\
206.7\end{array}$ & $\begin{array}{r}65.0 \\
79.6 \\
94.4 \\
108.9 \\
166.5 \\
201.9 \\
230.4\end{array}$ \\
\hline
\end{tabular}




\section{PHDOSE Program}

PURPOSE To calculate the photon dose rate from spent fuel.

INPUT (format 7D10.5)

ti Irradiation time (d)

- if $t i=0.0, t i$ is calculated from the powden and burnup parameters as: $t i=$ burnup/powden*8, assuming $1.25 \mathrm{~g}^{235} \mathrm{U}$ burned per MWd.

- if $t i \geq 0.0$, normal output is printed.

- if $t i<0.0, t i=-t i$ and optional output is also printed.

- note: if $t i \neq 0.0$, ti must be within $1 \%$ of the calculated irradiation time. ( $\geq 1 \%$, stop code 101)

power Assembly power (MW)

powden Assembly power density (MW/ $\mathrm{kg}^{235} \mathrm{U}$ )

td

$\mathrm{kg}$ Fission product decay time $(Y)$

ppm

burnup Structural material mass $(\mathrm{kg})$

${ }^{59} \mathrm{Co}$ in structural material (ppm)

${ }^{235} \mathrm{U}$ burnup in fuel (\%)

NORMAL OUTPUTT

Record \#1:

- Echo input (ti, power, powden, td, kg, ppm, burnup)

- Average neutron flux (n/ $\left.\mathrm{cm}^{2}-s\right)$

Record \#2:

- ${ }^{235} U$ burned (g) [= power/powden*burnup*10]

- Fission product photon source rate (ph/s) per $\mathrm{g}^{235} \mathrm{U}$ burned

- ${ }^{60}$ Co photon source rate (ph/s)

- Self-protecting ${ }^{235} \mathrm{U}$ mass, ( ${ }^{235} \mathrm{U}$ burned)

- Fission product photon dose rate (rem/h) per $g^{235} U$ burned

- ${ }^{60}$ Co photon dose rate (rem/h)

Fission products (FP):

${ }^{90} \mathrm{Sr},{ }^{90} \mathrm{Y},{ }^{134} \mathrm{Cs},{ }^{137} \mathrm{Cs},{ }^{137 \mathrm{~m}} \mathrm{Ba},{ }^{144} \mathrm{Ce},{ }^{144} \mathrm{Pr},{ }^{106} \mathrm{Rh},{ }^{95} \mathrm{Zr},{ }^{95} \mathrm{Nb}$

OPTIONAL OUTPUT

-Isotope formation rates (atoms/s)

- Isotope loss rates (atoms/s)

-Isotope atoms present at time ti (atoms)

-Isotope atoms present at time td (atoms)

-Energy dependent, isotope photon source rates (ph/s)

-Energy dependent, FP and ${ }^{60} \mathrm{Co}$ photon fluxes (ph/ $\mathrm{cm}^{2}-\mathrm{s}$ )

-Energy dependent, isotope photon dose rates (rem/h)

Isotope order: ${ }^{90} \mathrm{Sr},{ }^{901} \mathrm{Y},{ }^{133} \mathrm{Cs},{ }^{134} \mathrm{Cs},{ }^{137} \mathrm{Cs},{ }^{137 \mathrm{~m}} \mathrm{Ba},{ }^{146} \mathrm{Ce},{ }^{144} \mathrm{Pr},{ }^{106} \mathrm{Ru}$,

Energy order: $0.30,0.63$ and $1.10 \mathrm{MeV}$ 
program phdose

c hand calculation of photon dose rate

real*8 dk(13), yield(13), cap (13), r(13), $k(13), n 0(13), n(13), f 2 d(3)$

real*8 gsour (5), gflux(5), gdose (5), ph(20), srate (20), drate (20)

real*8 $t i$, power, powden, $t d, k g, p p m$, burnup

real* 8 bu, time, dm, pflux, nflux, sums, sumd, self

common dk, cap, $r$, no, powden, $\mathrm{kg}, \mathrm{ppm}$, bu, time

c parameter order in data arrays:

$\begin{array}{llllll}\mathrm{c} & \text { material } & \mathrm{t}(1 / 2) & \mathrm{ph} / \mathrm{dis} & \text { groups* } \\ \mathrm{c} & \# 01 \mathrm{Sr}-90 & 28.1 \mathrm{y} & \# 01-\# 02 & \# 1-\# 2 \\ \mathrm{c} & \# 02 \mathrm{y}-90 & 2.67 \mathrm{~d} & \# 03-\# 05 & \# 1-\# 3 \\ \mathrm{c} & \# 03 \mathrm{Cs}-133 & & & \\ \mathrm{c} & \# 04 \mathrm{Cs}-134 & 2.06 \mathrm{y} & \# 06-\# 07 & \# 2-\# 3 \\ \mathrm{c} & \# 05 \mathrm{Cs}-137 & 30.1 \mathrm{y} & \# 08-\# 09 & \# 1-\# 2 \\ \mathrm{c} & \# 06 \mathrm{Ba}-137 \mathrm{~m} & 2.55 \mathrm{~m} & \# 10 & \# 2 \\ \mathrm{c} & \# 07 \mathrm{Ce}-144 & 284 . \mathrm{d} & \# 11 & \# 1 \\ \mathrm{c} & \# 08 \mathrm{Pr}-144 & 17.3 \mathrm{~m} & \# 12-\# 14 & \# 1-\# 3 \\ \mathrm{c} & \# 09 \mathrm{Ru}-106 & 1.01 \mathrm{y} & & \\ \mathrm{c} & \# 10 \mathrm{Rh}-106 & 29.9 \mathrm{~s} & \# 15-\# 17 & \# 1-\# 3 \\ \mathrm{c} & \# 11 \mathrm{zr}-95 & 65.5 \mathrm{~d} & \# 18 & \# 2 \\ \mathrm{c} & \# 12 \mathrm{Nb}-95 & 35.1 \mathrm{~d} & \# 19 & \# 2 \\ \mathrm{c} & \# 13 \mathrm{Co}-60 & 5.26 \mathrm{y} & \# 20 & \# 5\end{array}$

c *gps, MeV: $\# 1=0.30, \# 2=0.63, \# 3=1.10, \# 4=$ sum $\# 1-\# 3, \# 5=C 0-60$ (1.10)

c decay constant, $s-1$

data $\mathrm{dk} / 7.816 \mathrm{~d}-10,3.005 \mathrm{~d}-6,0 . \mathrm{d0}, 1.066 \mathrm{~d}-8,7.297 \mathrm{~d}-10,4.530 \mathrm{~d}-3$,

$\times 2.821 d-8,6.684 d-4,2.174 d-8,2.318 d-2,1.225 d-7,2.285 d-7,4.176 d-9 /$

c fission product yield

data yield $/ 5.8 d-2,0 . d 0,6.69 d-2,0 . d 0,6.19 d-2,0 . d 0,5.5 d-2,0 . d 0$,

$x 4.01 d-3,0 . d 0,6.5 d-2,2 * 0 . d 0 /$

c capture cross section, $\mathrm{cm}^{* * 2}$

data cap/1.028d-24,2.740d-24,103.2d-24,107.1d-24,0.1310d-24,

$x 0 . d 0,1.172 d-24,0 . d 0,0.4550 d-24,2 * 0 . d 0,3.563 d-24,4.275 d-24 /$

c photons/disintegration

data $\mathrm{ph} / 4.69 \mathrm{~d}-3,4.39 \mathrm{~d}-6,4.94 \mathrm{~d}-2,1.62 \mathrm{~d}-2,2.48 \mathrm{~d}-3,2.4 \mathrm{do}, 3.1 \mathrm{~d}-2$,

$x 1.01 d-2,4.24 d-5,1.05 d 0,1.0 d-1,7.53 d-2,4.32 d-2,8.67 d-3,1.53 d-1$,

c photon flux

$x 3.43 \mathrm{~d}-1,5.2 \mathrm{~d}-2,1.15 \mathrm{do}, 1.22 \mathrm{do}, 2.28 \mathrm{do} /$

data pflux/7.692d-6/

c fluence-to-dose factor, sv-cm**2

data $f 2 d / 1.56 d-12,3.116 d-12,4.928 d-12 /$

c flux-to-dose conversion, rem/h

do $105 i=1,3$

$105 f 2 d(i)=f 2 d(i) * 3.6 d 5$

10 format (7d10.5)

11 format $(1 \mathrm{x}, 1 \mathrm{p} 6 \mathrm{~d} 12.5)$

c read input: irrad time (d); power (MW); pow den (MW/kgU-235);

c decay time $(y)$; asby mass $(\mathrm{kg})$; Co-59 (ppm); U-235 burnup (z)

$c$ note: if $t i=0, t i$ is calculated in the 'time' parameter below

$100 \mathrm{read}(5,10$, end $=999) \mathrm{t} i$, power, powden, $t d, \mathrm{~kg}, \mathrm{ppm}$, burnup

$c$ burnup in percent

burnup $=1.0 \mathrm{~d}-2$ *burnup

c calculate irradiation time and average neutron flux

time $=$ burnup $/(1.25 \mathrm{~d}-3 *$ powden $)$

if (ti.eq.0.0do) ti=time

$\mathrm{dm}=1.0 \mathrm{do}-0.5 \mathrm{do}$ *burnup

nflux $=2.952 \mathrm{~d} 13 *$ powden $/ \mathrm{dm}$

c write input data plus nflux write $(6,20)$

20 format ('Oinput: irrad time (d), power (MW), pow den (MW/kgU-235),

2decay time $(y), \cdot / 5 x, '$ asby mass $(\mathrm{kg}), \operatorname{Co-59}(\mathrm{ppm}), U-235$ burnup $(z)$

3 , avg flux $\left.(\mathrm{n} / \mathrm{cm} * * 2-\mathrm{s})^{\prime}\right)$

write $(6,11)$ ti, power, powden, $t d, k g, p p m$, burnup, nflux

$c$ use ti as a flag for additional printout

nskip $=0$

if $(t i .1 t .0 .0 \mathrm{do})$ then 


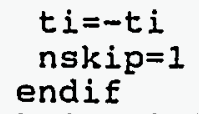

c check if ti is consistent ( $<1 \%)$ with burnup and power density if (dabs (ti/time - 1.0do).ge.1.0d-2) stop 101

c irradiation time $(t i)$ in days and decay time (td) in years $t i=t i * 8.64 \mathrm{~d} 4$ $t d=t d * 3.1536 d 7$

$c$ initialize arrays do $101 i=1,13$

$101 r(i)=0.0 \mathrm{do}$ do $103 i=1,5$ gsour $(i)=0.0 \mathrm{do}$ gflux $(i)=0.0 \mathrm{do}$

103 gdose $(i)=0.0 d 0$

c in subroutines, calculate nflux in 10 steps bu=burnup/10.0do

c \#1: $\operatorname{sr}-90$ time $=t i / 10.0 \mathrm{do}$

$r(1)=3.121 d 16 * y$ ield $(1) *$ power

$k(1)=d k(1)+\operatorname{cap}(1) * n f l u x$

c $\quad \mathrm{nO}(1)=\mathrm{r}(1) / \mathrm{k}(1) *(1.0 \mathrm{dO}-\operatorname{dexp}(-\mathrm{k}(1) * t i))$ cal1 srgo $n(1)=n 0(1) * d \exp (-d k(1) * t d)$

srate $(1)=d k(1) * n(1) * p h(1)$

srate $(2)=d k(1) * n(1) * \mathrm{ph}(2)$

drate $(1)=f 2 d(1) * \operatorname{srate}(1) * p f l u x$

drate $(2)=f 2 d(2) * \operatorname{srate}(2) * \mathrm{p} f l u x$

gsour (1)=gsour (1) + srate (1)

gsour $(2)=$ gsour $(2)+$ srate $(2)$

gflux $(1)=\operatorname{gflux}(1)+$ srate $(1) * p f l u x$

gflux (2) $=g f l u x(2)+\operatorname{srate}(2) * p f l u x$

gdose $(1)=$ gdose $(1)+$ drate $(1)$

c \#2: $y-90$ gdose $(2)=$ gdose $(2)+\operatorname{drate}(2)$

$k(2)=d k(2)+\operatorname{cap}(2) * n f l u x$

$\mathrm{nO}(2)=\mathrm{dk}(1) / \mathrm{k}(2) * \mathrm{nO}(1)$

if $(\mathrm{k}(2) * \mathrm{ti} .1 \mathrm{e} .4 .605170186 \mathrm{~d} 1) \mathrm{no}(2)=$ $x \operatorname{dk}(1) * r(1) / k(1) *((1.0 d 0-\operatorname{dexp}(-k(2) * t i)) / k(2)-$ $x(\operatorname{dexp}(-k(1) * t i)-\operatorname{dexp}(-k(2) * t i)) /(k(2)-k(1)))$ $\mathrm{n}(2)=\mathrm{dk}(1) / \mathrm{dk}(2) * \mathrm{n}(1)$

if $(\mathrm{dk}(2) *$ td. le.4.605170186d1) $\mathrm{n}(2)=$ $x \operatorname{dk}(1) * n o(1) *(\operatorname{dexp}(-d k(1) * t d)-\operatorname{dexp}(-d k(2) * t d)) /$

$x(d k(2)-d k(1))+n o(2) * d \exp (-d k(2) * t d)$

srate $(3)=d k(2) * n(2) * p h(3)$

srate $(4)=\mathrm{dk}(2) * \mathrm{n}(2) * \mathrm{ph}(4)$

srate $(5)=\mathrm{dk}(2) * \mathrm{n}(2) * \mathrm{ph}(5)$

drate $(3)=f 2 d(1) * \operatorname{srate}(3) * p f l u x$

drate $(4)=f 2 d(2) *$ srate $(4) *$ pflux

drate $(5)=f 2 d(3) *$ srate $(5) *$ pflux

gsour $(1)=$ gsour $(1)+\operatorname{srate}(3)$

gsour (2) =gsour (2) + srate (4)

gsour $(3)=$ gsour $(3)+\operatorname{srate}(5)$

gflux $(1)=g f l u x(1)+\operatorname{srate}(3) * \operatorname{pflux}$

gflux (2) $=$ gflux (2) + srate (4)*pflux

gflux (3) =gflux (3) + srate (5)*pflux

gdose $(1)=$ gdose $(1)+\operatorname{drate}(3)$

gdose $(2)=$ gdose $(2)+$ drate $(4)$

c \#3: $\operatorname{cs}-133$ gdose $(3)=$ gdose $(3)+$ drate $(5)$

$r(3)=3.121 d 16 * y$ ield $(3) *$ power

$k(3)=d k(3)+\operatorname{cap}(3) * n f l u x$

no $(3)=r(3) / k(3) *(1.0 d 0-\operatorname{dexp}(-k(3) * t i))$

c \#4: cs -134

$n(3)=n O(3) * d \exp (-d k(3) * t d)$ 


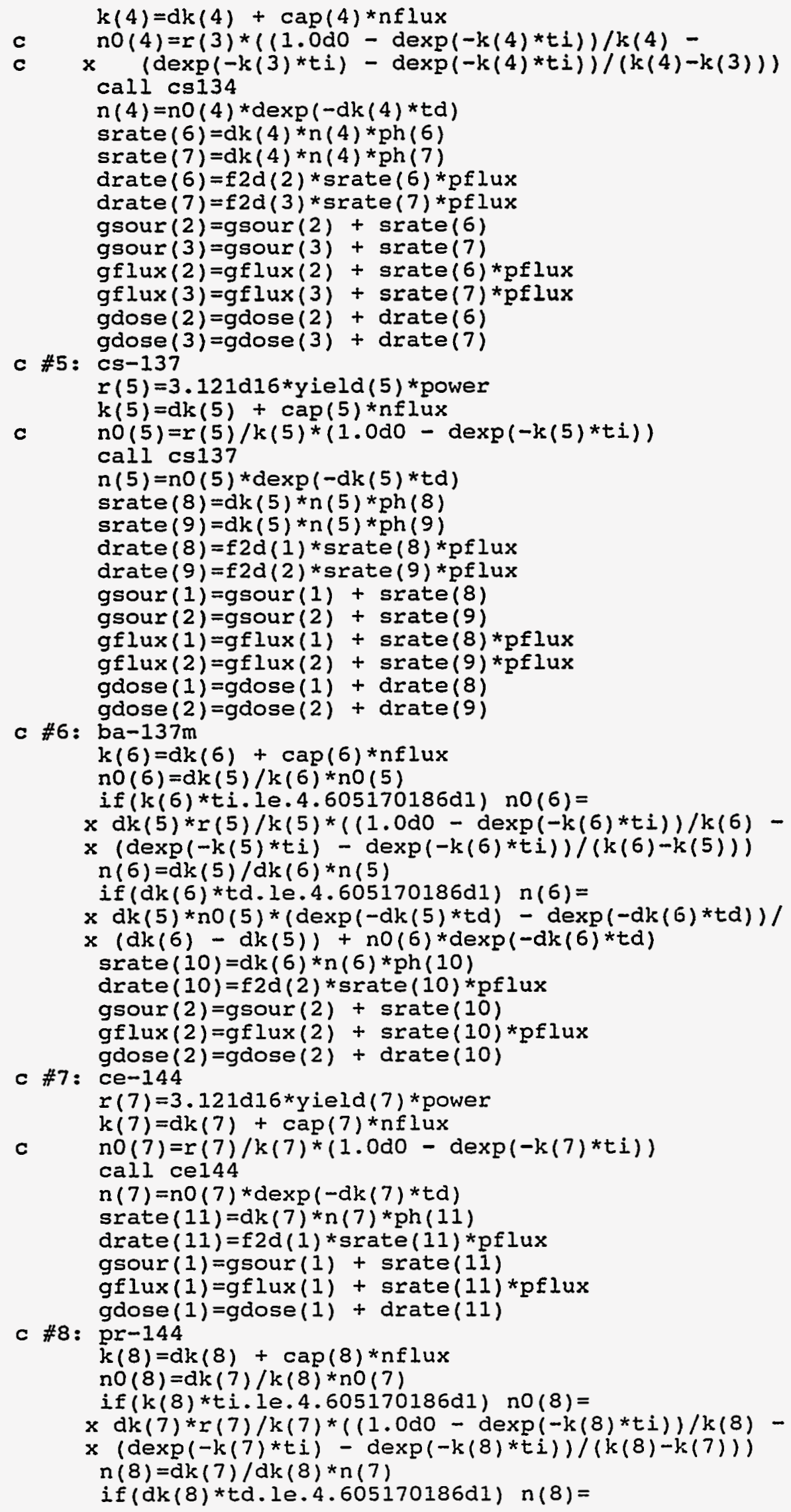


$x \operatorname{dk}(7) * n 0(7) *(\operatorname{dexp}(-d k(7) * t d)-\operatorname{dexp}(-d k(8) * t d)) /$

$x(d k(8)-d k(7))+n 0(8) * d \exp (-d k(8) * t d)$

srate $(12)=\mathrm{dk}(8) * \mathrm{n}(8) * \mathrm{ph}(12)$

srate $(13)=d k(8) * n(8) * \mathrm{ph}(13)$

srate $(14)=d k(8) * n(8) * \mathrm{ph}(14)$

drate $(12)=$ f $2 d(1) *$ srate $(12) *$ pflux

drate $(13)=f 2 d(2) *$ srate $(13) *$ pf lux

drate $(14)=f 2 d(3) *$ srate $(14) *$ pflux

gsour $(1)=$ gsour $(1)+$ srate (12)

gsour $(2)=$ gsour $(2)+$ srate $(13)$

gsour (3) =gsour (3) + srate (14)

gflux $(1)=\operatorname{gflux}(1)+\operatorname{srate}(12) * \mathrm{pflux}$

gflux $(2)=g f l u x(2)+\operatorname{srate}(13) *$ pflux

gflux $(3)=$ gflux $(3)+$ srate $(14) * p f l u x$

gdose $(1)=$ gdose $(1)+\operatorname{drate}(12)$

gdose $(2)=$ gdose $(2)+$ drate (13)

c \#9: ru-106

gdose $(3)=$ gdose $(3)+\operatorname{drate}(14)$

$r(9)=3.121 d 16 *$ yield $(9)$ *power

$k(9)=d k(9)+\operatorname{cap}(9) *$ nflux

c $n 0(9)=r(9) / k(9) *(1.0 d 0-\operatorname{dexp}(-k(9) * t i))$

call rulo6

$\mathrm{n}(9)=\mathrm{n} 0(9) * \operatorname{dexp}(-\mathrm{dk}(9) * t d)$

c \#10: $\mathrm{rh}-106$

$k(10)=\mathrm{dk}(10)+\operatorname{cap}(10) * \mathrm{nflux}$

$\mathrm{no}(10)=\mathrm{dk}(9) / k(10) * \mathrm{no}(9)$

if $(k(10) * t i .1 e .4 .605170186 \mathrm{~d} 1) \mathrm{no}(10)=$

$x \mathrm{dk}(9) * r(9) / k(9) *((1.0 \mathrm{do}-\operatorname{dexp}(-k(10) * t i)) / k(10)-$

$\times(\operatorname{dexp}(-k(9) * t i)-\operatorname{dexp}(-k(10) * t i)) /(k(10)-k(9)))$

$\mathrm{n}(10)=\mathrm{dk}(9) / \mathrm{dk}(10) * \mathrm{n}(9)$

if $(\mathrm{dk}(10) * \mathrm{td} .1 \mathrm{e} .4 .605170186 \mathrm{~d} 1) \mathrm{n}(10)=$

$x \operatorname{dk}(9) * n 0(9) *(\operatorname{dexp}(-d k(9) * t d)-\operatorname{dexp}(-d k(10) * t d)) /$

$x(d k(10)-d k(9))+n o(10) * d \exp (-d k(10) * t d)$

srate $(15)=\mathrm{dk}(10) * \mathrm{n}(10) * \mathrm{ph}(15)$

srate $(16)=\mathrm{dk}(10) * \mathrm{n}(10) * \mathrm{ph}(16)$

srate $(17)=\mathrm{dk}(10) * \mathrm{n}(10) * \mathrm{ph}(17)$

drate $(15)=f 2 d(1) *$ srate $(15) *$ pflux

drate $(16)=f 2 d(2) *$ srate $(16) * p$ flux

drate $(17)=f 2 d(3) *$ srate $(17) * p$ flux

gsour $(1)=$ gsour $(1)+$ srate $(15)$

gsour $(2)=$ gsour $(2)+$ srate $(16)$

gsour $(3)=$ gsour $(3)+\operatorname{srate}(17)$

gflux $(1)=g f l u x(1)+\operatorname{srate}(15) *$ pflux

gflux $(2)=g f l u x(2)+\operatorname{srate}(16) *$ pflux

gflux $(3)=\operatorname{gflux}(3)+\operatorname{srate}(17) *$ pflux

gdose $(1)=$ gdose $(1)+\operatorname{drate}(15)$

gdose (2)=gdose (2) + drate (16)

c \#11: $z r-95$

gdose $(3)=$ gdose $(3)+$ drate $(17)$

$r(11)=3.121 d 16 *$ yield $(11) *$ power

$k(11)=\mathrm{dk}(11)+\operatorname{cap}(11) * \mathrm{nflux}$

c $\mathrm{no}(11)=\mathrm{r}(11) / \mathrm{k}(11) *(1.0 \mathrm{do}-\operatorname{dexp}(-\mathrm{k}(11) * t i))$

call zr95

$n(11)=n 0(11) * \operatorname{dexp}(-\operatorname{dk}(11) * t d)$

srate $(18)=\mathrm{dk}(11) * \mathrm{n}(11) * \mathrm{ph}(18)$

drate $(18)=f 2 d(2) *$ srate $(18) * \mathrm{pflux}$

gsour $(2)=$ gsour $(2)+\operatorname{srate}(18)$

gflux $(2)=g f l u x(2)+\operatorname{srate}(18) *$ pflux

gdose $(2)=$ gdose $(2)+$ drate $(18)$

c \#12: $\mathrm{nb}-95$

$k(12)=d k(12)+\operatorname{cap}(12) * n f l u x$

$\mathrm{no}(12)=\mathrm{dk}(11) / \mathrm{k}(12) * \mathrm{no}(11)$

if $(k(12) *$ ti.le.4.605170186d1) no(12)=

$x \operatorname{dk}(11) * r(11) / k(11) *((1.0 d 0-\operatorname{dexp}(-k(12) * t i)) / k(12)-$

$x(\operatorname{dexp}(-k(11) * t i)-\operatorname{dexp}(-k(12) * t i)) /(k(12)-k(11)))$ 
$\mathrm{n}(12)=\mathrm{dk}(11) / \mathrm{dk}(12) * \mathrm{n}(11)$

if $(\mathrm{dk}(12) * t d .1 \mathrm{l} .4 .605170186 \mathrm{~d} 1) \mathrm{n}(12)=$

$x \operatorname{dk}(11) * n o(11) *(\operatorname{dexp}(-\operatorname{dk}(11) * t d)-\operatorname{dexp}(-d k(12) * t d)) /$

$x(d k(12)-d k(11))+n o(12) * d \exp (-d k(12) * t d)$

srate $(19)=\mathrm{dk}(12) * \mathrm{n}(12) * \mathrm{ph}(19)$

drate $(19)=$ f $2 d(2) * \operatorname{srate}(19) * \mathrm{pflux}$

gsour (2)=gsour (2) + srate (19)

gflux (2) $=g f \operatorname{lux}(2)+\operatorname{srate}(19) * p f l u x$

c \#13: $\operatorname{co-60}$

gdose $(2)=$ gdose $(2)+$ drate $(19)$

c $\mathrm{no}(13)=\mathrm{r}(13) / \mathrm{k}(13) *(1.0 \mathrm{do}-\operatorname{dexp}(-\mathrm{k}(13) * t i))$

call co60

$\mathrm{n}(13)=\mathrm{nO}(13) * \operatorname{dexp}(-\mathrm{dk}(13) * t d)$

srate $(20)=\operatorname{dk}(13) * \mathrm{n}(13) * \mathrm{ph}(20)$

drate $(20)=f 2 d(3) * \operatorname{srate}(20) * \mathrm{pflux}$

gsour (5) =srate (20)

gflux $(5)=$ srate $(20) * p f l u x$

gdose (5) =drate (20)

c sum fission product photon source and dose rates

sums $=0.0 \mathrm{dO}$

sumd $=0.0 \mathrm{dO}$

do $102 i=1,19$

sums=sums + srate $(i)$

102 sumd=sumd + drate $(i)$

burnup=power $/$ powden $* 1.0 \mathrm{~d} 3 *$ burnup

sums=sums / burnup

sumd=sumd/burnup

c mass of burned U-235 necessary for $100 \mathrm{rem} / \mathrm{h}$ dose rate sel $f=1.0 d 2 /$ sumd

c write output: $\mathrm{U}-235$ burned, $g$;

C FP source, ph/s per gU-235 burned; Co-60 source, ph/s;

c self-protected $\mathrm{U}-235$ mass burned, $g$

C FP dose, rem/h per gU-235 burned; co-60 dose, rem/h write $(6,21)$

21 format(" output: U-235 burned (g), FP source (ph/s per g), Co-60 s 2ource (ph/s),'/5x,'self-pro U-235 mass (g), FP dose (rem/h per g), 3 Co-60 dose (rem/h)')

write $(6,11)$ burnup, sums, srate (20), self, sumd, drate (20) if (nskip.eq.0) go to 100

c write optional data write $(6,22)$

22 format(" optional: form \& loss rates (atoms/s), initial \& current 2no. (atoms), '/5x'source (ph/s), flux (ph/cm**2-s), dose (rem/h)')

c formation rates, atoms/s write $(6,11) \mathbf{r}$

c loss rates, atoms/s write $(6,11) \mathrm{k}$

c atoms initially present, atoms (time=ti) write $(6,11)$ no

c atoms currently present, atoms (time=td) write $(6,11) \mathrm{n}$

c photon source rates, ph/s write $(6,11)$ srate

c photon source rates, ph/s; sum fission product photon source do $106 \quad i=1,3$

106 gsour $(4)=$ gsour $(4)+$ gsour $(i)$ write $(6,11)$ gsour

c photon fluxes, $\mathrm{ph} / \mathrm{cm}^{* * 2-s ;}$ sum fission product photon fluxes do $107 i=1,3$

$107 \mathrm{gflux}(4)=\mathrm{gflux}(4)+\mathrm{gflux}(i)$ write $(6,11)$ gflux

c photon dose rates, rem/h write $(6,11)$ drate 
c photon dose rates, rem/h; sum fission product photon dose do $108 i=1,3$

108 gdose $(4)=$ gdose $(4)+$ gdose $(i)$ write $(6,11)$ gdose go to 100

999 stop end

C

subroutine sr90

real*8 dk(13), cap (13),r(13), no(13)

real $* 8$ powden, $\mathrm{kg}, \mathrm{ppm}$

real $* 8$ bu, time, dm, nflux, $t(10), c(10), n(10), k$

common dk, cap, $r, \mathrm{no}$, powden, $\mathrm{kg}, \mathrm{ppm}, \mathrm{bu}, t$ ime

do $101 i=1,10$

$t(i)=\operatorname{dfloat}(i) * t i m e$

$\mathrm{dm}=1.0 \mathrm{do}-\mathrm{bu} *(\mathrm{dfl}$ loat $(i)-0.5 \mathrm{do})$

nflux $=2.952 \mathrm{~d} 13 *$ powden $/ \mathrm{dm}$

$k=d k(1)+\operatorname{cap}(1) * n f l u x$

if (i.eq.1) $c(1)=-r(1) / k$

if $(i . n e .1) \quad c(i)=n(i-1) * \operatorname{dexp}(k * t(i-1))-r(1) * \operatorname{dexp}(k * t(i-1)) / k$

c

$101 n(i)=r(1) / k+c(i) * \operatorname{dexp}(-k * t(i))$

write $(6,11) \mathrm{n}$

11 format $(1 \mathrm{x}, 1 \mathrm{p} 6 \mathrm{~d} 12.5)$

$n O(1)=n(10)$

return

c

end

subroutine $\operatorname{cs} 134$

real*8 dk(13), cap (13), r(13), no(13)

real $* 8$ powden, $\mathrm{kg}, \mathrm{ppm}$

real $* 8$ bu, time, dm, nflux, $t(10), c(10), n(10), k 1, k 2$, del

common $\mathrm{dk}, \mathrm{cap}, r, \mathrm{no}$, powden, $\mathrm{kg}, \mathrm{ppm}, \mathrm{bu}, \mathrm{time}$

do $101 i=1,10$

$t(i)=\operatorname{dfloat}(i) * t$ ime

$\mathrm{dm}=1.0 \mathrm{do}-\mathrm{bu} *(\mathrm{dfloat}(\mathrm{i})-0.5 \mathrm{do})$

nflux $=2.952 \mathrm{~d} 13 *$ powden $/ \mathrm{dm}$

$k 1=d k(3)+\operatorname{cap}(3) * n f l u x$

$k 2=d k(4)+c a p(4) * n f l u x$

del $=\mathrm{k} 2-\mathrm{k} 1$

if $($ i.eq. 1$) \quad c(1)=r(3) *(-1.0 \mathrm{do} / \mathrm{k} 2+1.0 \mathrm{do} / \mathrm{del})$

if $(i . n e .1) \quad c(i)=n(i-1) * \operatorname{dexp}(k 2 * t(i-1))-$

$x r(3) *(\operatorname{dexp}(k 2 * t(i-1)) / k 2-\operatorname{dexp}(\operatorname{del} * t(i-1)) / \operatorname{del})$

c

$101 \mathrm{n}(i)=r(3) *(1.0 \mathrm{do} / \mathrm{k} 2-\operatorname{dexp}(-k 1 * t(i)) / \operatorname{del})+c(i) * \operatorname{dexp}(-k 2 * t(i))$

write $(6,11) \mathrm{n}$

11 format (1x,1p6d12.5)

$\mathrm{no}(4)=\mathrm{n}(10)$

return

c

end

subroutine $\operatorname{cs} 137$

real*8 dk(13), cap(13), r(13), no(13)

real $* 8$ powden, $\mathrm{kg}, \mathrm{ppm}$

real $* 8$ bu, time, dm, nflux, $t(10), c(10), n(10), k$

common dk, cap, $r, \mathrm{no}$, powden, $\mathrm{kg}, \mathrm{ppm}, \mathrm{bu}, \mathrm{time}$

do $101 i=1,10$

$t(i)=\operatorname{dfloat}(i) * t i m e$

$\mathrm{dm}=1.0 \mathrm{dO}-\mathrm{bu} *(\mathrm{dfl}$ loat $(\mathrm{i})-0.5 \mathrm{do})$

nflux $=2.952 \mathrm{~d} 13 *$ powden $/ \mathrm{dm}$

$k=d k(5)+\operatorname{cap}(5) * n f l u x$

if (i.eq.1) $c(1)=-r(5) / k$

if (i.ne.1) $c(i)=n(i-1) * \operatorname{dexp}(k * t(i-1))-r(5) * \operatorname{dexp}(k * t(i-1)) / k$

c

$101 n(i)=r(5) / k+c(i) * \operatorname{dexp}(-k * t(i))$

write $(6,11) \mathrm{n}$

11 format (1x,1p6d12.5)

$n O(5)=n(10)$ 
return

c

end

subroutine cel44

real*8 dk(13), cap (13),r(13), no(13)

real*8 powden, $\mathrm{kg}, \mathrm{ppm}$

real*8 bu, time, dm, nflux, $t(10), c(10), n(10), k$

common dk, cap, $r, \mathrm{no}$, powden, $\mathrm{kg}, \mathrm{ppm}, \mathrm{bu}, t$ ime

do $101 i=1,10$

$t(i)=\operatorname{dfloat}(i) * t i m e$

$\mathrm{dm}=1.0 \mathrm{do}-\mathrm{bu} *(\mathrm{dfloat}(\mathrm{i})-0.5 \mathrm{~d} 0)$

nflux $=2.952 \mathrm{~d} 13 *$ powden $/ \mathrm{dm}$

$k=\mathrm{dk}(7)+\operatorname{cap}(7) * \mathrm{nflux}$

if (i.eq.1) $c(1)=-r(7) / k$

if $(i . n e .1) \quad c(i)=n(i-1) * \operatorname{dexp}(k * t(i-1))-r(7) * \operatorname{dexp}(k * t(i-1)) / k$

c

101

$n(i)=r(7) / k+c(i) * \operatorname{dexp}(-k * t(i))$

write $(6,11)$ n

11 format (1x,1p6d12.5)

$\mathrm{no}(7)=\mathrm{n}(10)$

return

end

c

subroutine ru106

real*8 dk(13), cap (13), r(13), no(13)

real $* 8$ powden, $\mathrm{kg}, \mathrm{ppm}$

real * 8 bu, time, dm, nflux, $t(10), c(10), n(10), k$

common $\mathrm{dk}$, cap, $r, n 0$, powden, $\mathrm{kg}, \mathrm{ppm}, \mathrm{bu}, t i m e$

do $101 i=1,10$

$t(i)=\operatorname{dfloat}(i) * t i m e$

$\mathrm{dm}=1.0 \mathrm{do}-\mathrm{bu} *($ dfloat (i) $-0.5 \mathrm{do})$

nflux $=2.952 \mathrm{~d} 13 *$ powden $/ \mathrm{dm}$

$k=d k(9)+\operatorname{cap}(9) * n f l u x$

if (i.eq.1) $c(1)=-r(9) / k$

if $(i, n e .1) \quad c(i)=n(i-1) * \operatorname{dexp}(k * t(i-1))-r(9) * \operatorname{dexp}(k * t(i-1)) / k$

$n(i)=r(9) / k+c(i) * \operatorname{dexp}(-k * t(i))$

c

write $(6,11) \mathrm{n}$

11 format (1x,1p6d12.5)

$\mathrm{no}(9)=\mathrm{n}(10)$

return

end

$c$

subroutine zrg5

real*8 dk(13), cap (13), r(13), no(13)

real*8 powden, $\mathrm{kg}, \mathrm{ppm}$

real $* 8$ bu, time, dm, nflux, $t(10), c(10), n(10), k$

common $\mathrm{dk}$, cap $, r, \mathrm{no}$, powden, $\mathrm{kg}, \mathrm{ppm}, \mathrm{bu}, \mathrm{time}$

do $101 i=1,10$

$t(i)=\operatorname{deloat}(i) * t i m e$

$\mathrm{dm}=1.0 \mathrm{do}-\mathrm{bu} *(\mathrm{df} l o a t(i)-0.5 \mathrm{do})$

nflux=2.952d13*powden $/ \mathrm{dm}$

$\mathrm{k}=\mathrm{dk}(11)+\operatorname{cap}(11) * \mathrm{nflux}$

if (i.eq.1) $c(1)=-r(11) / \mathrm{k}$

if $(i . n e .1) \quad c(i)=n(i-1) * \operatorname{dexp}(k * t(i-1))-r(11) * \operatorname{dexp}(k * t(i-1)) / k$

$101 \mathrm{n}(\mathrm{i})=r(11) / \mathrm{k}+\mathrm{c}(\mathrm{i}) * \operatorname{dexp}(-\mathrm{k} * t(i))$

c

write $(6,11) n$

11 format (1x,1p6d12.5)

$\mathrm{no}(11)=\mathrm{n}(10)$

return

$c$

end

subroutine co60

real*8 dk(13), cap (13), r(13), no(13)

real $* 8$ powden, $\mathrm{kg}, \mathrm{ppm}$

real*8 bu, time, dm, nflux, $t(10), c(10), n(10), k 1, k 2, r 59$

common $\mathrm{dk}, \mathrm{cap}, r, \mathrm{no}$, powden, $\mathrm{kg}, \mathrm{ppm}, \mathrm{bu}, t i m e$ 
do $101 i=1,10$

$t(i)=\operatorname{deloat}(i) * t i m e$

$\mathrm{dm}=1.0 \mathrm{do}-\mathrm{bu} *(\mathrm{dfloat}(\mathrm{i})-0.5 \mathrm{do})$

nflux $=2.952 \mathrm{~d} 13 *$ powden $/ \mathrm{dm}$

$k 1=\quad 39.67 d-24 * n f l u x$

$k 2=\operatorname{dk}(13)+\operatorname{cap}(13) * n f l u x$

$\mathrm{r} 59=1.022 \mathrm{~d} 19 * \mathrm{~kg} * \mathrm{ppm} * \mathrm{k} 1$

if (i.eq.1) $c(1)=-r 59 / \mathrm{k} 2$

if (i.ne.1) $c(i)=n(i-1) * \operatorname{dexp}(k 2 * t(i-1))-r 59 * \operatorname{dexp}(k 2 * t(i-1)) / k 2$

$101 \mathrm{n}(\mathrm{i})=r 59 / \mathrm{k} 2+c(i) * \operatorname{dexp}(-\mathrm{k} 2 * t(i))$

write $(6,11) n$

11 format (1x, 1p6d12.5)

$\mathrm{no}(13)=\mathrm{n}(10)$

return

end 